UNIVERSIDADE DE BRASÍLIA - UnB

FACULDADE DE TECNOLOGIA

DEPARTAMENTO DE ENGENHARIA MECÂNICA

PROGRAMA DE PÓS-GRADUAÇÃO EM SISTEMAS MECATRÔNICOS

MAYRA BATISTA CORRÊA

UMA METODOLOGIA PARA O PROJETO DE INTERFACES HOMEM-MÁQUINA ORIENTADO A PESSOAS COM DEFICIÊNCIA VISUAL, NO CONTEXTO DE AMBIENTES DOMÓTICOS

BRASÍLIA 
UNIVERSIDADE DE BRASÍLIA - UnB

FACULDADE DE TECNOLOGIA

DEPARTAMENTO DE ENGENHARIA MECÂNICA

PROGRAMA DE PÓS-GRADUAÇÃO EM SISTEMAS MECATRÔNICOS

\title{
UMA METODOLOGIA PARA O PROJETO DE INTERFACES HOMEM-MÁQUINA ORIENTADO A PESSOAS COM DEFICIÊNCIA VISUAL, NO CONTEXTO DE AMBIENTES DOMÓTICOS
}

\begin{abstract}
Dissertação apresentada ao Departamento de Engenharia Mecânica da Faculdade de Tecnologia da Universidade de Brasília como parte dos requisitos necessários para obtenção do grau de Mestre em Sistemas Mecatrônicos
\end{abstract}

Orientador: Prof. Dr. Carlos Humberto Llanos Quintero

Co-orientador: Prof. ${ }^{a}$ Dr. Ivette Kafure Munoz 


\title{
FOLHA DE APROVAÇÃO
}

\author{
MAYRA BATISTA CORRÊA
}

UMA METODOLOGIA PARA O PROJETO DE INTERFACES HOMEM-MÁQUINA ORIENTADO A PESSOAS COM DEFICIÊNCIA VISUAL, NO CONTEXTO DE AMBIENTES DOMÓTICOS

Dissertação apresentada ao Departamento de Engenharia Mecânica da Faculdade de Tecnologia da Universidade de Brasília, como requisito para a obtenção do título de Mestre em Sistemas Mecatrônicos.

Aprovada em:

Prof. Dr. Carlos Humberto Llanos UNIVERSIDADE DE BRASÍLIA - UnB

Dra. Candice Aparecida Rodrigues Assunção (INEP) INSTITUTO NACIONAL DE ESTUDOS E PESQUISAS EDUCACIONAIS ANÍSIO TEIXEIRA- INEP

Prof. Dr. Paulo Roberto de Lira Gondim UNIVERSIDADE DE BRASÍLIA - UnB 
Agradeço a Deus que meu deu mais esta oportunidade, aos meus pais, amigos e familiares pela paciência e apoio incondicional.

Aos Professores: Carlos H. Llanos, Ivette Kafure e Patrícia Rapozo pela confiança que depositaram em mim, mesmo nos dias mais difíceis.

Aos amigos: Klaus Lacerda, Rômulo Eduardo e Wilse Cristina. 
"Só se vê bem com o coração, o essencial é invisível aos olhos." Antoine de Saint-Exupéry 


\section{RESUMO}

Este trabalho apresenta um procedimento metodológico, objetivando o desenvolvimento de uma interface homem-computador dentro de um ambiente residencial, especialmente voltada para pessoas com deficiência visual, a qual foi extensivamente analisada e testada com 21 pessoas que apresentam Deficiência Visual (PDV). A metodologia aqui exposta poderia ser avaliada com usuários com deficiência motora e múltipla, com as devidas adaptações e de acordo com o perfil do usuário e tipo de deficiência. $\mathrm{O}$ foco deste trabalho é possibilitar a acessibilidade domótica, indo ao encontro das leis, normas e diretrizes no que diz respeito à acessibilidade. Para atingir esse objetivo buscou-se possibilitar o domínio funcional da própria casa, da pessoa com deficiência, realizando assim um projeto acessível de automação residencial. Como um passo metodológico no desenvolvimento da interface domótica foram propostos pré-testes com usuários, que durante a execução evidenciaram que os módulos de acessibilidade e o Touch Screen nos dispositivos móveis são ferramentas muito úteis às PDV, total ou parcial, guiando este trabalho a produzir um subproduto, testado e funcional: uma interface homem-computador em dispositivos móveis com sistema operacional Android para ambientes domóticos. Esta interface está disponível para uso, melhorias e alterações de forma livre. Para o projeto da interface sugerida foram considerados conceitos tais como design universal e emocional voltados para as experiências e percepções do usuário final, que utilizará o sistema de automação residencial. O trabalho também apresenta uma extensa revisão literária, que também incluí e apresenta as leis que regem a acessibilidade no Brasil, servindo de suporte para o desenvolvimento de novos trabalhos de sistemas tão necessários nos dias de hoje, em que a comunidade com deficiência visual representa quase $30 \%$ da população total brasileira. Ao término deste trabalho foi possível o desenvolvimento de uma interface homem-máquina de controle e acionamento de ambientes domóticos para pessoas com deficiência visual assim como, verificada a importância do usuário no processo de análise, criação e finalização da interface a fim de atender as normas e diretrizes do W3C nos quesitos de acessibilidade e usabilidade.

Palavras-chave: Acessibilidade, interfaces, automação residencial, usuário com deficiência visual. 


\begin{abstract}
This work presents a methodological approach, aiming at the development of a human-computer interface within a residential setting. The latter, especially toward people with visual disabilities, was extensively analyzed and tested with 21 people with Visual Impairment (PDV). The methodology outlined here could be evaluated with users with physical and multiple disabilities, in accordance with the user adaptations profile and type of disability. The focus of this work is to enable home automation accessibility, meeting the laws, regulations and guidelines regarding accessibility. To achieve this goal we sought to enable the functional domain of a home of the disabled person, thus realizing an affordable home automation project. As a methodological step in the development of home automation interface was proposed pre-user testing, that during the execution showed that the accessibility of modules and the touch screen on mobile devices are very useful tools for PDV, total or partial, guiding this work to produce a by-product, tested and functional: A human-computer interface on mobile devices with Android operating system for home automation environments. This interface is available for use, improvements and freeform changes. For the suggested interface design were considered concepts such as universal and emotional design focused on experiences and perceptions of the end user that will use the home automation system. The work also has an extensive literature review, which also included and features the laws governing accessibility in Brazil, serving as support for the development of new systems work so necessary today, where the visually impaired community is almost $30 \%$ of Brazil's total population. At the end of this work it was possible to implant a control man-machine interface and drive home automation environments for visually impaired people as well as verified the importance of the user in the process of analysis, creation and completion of the interface in order to meet the standards and guidelines of the $\mathrm{W} 3 \mathrm{C}$ in questions of accessibility and usability.
\end{abstract}

Keywords: Accessibility, interfaces, home automation, visually impaired user. 


\section{LISTA DE GRÁFICOS}

Gráfico - 4-1 - Porcentagem de UDV totais ou parciais que participaram dos pré-testes do CEEDV 103

Gráfico - 4-2 - Distribuição das idades dos deficientes visuais do CEEDV ........................ 103

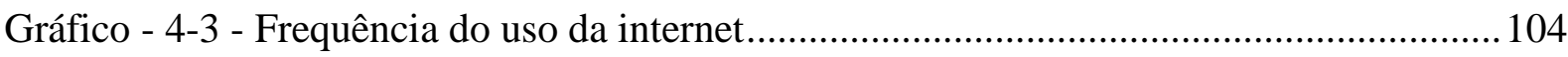

Gráfico - 4-4 - Nível de Conhecimento no uso do computador/dispositivos móveis............ 105

Gráfico - 4-5 Conhecimento relativo do uso do computador/dispositivos móveis pelo usuário. 105

Gráfico - 4-6 - Porcentagem de deficientes que trabalham................................................ 106

Gráfico - 4-7 - Frequência do uso da internet...................................................................... 106

Gráfico - 4-8 - Relação de trabalho e Casa própria .............................................................. 107

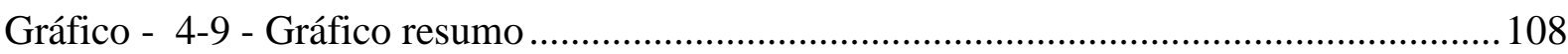

Gráfico - 4-10 - Usuários que conseguiram finalizar a tarefa. ........................................... 109 


\section{LISTA DE FIGURAS}

Figura 1-1- Relações entre IHC, Domótica e Acessibilidade.

Figura 1-2 - Comunicação dos elementos básicos de uma automação residencial/predial (FONTE: adaptado de: CASADOMO, 2010)

Figura 2-1- Relação entre computação pervasiva e computação ubíqua (FONTE: Adaptado

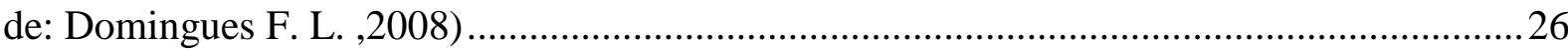

Figura 2-2 - Arquitetura utilizando Android (Adaptada de: MORIMOTO, 2009) ................. 45

Figura 2-3 - Placa Microcontrolada Arduino 2560 com Módulo Ethernet. 47

Figura 2-4 - O Processo de Interação Homem - Computador (Adaptada de PRATES.

Barbosa, 2003). 50

Figura 2-5 - Disciplinas que contribuem em IHC (adaptada de: ROCHA, 2000)...................52

Figura 2-6 - Níveis de processamento da informação (adaptada de NORMAN, 2004)...........55

Figura 2-7 - Diagrama Correlacionando IHM Acessíveis e Convencionais 59

Figura 2-8 - Níveis da pirâmide de automação (Adaptada de: www.mecatronicaatual.com.br).

Figura 3-1- Informações Estatísticas (FONTE: IBGE) 64

Figura 3-2 - Gráfico dos Diferentes Graus de Deficiência Visual (FONTE: CENSO 2010)...65

Fluxograma 3-1 - Atividades a realizar. . .66

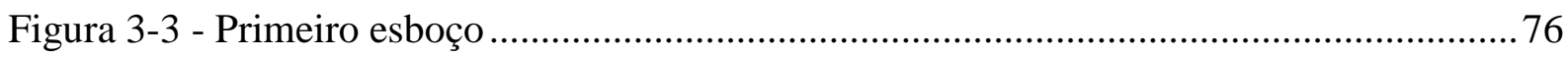

Figura 3-4 - Tela inicial - Segundo Esboço .................................................................... 76

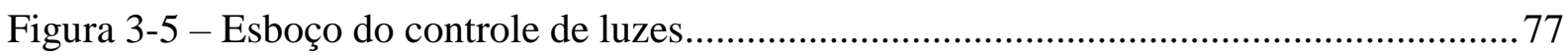

Figura 3-6 - Ferramenta de simulação de interface - JUSTINMIND. Escolha do protótipo,

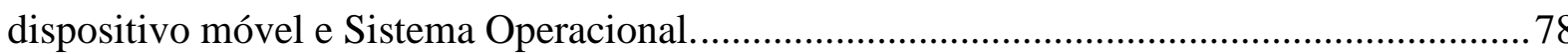

Figura 3-7 - Escolha das configurações básicas de forma...................................................... 78

Figura 3-8 - Processando as bibliotecas necessárias para a criação do protótipo .....................78

Figura 3-9 - Criação do primeiro Protótipo em branco. ............................................................ 78

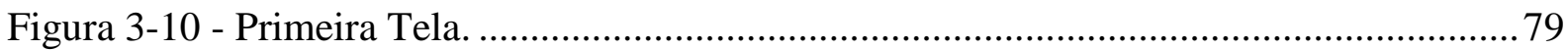


Figura 3-11 - Simulação da primeira tela gerada no navegador de preferência da pesquisadora.

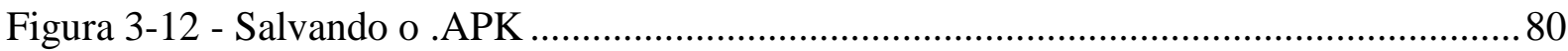

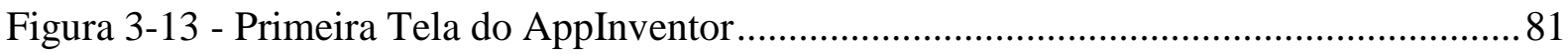

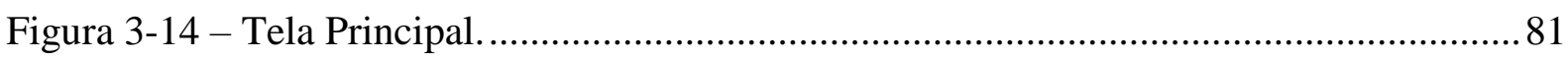

Figura 3-15 - Blocos de programação no App Inventor....................................................... 82

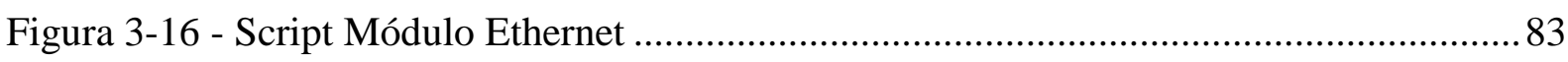

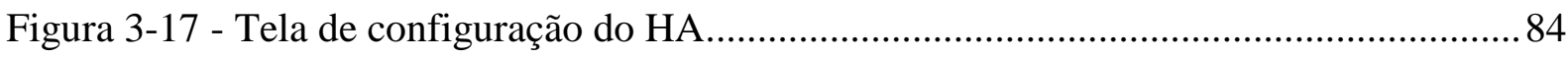

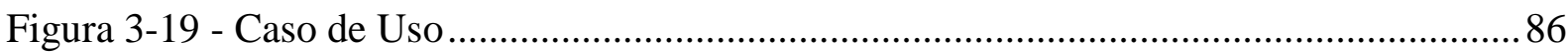

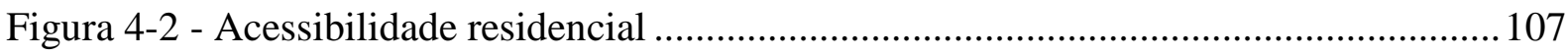

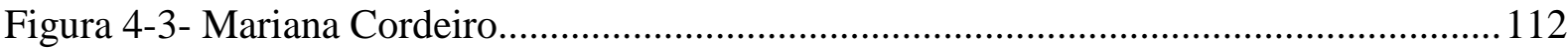

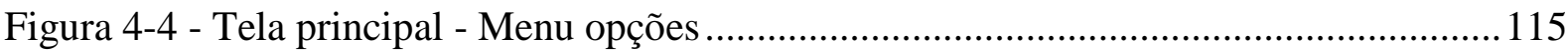

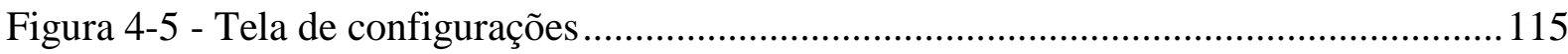

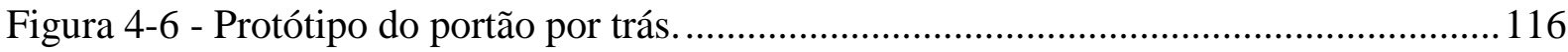

Figura 4-7 - Protótipo do portão pela frente...................................................................... 116

Figura 4-8 - Vista superior do protótipo - Casa composta por uma placa com 4 relés ..........116

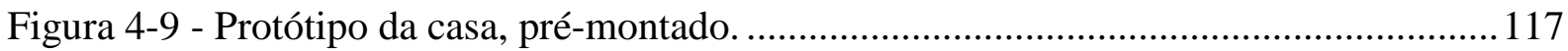

Figura 4-10 - Vista frontal do protótipo. Casa com 4 lâmpadas de led, sendo duas na parte

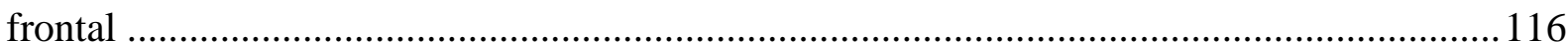

Figura 4-11- Central de automação composta por Arduino MEGA e Shield ETHERNET..117

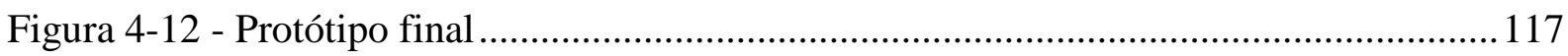

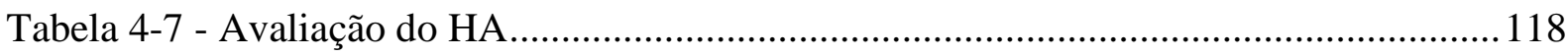




\section{LISTA DE TABELAS}

Tabela 2-1 - Métodos para o estudo do usuário (Adaptado de CUNHA, 1982). 32

Tabela 2-2 - Tabela de comparação das tecnologias (adaptada de Lugli e Sobrinho). 43

Tabela 2-3 - Parâmetros específicos entre cliente Android e o servidor de automação residencial (Adaptada de EUZÉBIO, 2011). 44

Tabela 2-4 - Sensores típicos para o setor residencial e suas aplicações 48

Tabela 3-1 - Tabela relacional: Grau de deficiência X Renda 65

Tabela 3-2 - Definição dos cenários 68

Tabela 3-3 - Métodos e Tarefas de cada cenário a serem realizados nos Pré-testes. 69

Tabela 3-4 - Etapas dos Pré-testes com os usuários deficientes visuais. 72

Tabela 3-5 - Descrição dos cenários e das tarefas que serão realizadas nos pré-testes com deficientes visuais 73

Tabela 4-1 - Média das idades dos alunos 95

Tabela 4-2 - Uso de dispositivos de entrada/saída .95

Tabela 4-3 - Observação entre os cenários 96

Tabela 4-4 - Persona João, usuário sem deficiência visual. 100

Tabela 4-5 - Tabela quantitativo de pessoas que moram com outros deficientes visuais ...... 108

Tabela 4-6 - Persona Mariana, UDV total. 112 


\section{LISTA DE ABREVIATURAS E SIGLAS}

ABDV - Associação dos Deficientes Visuais de Brasília.

AFB - American Foundation for Blind (Fundação Americana para Cegos).

API - Application Programming Interface (Interface de Programação de Aplicações).

CAN - Controller Area Network (Área de Controle de Rede).

CEBus - Consumer Electronics Bus (Barramento de Consumo Eletrônico).

CEEDV - Centro de Ensino Especial de Deficientes Visuais.

CSMA/CD - Carrier Sense Multiple Access with Collision Detection (Sistema de Gerenciamento de Tráfego).

DIs - Dispositivos Inteligentes.

EIA - Associação das Indústrias de Eletrônica.

ET - Evento de Topo.

FFD - Full-Function Devices (Dispositivo de Função Completa).

FPGAs - Field Programmable Gate Array ( Arranjo de Portas Programável em Campo).

FTA - Fault Tree Analysis (Análise da Árvore de Falhas).

$\mathrm{GHz}$ - (Gigahertz).

GPS - Global Positioning System (Sistema de posicionamento global).

HA - Home Affordable (Casa acessível).

HTML - Hyper Text Markup Language (Linguagem de marcação de hipertexto).

HTTP - Hypertext Transfer Protocol (Protocolo de Transferência de Hipertexto).

HTTPS - Hypertext Transfer Protocol Secure (Protocolo de transferência seguro de hipertexto).

IBGE - Instituto Brasileiro de Geografia e Estatística. 
IDS - Sistemas de Detecção de Intrusão.

IEEE - Institute of Electrical and Electronics Engineers.

IHC - Interface Homem Computador.

IHM - Interação Homem Máquina.

IMUs - Inertial Measurement Units (Unidades de medição inercial).

IP - Internet Protocol (Protocolo de internet).

ITS - Instituto de Tecnologia Social.

LISA - Library and Information Science Abstracts ( Biblioteca e resumos da Ciência da Informação).

MAC - Media Access Control (Controle de acesso de mídia).

MIMO - Multiple Input Multiple Output (Múltiplas Entradas Múltiplas Saídas).

MIT - Instituto de Tecnologia de Massachusetts.

NRZ - Non Return to Zero (Não Retorna Zero).

NVDA - Non Visual Desktop Access (Área de trabalho Sem Acesso Visual).

ONU - Organização das Nações Unidas.

OSI - Open Systems Interconnection (Interconexão de Sistemas Abertos).

PDP - Processo de Desenvolvimento de Produto.

PDV - Pessoas que apresentam Deficiência Visual.

PLC - Power Line Carrier (Linha de transmição de Energia).

PPNE - Programa de Apoio as Pessoas com Necessidades Especiais/UnB.

RFD - Reduced-Function Devices (Função Reduzida de Dispositivos).

RFIDs - Radio-Frequency Identification (Identificação de Rádio Frequencia).

SAR - Servidor de Automação Residencial.

SSC - Spread Spectrum Carrier (Transportador Espalhado de Spectrum).

TCLE - Termo de Consentimento Livre e Esclarecido. 
UDV - Usuários com Deficiência Visual.

UML - Unified Modeling Language (Linguagem de Modelagem Unificada).

UnB - Universidade de Brasília.

Wi-Fi - Wireless Fidelity (Fidelidade sem fio).

WLAN - Wireless Local Area Network (Rede Sem Fio de Área Local). 


\section{SUMÁRIO}

LISTA DE GRÁFICOS. viii

LISTA DE FIGURAS ix

LISTA DE TABELAS xi

LISTA DE ABREVIATURAS E SIGLAS xii

1. INTRODUÇÃO 19

1.1. Contextualização 19

1.2. Acessibilidade, Domótica e Interface (o tema desse trabalho) 20

1.3. Objetivo geral e objetivos específicos 22

1.4

Contribuições esperadas 23

1.5. Organização do trabalho 23

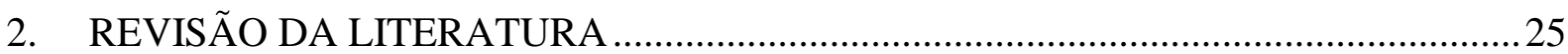

2.1. Aspectos sobre a evolução da computação pervasiva ..................................25

2.1.1. Aspectos sobre Interface e sua aplicação em Domótica............................26

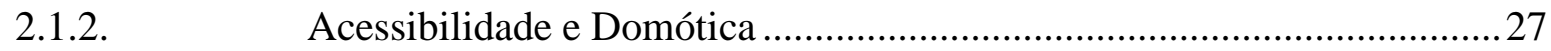

2.2. Conceitos básicos sobre projeto de Interfaces, Acessibilidade e Domótica. 28

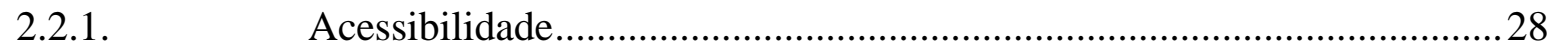

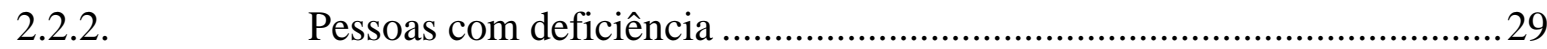

2.2.3. Conceitos básicos sobre Automação Residencial (Domótica) .................. 32

2.2.4. Aspectos de Segurança: o método de Árvore de Falhas............................34

2.2.5. Aspectos de comunicação na domótica ................................................. 35

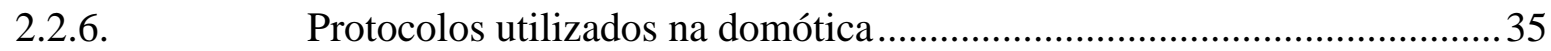

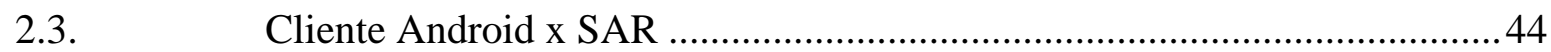

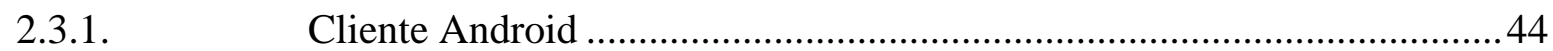

2.3.2. SAR - Servidor de Automação Residencial .......................................... 46

2.3.3. Questões a respeito da segurança da aplicação .....................................47 
2.4. Ferramenta de desenvolvimento parcialmente reconfigurável. 49

2.5. Aspectos sobre Interfaces x Interação 50

2.5.1. Design para usuários com deficiência visual...........................................52

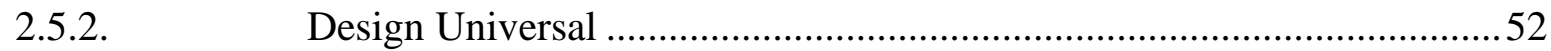

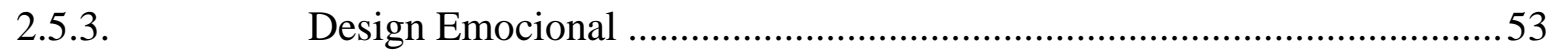

2.6. Aspectos sobre o tema de métodos e pesquisa científica no contexto desse trabalho .56

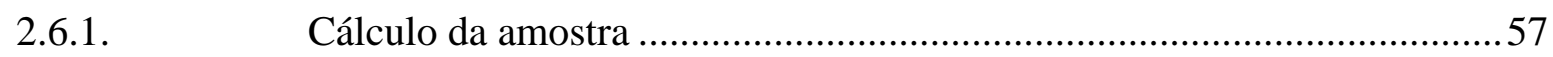

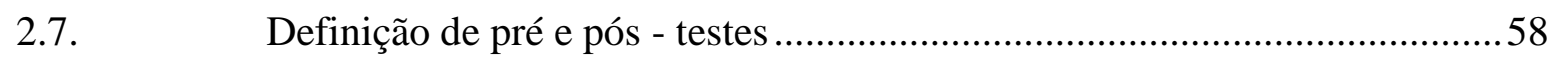

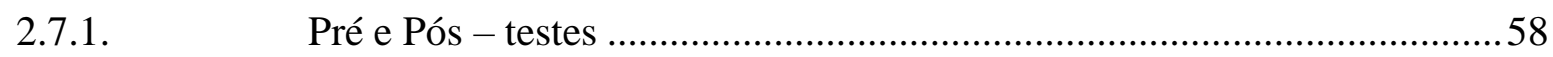

2.7.2. Modelos de Domótica de acordo com o nível de automação ....................60

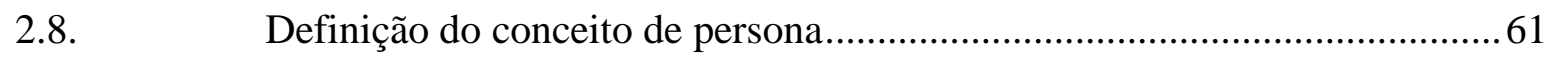

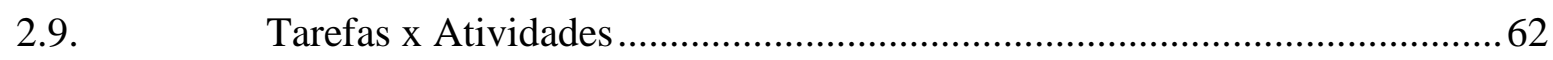

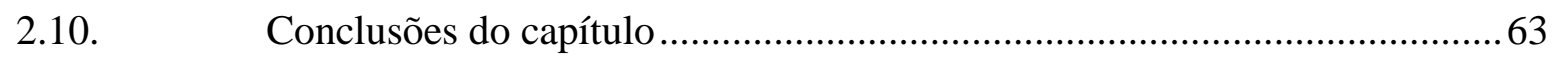

3. ASPECTOS METODOLÓGICOS E O PROJETO DA INTERFACE HOMEM

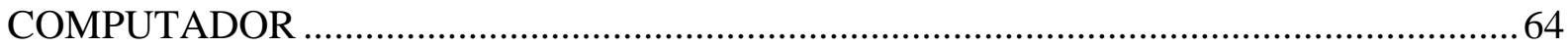

3.1. $\quad$ Análise e delimitação do espaço amostral a ser estudado .............................. 64

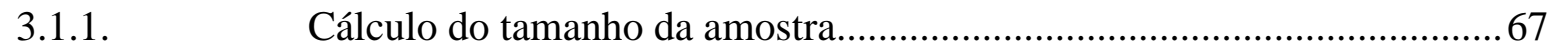

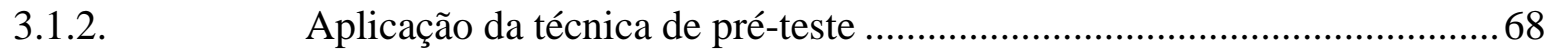

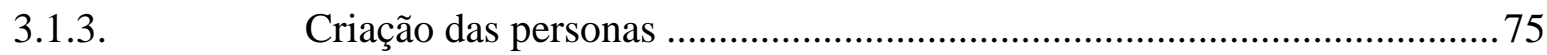

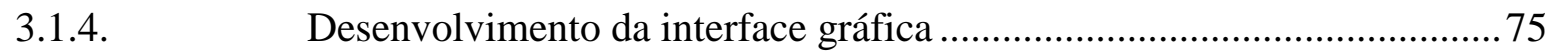

3.1.5. Criação do aplicativo para dispositivo móvel com Sistema Operacional Android para automação residencial com acessibilidade............................................. 80

3.1.6. Montagem da central de aplicação e fase de teste entre a central e o

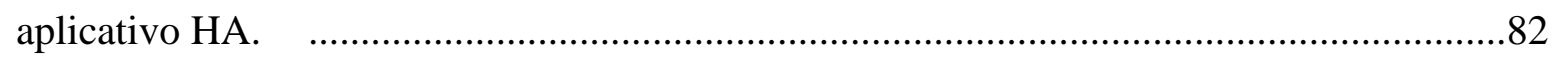

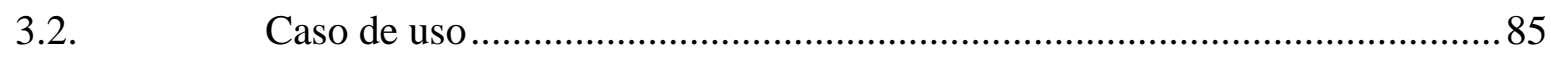

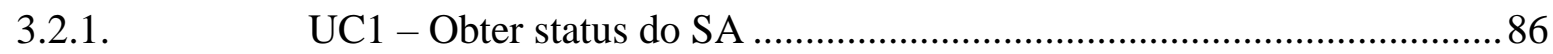

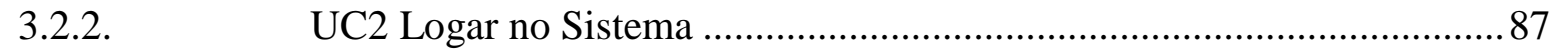




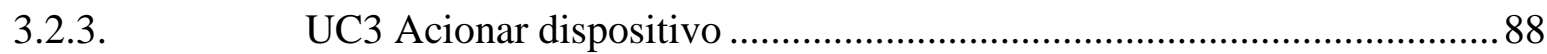

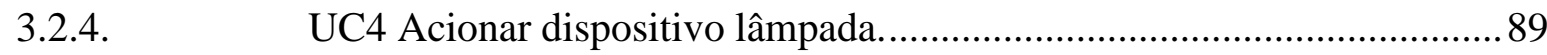

3.2.5. UC5 Acionar dispositivo portão...................................................... 90

3.2.6. UC6 Acionar dispositivo - lâmpada/portão, por voz...............................91

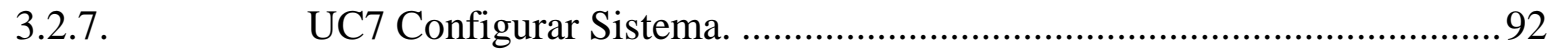

3.2.8. UC8 Mais Configurações. ................................................................. 93

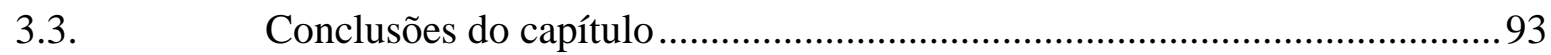

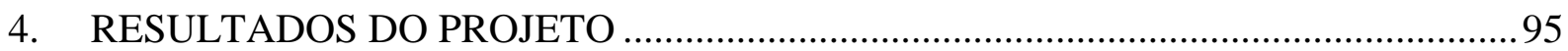

4.1. Resultados alcançados durante os pré-testes com os alunos da Universidade

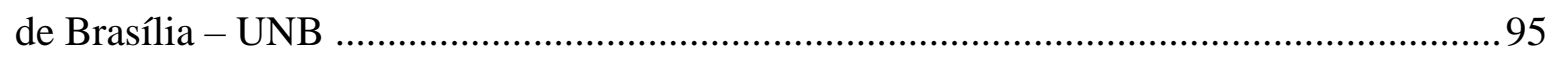

4.2. Resultados e Análise dos pré-testes.................................................. 95

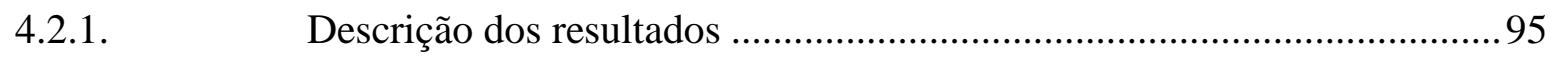

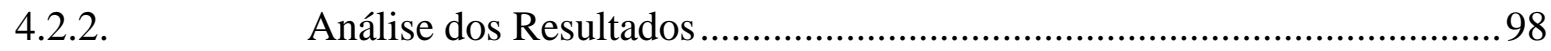

4.2.3. Descrição da persona João tendo por base os pré-testes realizados na

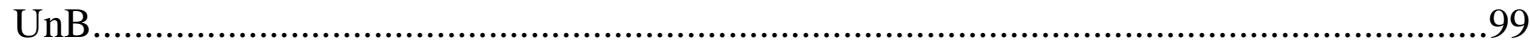

4.3. Resultados alcançados durante os pré-testes com os UDV do CEED........101

4.3.1. Observações e considerações dos alunos na entrevista, questões multiobjetivas: .102

4.3.2. Observações e considerações dos alunos na entrevista, questões

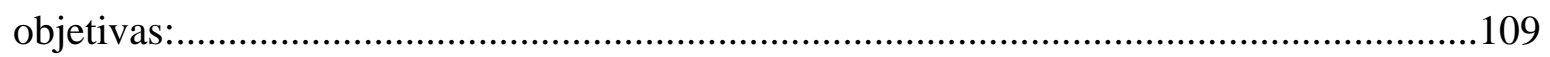

4.3.3. Principais considerações observadas pelo pesquisador: ........................111

4.3.4. Descrição da persona Mariana baseada nos pré-testes realizados no CEEDV. 111

4.4. Fase de teste do aplicativo desenvolvido para atender às personas João da

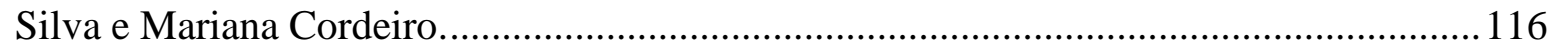

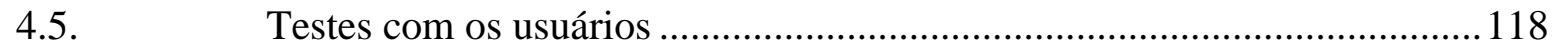

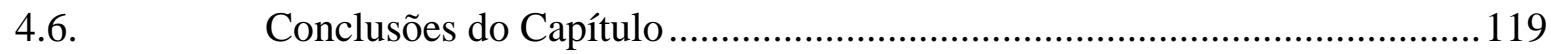

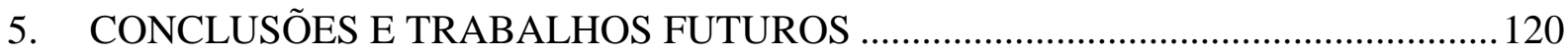


5.1. Conclusões parciais - Alunos UnB.

5.1.1. Pré-testes com os alunos da Universidade de Brasília - UNB 120

5.1.2. Conclusões para o desenvolvimento da interface acessível - Alunos UnB. 122

5.2. Conclusões parciais - usuários do Centro de Ensino Especial de Deficientes Visuais - CEEDV 122

5.2.1. Pré-testes com os usuários do CEEDV …............................................ 122

5.2.2. Conclusões para o desenvolvimento da interface acessível - usuários do CEEDV .124

5.3. Conclusões a respeitos dos testes feitos com o aplicativo e o protótipo. ... 125

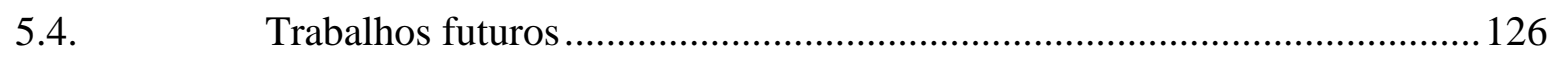

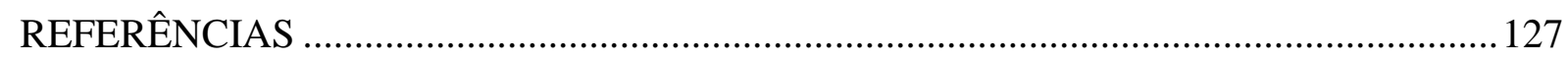

APÊNDICE A - Manual de instruções. ........................................................................ 131

APÊNDICE B - Questionário. .................................................................................. 139 


\section{INTRODUÇÃO}

\subsection{Contextualização}

Respeitar as pessoas com deficiência é criar mecanismos para que elas não sejam excluídas do convívio das outras pessoas e a acessibilidade faz parte desse respeito. Pela lei não há diferença entre os direitos das pessoas com e sem deficiência, sendo dever de todos respeitar e assegurar o acesso delas aos mesmos bens e serviços disponíveis para os demais cidadãos.

A Lei No 10.098/2000 "estabelece normas e critérios para promover a acessibilidade das pessoas portadoras de deficiência ou com mobilidade reduzida (...)" (Brasil, 10.098). De acordo com a lei, acessibilidade significa dar a essas pessoas condições para alcançarem e utilizarem, com segurança e autonomia, os espaços, mobiliários e equipamentos urbanos, as edificações, os transportes e os sistemas e meios de comunicação. Na busca de um ambiente seguro, confortável e acessível, a domótica surge como forma de economizar tempo e esforço, garantindo o bem-estar pessoal e segurança nos ambientes residenciais.

A inclusão de pessoas com deficiência nas escolas, no mercado de trabalho e na sociedade, trouxe mudanças que refletiram no perfil demográfico, urbanístico e habitacional das cidades. Por conseguinte, a automação surge como uma importante ferramenta de inclusão ao meio e no que diz respeito às soluções dos ambientes residenciais- domótica, e prediais, trazendo maior conforto, acessibilidade e segurança dos usuários em relação ao meio.

Neste contexto, uma casa acessível deve permitir que o morador possa se locomover e fazer suas atividades diárias com independência e, principalmente, com segurança. A domótica pode ser definida como um conjunto de serviços proporcionados por sistemas integrados, com o objetivo de satisfazer as necessidades básicas dos ocupantes de uma edificação (PINHEIRO, 2004); sendo que os serviços (ou parte deles) podem ser direcionados também para atender usuários com deficiências específicas.

Para que haja uma perfeita harmonia entre a automação e a acessibilidade, nos ambientes domóticos, é importante desenvolver uma ampla pesquisa sobre o usuário que virá a utilizar os recursos oferecidos por esse tipo de sistema. Os primeiros estudos relacionados e 
indexados na Library and Information Science Abstracts - LISA ${ }^{1}$ são da metade da década de 1940. Dois eventos marcaram a preocupação com estudos voltados aos usuários: (a) 1948 Conferência da Royal Society e (b) 1958 - Conferência Internacional de Informação Científica, em que foram apresentados vários trabalhos sobre estudos de usuários. Segundo Tobin (1974 apud CUNHA, 1982, p. 6), a partir da década de 1960 o termo usuário começou a ser indexado no Library Literature.

Antes das conferências supracitadas, as pesquisas relacionadas ao usuário partiam de simples descrições e, nos anos seguintes, uma postura mais analítica e avaliativa foi tomada por parte dos pesquisadores. Atualmente, o estudo do usuário é uma ferramenta para que os sistemas tecnológicos sejam sistemas com inclusão e acessibilidade, pois a partir da pesquisa e do levantamento de requisitos do usuário pode-se construir sistemas mais dedicados atendendo assim, às necessidades do público alvo.

A fim de desenvolver um sistema de automação residencial/predial que possa permitir acessibilidade aos Usuários com Deficiência Visual - UDV, sem excluir a possibilidade dos demais usuários usarem a mesma interface e o mesmo sistema, este trabalho propõe metodologias para o desenvolvimento de uma interface acessível, utilizando-se de boas práticas, normas e diretrizes, em um aplicativo para o sistema operacional Android que faça todo o controle e acionamento dos dispositivos em um ambiente residencial.

\subsection{Acessibilidade, Domótica e Interface (o tema desse trabalho).}

Nesse trabalho, os temas de acessibilidade e domótica pretendem ser ligados ao contexto do projeto de interfaces homem-computador, baseado no conceito de design universal, visando atender aos usuários com deficiências distintas. Os tópicos de design são voltados para o público em geral, porém, centrados nos UDV, em que o fator emocional é abordado a fim de se obter uma solução satisfatória a todos.

$\mathrm{Na}$ figura 1-1 têm-se as diversas relações entre as áreas de Interface Homem Computador - IHC, domótica e acessibilidade. As interseções representam os possíveis temas

\footnotetext{
${ }^{1}$ LISA - Biblioteca de Literatura e Ciência da Informação é uma base de dados bibliográfica que indexa artigos e resenhas de chave biblioteca e ciência da informação periódica publicados nos Estados Unidos e em outros lugares. Livros, capítulos de obras completas, tais como anais de congressos, teses, escola, biblioteca, e panfletos também estão indexados.
} 
de interação entre pares de áreas (interseções $a, b$ e $c$ ) e a confluência mais específica a ser abordada nesse trabalho: a intercessão $d$. Nesse sentido, a relação do tipo $a$, refere-se a tecnologias de interfaces propostas por empresas do setor de domótica para atender um público geral, envolvendo controles remotos, quadros de comandos, dispositivos baseados em touch screen, entre outros. Levando-se em consideração que os sistemas domóticos atuais envolvem sistemas microprocessados embarcados nas soluções de automação. A relação do tipo $b$ refere-se às propostas do projeto de interfaces voltadas para determinado público, por exemplo, pessoas com deficiências, porém voltadas aos contextos gerais sem envolver o tema de automação residencial. A relação do tipo $c$ refere-se aos esforços realizados para adaptar a domótica a usuários com determinadas deficiências.

Assim, as soluções podem envolver o uso de sensores, dispositivos eletromecânicos, sem fazer menção específica ao quesito de interfaces. Finalmente, a relação do tipo $d$ é uma intercessão mais específica, a qual sugere possibilidade da adaptação de tecnologias de IHC convencionais, para usuários com deficiências, e direcionadas para o uso dos recursos da domótica. Neste contexto, esse trabalho está focado na relação do tipo $d$, especificamente para atender aos UDV.

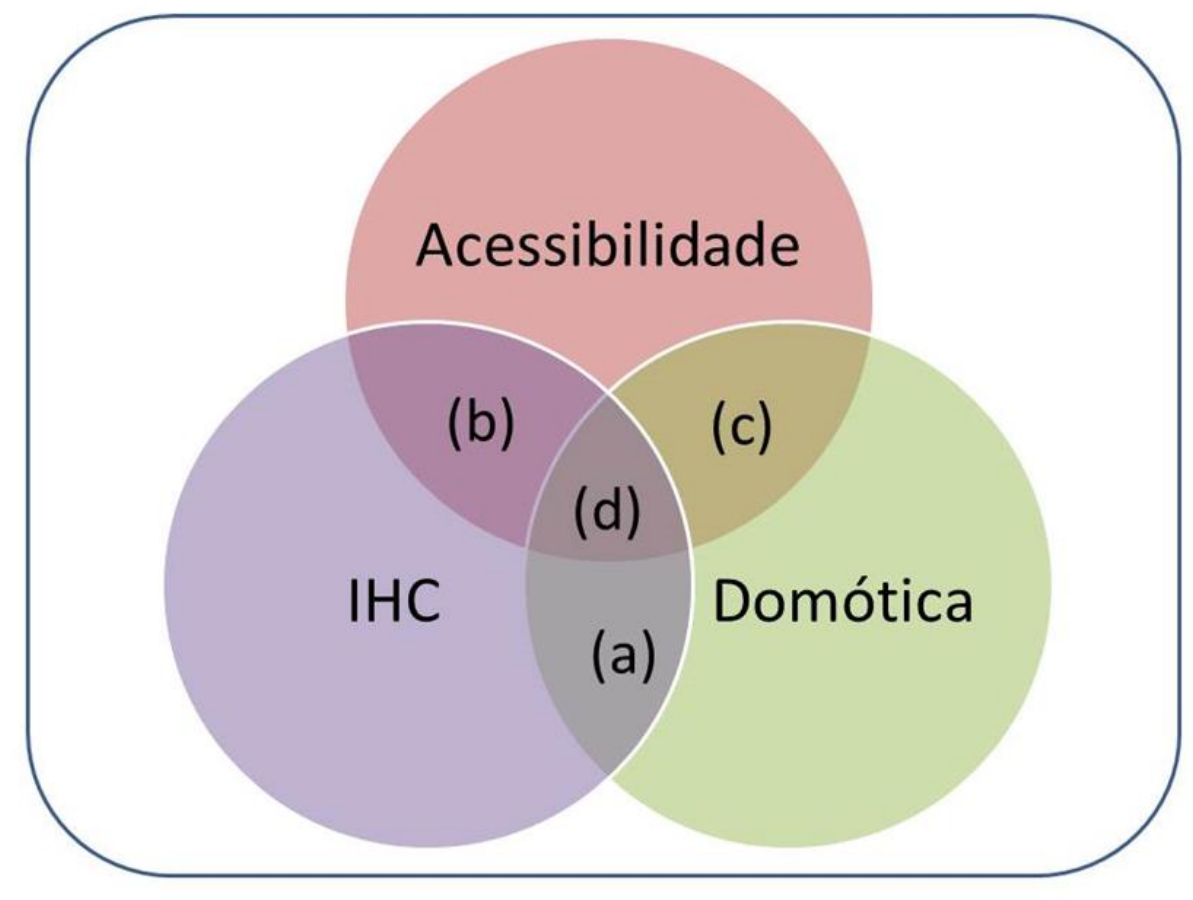

Figura 1-1- Relações entre IHC, Domótica e Acessibilidade.

Visando assegurar os direitos dos UDV, fica clara a necessidade e o potencial do uso de dispositivos tecnológicos para auxiliar na acessibilidade do meio residencial. Com o 
surgimento de novos dispositivos móveis, tais como smartphones e tablets, a automação residencial ganhou um grande aliado na vida desse tipo de usuário. Além de permitir a acessibilidade das pessoas com deficiência, a mesma gera por meio da tecnologia, uma melhor qualidade de vida a essa população.

Finalmente, podem ser observados que os conceitos envolvidos em dispositivos do tipo smartphone e tablets são altamente integrativos, envolvendo computação (tipo touchscreen, voz, teclado, etc), eletrônica digital e analógica, instrumentação (com diversos tipos de sensores embarcados) e comunicação (usando vários tipos de interfaces e protocolos), potencializando assim o projeto de novas interfaces para pessoas com diferentes características. A figura1-2 é um modelo simples de automação residencial/predial, que pode ser acessada por interfaces de um dispositivo móvel.

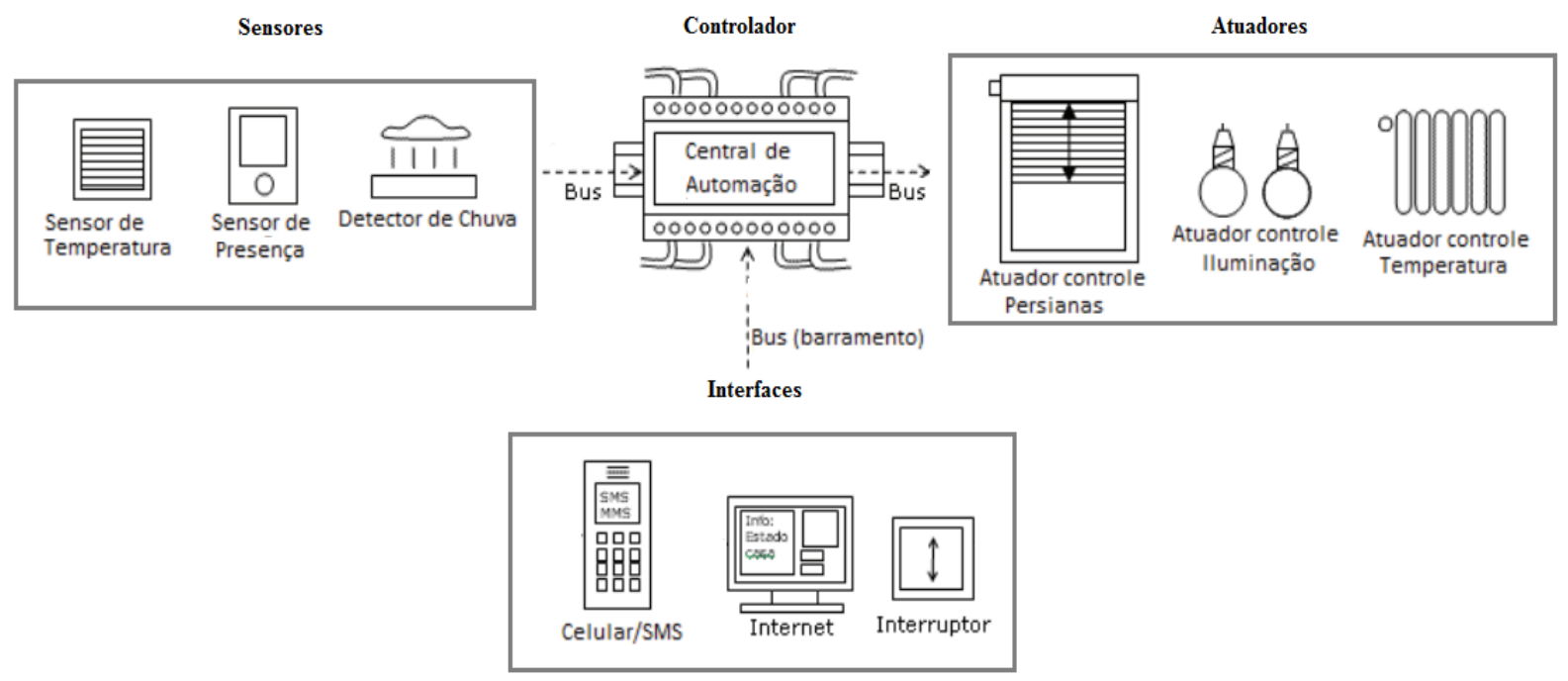

Figura 1-2 - Comunicação dos elementos básicos de uma automação residencial/predial (FONTE: adaptado de: CASADOMO, 2010)

\subsection{Objetivo geral e objetivos específicos}

Objetivo Geral:

Melhorar a acessibilidade de usuários com deficiência visual na área da domótica.

Objetivos específicos:

a) Estudar as tecnologias para o desenvolvimento de interfaces homem-máquina para usuários com deficiência visual, com usabilidade e fator emocional;

b) Identificar as necessidades do usuário com deficiência visual na área domótica; 
c) Definir um modelo de automação residencial orientado a usuários com deficiência visual;

d) Avaliar a interação no modelo proposto entre o usuário e a interface homémmáquina no contexto domótico.

\subsection{Contribuições esperadas}

Com essa pesquisa, espera-se desenvolver um método para adequar a criação das interfaces homem-máquina em ambientes de automação residencial com acessibilidade, por meio de dispositivos móveis.

O estudo se torna ainda mais relevante diante da quantidade de pessoas com deficiência no Brasil. Segundo o censo do $\mathrm{IBGE}^{2}$ do ano de 2010, no Brasil existem 45,6 milhões de deficientes, o que corresponde a 29,3\% da população brasileira. Essas pessoas podem ser beneficiadas diretamente com a inclusão de interfaces acessíveis em ambientes residenciais e prediais, possibilitando que as leis de acessibilidade e inclusão possam ser cumpridas. Além disso, espera-se que a pesquisa bibliográfica possa contribuir com novos estudos sobre o tema, iniciando os debates sobre as melhores interfaces homem-máquina para as demais deficiências.

Espera-se ainda, que os resultados encontrados nesse estudo possam contribuir para a criação de um modelo para se encontrar a melhor interface orientada a um determinado grupo de pessoas.

\subsection{Organização do trabalho}

Este estudo encontra-se dividido em cinco capítulos, além da introdução e primeiro capítulo, estruturados da seguinte forma:

O segundo capítulo trata da exposição do referencial teórico que embasará os principais estudos referentes à acessibilidade, interface homem-computador e automação residencial, temas necessários para o entendimento e consequentemente aplicação do método proposto de criação de interface acessível para um sistema domótico.

\footnotetext{
${ }^{2}$ http://www.ibge.gov.br/home/
} 
O terceiro capítulo descreve os procedimentos inerentes ao método adotado a fim de alcançar os objetivos do trabalho.

O quarto capítulo é destinado à análise dos resultados da aplicação do modelo proposto. Serão descritos e analisados os resultados alcançados durante os pré-testes com os alunos da Universidade de Brasília - UNB e durante os pré-testes com UDV do CEEDV, assim como os testes com o usuário utilizando o aplicativo que faz a interface com o sistema de automação.

O quinto capítulo apresenta as considerações finais, retomando os objetivos do estudo e ressaltando-se as conclusões da pesquisa, com sugestões para eventuais pesquisas futuras.

Por último são apresentadas as referências bibliográficas consultadas na elaboração do presente trabalho. 


\section{REVISÃO DA LITERATURA}

A tecnologia evoluiu nas últimas décadas tornando a vida das pessoas mais simples e prática, de forma geral. Para os usuários com deficiência, ela possibilitou que a restrição para realizar algumas ações seja passível de superação, ou ao menos minimizada. No caso da automação residencial, a tecnologia envolvida trás uma gama de possibilidades práticas e confortáveis, valorizando a segurança, de acordo com o interesse do usuário. Nesse sentido, o capítulo apresenta os principais conceitos para que se possam desenvolver métodos para a criação de interfaces acessíveis em automação residencial, que possam atendam a todos os usuários.

\subsection{Aspectos sobre a evolução da computação pervasiva}

O conceito de computação pervasiva implica que o computador está embutido no ambiente de forma invisível para o usuário. O computador tem a capacidade de obter informação do ambiente no qual ele está inserido e utilizá-la para dinamicamente construir modelos computacionais, ou seja, controlar, configurar e ajustar a aplicação para melhor atender as necessidades do dispositivo ou do usuário, como no caso da domótica. Nesse sentido, a computação pervasiva procura levar (ou embarcar) o computador no ambiente de forma perceptível ou não. Segundo Regina Araújo (2003, p. 50), os computadores têm a capacidade de obter informações do meio e utiliza-las a fim de construir modelos computacionais. Enquanto que a realidade virtual visa a levar o usuário para dentro do computador, mediante o uso de interfaces sofisticadas, a computação pervasiva utiliza informações do meio para controlar e configurar as aplicações de acordo com as necessidades do usuário, levando o computador a todos os ambientes possíveis.

Seguindo Weiser (1991, pp. 94-104), nas últimas décadas os usuários começaram a dar maior relevância ao uso da computação em suas rotinas, movendo a computação para fora das estações de trabalho e tornando-a cada vez mais invisível. A computação ubíqua, também chamada de ubicomp, surgiu da necessidade de se integrar mobilidade com a funcionalidade da computação pervasiva, ou seja, qualquer dispositivo computacional permite o acesso do usuário ao ambiente computacional, de todo lugar e a todo o momento, por meio de qualquer dispositivo. 
Atualmente, os estudos sobre mobilidade em sistemas distribuídos vêm sendo impulsionados pelo aumento do uso dos dispositivos móveis e pelas diversas formas de se comunicarem através de redes sem fio. Segundo M. Satyanarayanan (1996), a esse novo paradigma foi dado o nome de Computação Móvel. Para exemplificar melhor qual a relação entre a computação móvel, ubíqua e pervasiva, a figura 2-1 nos mostra que a Computação Ubíqua se beneficia dos avanços tecnológicos de ambos os ramos de pesquisa. Portanto, a UbiComp é a integração entre a mobilidade e os sistemas de presença distribuídos.

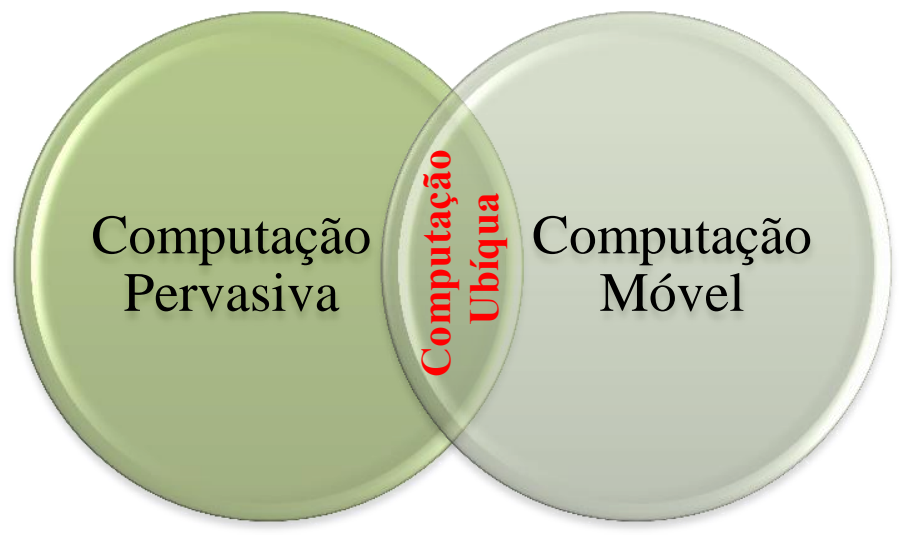

Figura 2-1 Relação entre computação pervasiva e computação ubíqua (FONTE: Adaptado de: Domingues F. L.,2008)

Segundo Bolzani (2004), a computação pervasiva auxilia, entre outras coisas, o usuário no controle domótico de modo a resultar em interfaces mais amigáveis, sistemas digitais com manutenção e administração simples. Desta forma, ajuda o usuário a cumprir as tarefas, tomar decisões, fornecendo sugestões para o gerenciamento dos sistemas. Dentro desse contexto, esse autor afirma que com a adição de inteligência em todos os equipamentos da casa é possível conseguir que todos os dispositivos inteligentes, também chamados de DIs, cooperem com a gestão da própria casa, diminuindo assim, as tarefas para o usuário. Para que esta gestão possa se adequar melhor ao usuário, faz-se necessário um estudo detalhado de suas necessidades a fim de adequar as melhores interfaces de controle aos projetos domóticos.

\subsubsection{Aspectos sobre Interface e sua aplicação em Domótica}

Ao se tratar de domótica e as possibilidades que essa pode proporcionar às pessoas com deficiência, e contextualizando seus princípios dentro das potencialidades da computação ubíqua, deve-se ter a preocupação com a interface que melhor atende às necessidades do usuário de modo a promover a acessibilidade para integrar o utilizador ao sistema. Nessa direção, Carey (1988 apud CARVALHO, 1994) define interface como um ponto de contato 
entre duas entidades. Para ela as interfaces entre o computador e os seres humanos podem abranger várias características, incluindo o meio, o diálogo e as técnicas de manipulação.

Nesse sentido, a interface é o elo entre dois sistemas, permitindo assim a comunicação entre ambos como aponta Carvalho (1994, p. 9). Em outras palavras, interface é o nome que se dá a algo que serve de ligação entre dois sistemas, independente da estrutura dos mesmos. No caso de sistemas que se caracterizam pelo processamento de informações (sistemas cibernéticos), a interface serve como elo de comunicação (um tradutor de informações), entre ambos. Assim, a expressão interface homem-computador (que denominaremos aqui de IHC: Interface Homem Computador) refere-se à interface que serve de interconexão entre dois sistemas (pessoa e computador) que trocam informações.

\subsubsection{Acessibilidade e Domótica}

Um ponto a ser abordado nesse trabalho, é o quesito de acessibilidade em um contexto diferente do apresentado na literatura especializada sobre o tema da deficiência. No contexto aqui apresentado, o foco é a acessibilidade às tecnologias de ponta, que vêm sendo inseridas no cotidiano das pessoas, envolvendo o potencial de sistemas embarcados cada vez mais sofisticados, os quais fazem uso de processadores cada vez mais eficientes. Isso tem permitido o projeto de interfaces mais sofisticadas. Adicionalmente, neste trabalho é abordado o tema de acessibilidade de usuários com diferentes tipos de deficiência à domótica, do ponto de vista de facilitar o uso de tecnologias de ponta, envolvendo sensores e atuadores modernos; sempre visando a atender as necessidades básicas tais como conforto, segurança e comunicação.

Em se tratando de domótica e visando atender ao foco desse trabalho, o tema de interfaces tem uma importância nítida, a qual deve tratar de facilitar o acesso de pessoas com deficiências às tecnologias cada vez mais populares. De modo claro, pretende-se fazer uma reflexão sobre uma domótica que vise também a atender aos usuários com deficiência, em suas particularidades. Desta forma, a mesma vem sendo influenciada pelo desenvolvimento da computação ubíqua, que traz transparência no quesito de processamento para os usuários, tendo em conta a possibilidade de se ter múltiplos sistemas de processamento, os quais podem estar espalhados em todo o ambiente, e mesmo fora dele, trabalhando de maneira transparente para os usuários. 
Dessa maneira, informações provenientes de sensores, tais como RFIDs (RadioFrequency Identification), cartões inteligentes (smart-cards), sensores de luminosidade, de temperatura, de humidade, entre outros, podem ser processadas de maneira rápida, e transmitidas por meio de redes específicas.

Adicionalmente, pode ainda ser observado que uma tecnologia de comunicação tal como os dispositivos móveis, envolvendo celulares e tablets, representa um aglutinador de tecnologias de ponta com enfoque no poder computacional. Interfaces baseadas em touch screen, reconhecedores e sintetizadores de voz, sensores de temperatura, GPS, assim como unidades inerciais (IMUs- Inertial Measurement Units). Neste caso, o conjunto tecnológico fornece uma capacidade imensa de informações processadas para os usuários, potencializada pela acessibilidade à web, a qual permite de maneira concreta, e quase transparente, a comunicação dos usuários com interlocutores que podem estar em qualquer lugar do planeta. Por esses motivos, dispositivos móveis com aplicações em domótica estão sendo cada vez mais utilizados.

\subsection{Conceitos básicos sobre projeto de Interfaces, Acessibilidade e Domótica.}

\subsubsection{Acessibilidade}

De acordo com a Lei n. ${ }^{\circ} 13.146$ de 6 de julho de 2015 é dever do Estado assegurar que todas as pessoas, com ou sem deficiência, tenham a possibilidade de viver de modo independente. Para tanto é necessário que sejam geradas medidas que visam seja acessibilidade quanto autonomia para qualquer grau de deficiência. Por exemplo, na Lei n. ${ }^{\circ}$ 10.098 de 19 de Dezembro de 2000 se encontram definições importantes para o estudo da acessibilidade, dentre elas, a de "portadores de deficiência" ${ }^{3 "}$ ou com mobilidade reduzida, explicitados a seguir:

(...) Acessibilidade: a possibilidade e condição de alcance para utilização, com segurança e autonomia, dos espaços, mobiliários e equipamentos urbanos, das edificações, dos transportes e dos sistemas e meios de comunicação, por pessoa portadora de deficiência ou com mobilidade reduzida.

Pessoa portadora de deficiência ou com mobilidade reduzida: a que temporária ou permanentemente tem limitada sua capacidade de relacionar-se com o meio e de utilizá-lo. (...). (BRASIL, 10.098)

3 O termo "portadores de deficiência" é utilizado conforme documento de referência. Neste trabalho, usamos a terminologia "pessoa com deficiência", de acordo com a Convenção da ONU sobre direitos das pessoas com deficiência. 
Nessa perspectiva, a domótica trouxe maior facilidade para tornar ambientes residenciais acessíveis aos usuários com quaisquer limitantes. Portanto, tornar ambientes automatizados possibilita melhora na qualidade de vida desses usuários. Nesse contexto, a acessibilidade é um requisito contemporâneo à qualidade no uso de sistemas interativos (ABNT, 2005a; ABNT, 2005b; BARANAUSKAS e DE SOUZA, 2006). Um sistema que não oferece a mínima condição de acesso e de interação para um determinado usuário em uma situação específica de uso, nem mesmo pode ser avaliado adequadamente quanto a sua eficácia, eficiência e satisfação para esse utilizador (DIAS, 2003).

\subsubsection{Pessoas com deficiência}

Uma pessoa pode apresentar uma deficiência congênita ou adquirida em decorrência de um evento aleatório ao longo da vida. Essas deficiências variam desde alguma dificuldade para andar, para ouvir e para enxergar, até as lesões incapacitantes. O decreto $\mathrm{n}^{\circ} .3 .298$ de 20 de dezembro de 1999, que regulamenta a Lei $\mathrm{n}^{\circ} .7 .853$ de 24 de outubro de 1989 dispõe sobre a Política Nacional para a Integração das pessoas deficientes, em seu capítulo primeiro, Art. 3, o termo deficiência como toda perda ou anormalidade de uma estrutura ou função psicológica, fisiológica ou anatômica que gere incapacidade para o desempenho de atividade dentro do padrão considerado normal para o ser humano. Pelo decreto nª 5.296 de 2004 são definidos os vários tipos de deficiência estabelecidos por Lei, descritos a seguir:

- Deficiência física - alteração completa ou parcial de um ou mais segmentos do corpo humano, acarretando o comprometimento da função física;

- Deficiência auditiva - perda bilateral, parcial ou total, de quarenta e um decibéis (dB) ou mais, aferida por audiograma nas frequências de $500 \mathrm{HZ}, 1.000 \mathrm{HZ}, 2.000 \mathrm{~Hz}$ e $3.000 \mathrm{~Hz}$.

- Deficiência visual - cegueira, na qual a acuidade visual é igual ou menor que 0,05 no melhor olho, com a melhor correção óptica; a baixa visão, que significa acuidade visual entre 0,3 e 0,05 no melhor olho, com a melhor correção óptica; os casos nos quais a somatória da medida do campo visual em ambos os olhos for igual ou menor que 60; ou a ocorrência simultânea de quaisquer das condições.

- Deficiência mental - funcionamento intelectual significativamente inferior à média, com manifestação antes dos dezoito anos e limitações associadas a duas ou mais áreas de habilidades adaptativas, tais como:

a) Comunicação;

b) Habilidades sociais; 
c) Saúde e segurança;

d) Habilidades acadêmicas;

e) Lazer; e

f) Trabalho;

- Deficiências múltiplas - associação de duas ou mais deficiências.

Destaca-se, ainda, que a concepção de pessoa com deficiência adotada pelos autores deste trabalho tem como base o Decreto $\mathrm{n}^{\mathrm{o}}$. 6.949 de 2009, que promulga a Convenção Internacional sobre os Direitos das Pessoas com Deficiência, pautando movimentos mundiais e representando um grande marco histórico no movimento pela defesa de direitos humanos e de liberdades fundamentais de pessoas com deficiência. Em geral, a convenção da Organização das Nações Unidas - ONU reconhece que a:

"deficiência é um conceito em evolução que resulta da interação entre pessoas com deficiência e as barreiras latitudinais e ambientais que impedem sua plena e efetiva participação na sociedade em igualdade de oportunidades com as demais pessoas." (BRASIL, 2009).

Para satisfazer ao usuário, de acordo com suas necessidades, perspectivas e deficiências, faz-se necessário um estudo específico para cada caso. Com esse estudo, seria possível desenvolver métodos e interfaces que sejam acessíveis às suas diversidades.

No contexto de inserção social, para pessoas com deficiência, pode-se citar o que está estabelecido por lei na Constituição Federal, nos princípios fundamentais em seu artigo primeiro para todos os cidadãos. Sabe-se da importância da informação para o desenvolvimento do ser humano em toda a sua dimensão; principalmente, no caso das PDV, devido às dificuldades enfrentadas no acesso e aquisição de informações. Segundo a fundação Dorina Nowill para cegos podem-se classificar as PDV em dois principais grupos:

- Cegueira - há perda total da visão ou pouquíssima capacidade de enxergar, o que leva a pessoa a necessitar do Sistema Braille como meio de leitura e escrita;

- Baixa visão ou visão subnormal - caracteriza-se pelo comprometimento do funcionamento visual, mesmo após tratamento ou correção. As pessoas com baixa visão podem ler textos impressos e ampliados ou com uso de recursos óticos especiais. 
Assim, o decreto $\mathrm{n}^{\mathrm{o}}$. 6.949 reconhece textualmente "a importância da acessibilidade aos meios físico, social, econômico e cultural, à saúde, à educação e à informação e comunicação, para possibilitar às pessoas com deficiência o pleno gozo de todos os direitos humanos e liberdades fundamentais (BRASIL Nº 6.949, 2009)". A fim de contribuir para que esse decreto seja cumprido, este trabalho tem como foco a acessibilidade dos UDV em ambientes domóticos.

Portanto, todos os usuários com deficiência possuem os mesmos direitos, porém, para fim de pesquisa, foi escolhida apenas uma deficiência (a deficiência visual). Entretanto, com base nos métodos desenvolvidos nesta pesquisa, os resultados da mesma poderão ser estendidos às demais deficiências no futuro.

Os profissionais que exercem suas funções diretamente com PDV compreendem que o uso de computador e o acesso à internet podem fazer uma grande diferença na vida das PDV, como melhoria educacional, oportunidade de emprego, aumento das redes sociais (por e-mail e grupos on-line) e da independência (com acesso pessoal à informação). Neste sentido, a literatura aborda as melhores técnicas, práticas e diretrizes para facilitar o acesso à informação de PDV sem comprometer o design e o layout para os usuários videntes (GERBER 2003 apud CASELLI 2007, p. 23).

Dados de Nascimento (2013) ressaltam a importância e a necessidade de incentivos políticos em ambientes acadêmicos para a realização de pesquisas sobre produtos para uma pessoa com deficiência visual. Fica claro, que os produtos projetados no Brasil com poucos recursos não oferecem ao público com deficiência grande potencial e apoio. Nesse sentido, foi possível comparar os produtos existentes para os cidadãos com deficiência visual no Brasil e nos Estados Unidos. Para essa análise, foram utilizados os dados disponibilizados pela American Foudation for Blind (AFB) organização sem fins lucrativos, que oferece uma listagem de produtos recomendados para pessoas com deficiência.

Segundo os dados obtidos pela Pesquisa Nacional de Tecnologia Assistiva do Instituto de Tecnologia Social (ITS, 2007), grande parte das pesquisas realizadas com relação a produtos para as pessoas com deficiência não alcança a indústria e comercialização, pois não atravessa o limiar acadêmico. Por sua vez, as abordagens de PDP (Processo de Desenvolvimento de Produto) não possuem, em sua maioria, mecanismos específicos para tratar aspectos relativos ao desenvolvimento de produtos para essa população. Com base no 
estudo das necessidades dos usuários e suas respectivas deficiências é fundamental a caracterização de demandas específicas de cada grupo de deficiência (física, visual, auditiva, entre outras) possibilitando assim desenvolver métodos e interfaces que sejam acessíveis e funcionais a cada grupo.

Cunha (1982), já defendia em sua publicação a importância de diálogo, de questionários e de entrevistas para melhor atender as necessidades do usuário. A Tabela 2-1 mostra algumas das formas que se podem extrair os dados do usuário, segundo Cunha.

Tabela 2-1 Métodos para o estudo do usuário (Adaptado de CUNHA, 1982).

\begin{tabular}{|c|c|c|c|c|}
\hline Perguntas & Observação & $\begin{array}{c}\text { Análise } \\
\text { Documentária }\end{array}$ & Vantagens & Desvantagens \\
\hline \multirow[b]{3}{*}{ Questionário } & \multirow[b]{3}{*}{$\begin{array}{l}\text { Observação } \\
\text { participante }\end{array}$} & \multirow[b]{3}{*}{ Diários } & \multirow[b]{3}{*}{ Rápido e barato } & Resolver ambiguidades \\
\hline & & & & Índice de resposta baixo \\
\hline & & & & $\begin{array}{l}\text { Prazo estipulado pode-se } \\
\text { perder questionários que } \\
\text { foram respondidos fora do } \\
\text { prazo. }\end{array}$ \\
\hline \multirow{2}{*}{ Entrevista } & \multirow{2}{*}{$\begin{array}{l}\text { Observação } \\
\text { participante }\end{array}$} & \multirow{2}{*}{$\begin{array}{l}\text { Análise de } \\
\text { conteúdo }\end{array}$} & $\begin{array}{l}\text { Contrato direto com o } \\
\text { entrevistador. }\end{array}$ & Pode ter distorções \\
\hline & & & $\begin{array}{l}\text { O entrevistador pode solicitar } \\
\text { detalhes das respostas. }\end{array}$ & $\begin{array}{l}\text { Custa caro devido a } \\
\text { necessidade de treinamento } \\
\text { do entrevistador }\end{array}$ \\
\hline \multirow[t]{2}{*}{$\begin{array}{l}\text { Técnica } \\
\text { de Delfos }\end{array}$} & & $\begin{array}{l}\text { Análise de } \\
\text { citações }\end{array}$ & $\begin{array}{l}\text { Como indicador de futuro, } \\
\text { permite fazer as correlações } \\
\text { ou mesmo se preparar para } \\
\text { possíveis eventos. }\end{array}$ & $\begin{array}{l}\text { Exigi conhecimento de } \\
\text { estatística }\end{array}$ \\
\hline & & $\begin{array}{l}\text { Documentos de } \\
\text { biblioteca }\end{array}$ & $\begin{array}{l}\text { É um enfoque sistemático } \\
\text { que solicita opiniões de } \\
\text { especialistas. }\end{array}$ & $\begin{array}{l}\text { É possível que os } \\
\text { resultados não sejam } \\
\text { verdadeiros no futuro. }\end{array}$ \\
\hline
\end{tabular}

\subsubsection{Conceitos básicos sobre Automação Residencial (Domótica)}

Segundo Lacomber (2004), automação é a aplicação de técnicas computadorizadas ou mecânicas para diminuir o esforço reduzindo os custos e aumentando a velocidade da produção. Em um ambiente residencial a automação denomina-se domótica, termo resultado da junção de domus que significa casa, com a palavra robótica, dando o sentido de controle. Para que a tecnologia seja incorporada de forma a se tornar praticamente transparente para os usuários (parecendo indistinguível), Weiser (1991) introduziu o princípio de computação ubíqua como ideia de inserir a computação pervasiva nos ambientes residenciais. 
Nesse caso, dois parâmetros que mais interferem nos ambientes domóticos, principalmente na computação ubíqua são: (a) a questão da segurança dos usuários e (b) o problema de segurança de seus respectivos. Adicionalmente, deve-se estar atento aos princípios de confiabilidade, disponibilidade e integridade dos dados, independentemente se o usuário apresenta deficiência ou não. Para satisfazer as necessidades básicas de segurança, comunicação, gestão energética e conforto de uma habitação Muratori e Bó (2011, pp. 70-76) definem que um sistema de automação residencial consiste no conjunto de serviços que podem ser proporcionados por um sistema tecnológico integrado ao meio. Para que essa integração seja eficiente, atendendo bem as necessidades específicas da automação domótica, utilizam-se sistemas integrados de sensores e atuadores.

Sensores são equipamentos que agem no ambiente externo ao usuário, captando informações tais como temperatura, umidade, posição geográfica, entre outros. Tornam-se essenciais na indústria, e consequentemente, no cotidiano dos usuários. Um sensor se comporta como um transdutor, quando inclui um elemento conversor da variável, ou seja, transforma uma grandeza física qualquer em outra, (por exemplo, em elétrica). Um exemplo clássico é o termopar, sendo um sensor de temperatura cuja saída é uma tensão elétrica proporcional à temperatura que está monitorando. De maneira geral, os sensores e transdutores são grandes aliados da domótica, trazendo facilidade e consequente acessibilidade aos usuários.

Atuadores são definidos como elementos capazes de recebem um sinal proveniente de um controlador e em resposta a um comando manual ou automático, modificar grandezas físicas controladas. Exemplos de alguns atuadores:

1. Válvulas (pneumáticas, hidráulicas);

2. Relés;

3. Cilindros (pneumáticos, hidráulicos);

4. Motores;

5. Solenoides entre outros.

Os atuadores são dispositivos eletromecânicos, que recebem os comandos do sistema de automação e ativam os equipamentos automatizados. São os módulos de acionamento ligados entre a rede elétrica e os equipamentos que se favorecem com a acessibilidade dos ambientes domóticos, por meio do design centrado no usuário e interfaces dedicadas com design emocional adequado, é preciso entender as características destes usuários (ALMEIDA, 
2009). No contexto deste trabalho o tema será focado no usuário com deficiência visual, pelos seguintes motivos: (a) segundo o IBGE (2010) no Brasil existe mais de 35 milhões de PDV; (b) entre estas pessoas, mais de 6,5 milhões disseram ter a dificuldade de forma severa e seis milhões afirmaram que tinham dificuldade de enxergar; (c) mais de 506 mil informaram serem cegas.

\subsubsection{Aspectos de Segurança: o método de Árvore de Falhas}

O método da árvore de falhas foi desenvolvido em 1961, pela empresa americana Bell Telephone e trata-se de uma metodologia que visa identificar e encadear, de forma lógica os diversos eventos que podem acontecer separadamente ou em conjunto, que conduzirão a um determinado modo de falha. Ela é representada em forma de diagrama, utilizando operadores lógicos simples, tais como and e or para encadear essas relações. Segundo Baptista (2008) é o método de maior aplicação no âmbito de análises de riscos das mais diversas áreas, designadamente, nas indústrias aeronáutica, nuclear e química.

Ao partir de um possível evento indesejável é possível, por meio da FTA, conhecer as suas causas particulares. No contexto da árvore de falhas, esse evento indesejável é conhecido como evento de topo (ET) a partir do qual é desenvolvida a árvore na direção vertical. Caldeira (2005) aponta que o ET deve ser definido com base no estado que constitui a ruptura de um sistema em condições externas e nos termos e procedimentos de operação. O sistema aqui sugerido é um sistema domótico, que visa à acessibilidade das PDV, desse modo é imprescindível que esse esteja sempre disponível e tenha confiabilidade elevada.

Assim, fica clara a importância da técnica da FTA de forma a se ter confiabilidade e disponibilidade no sistema, visando assim reduzir ao máximo as falhas e o tempo de indisponibilidade do mesmo. Tendo por base que o sistema funciona primeiramente utilizando energia, fica evidente que, assim como na década de 80, o gasto energético continua a ser muito importante tornando a ser até, nesse caso, o evento topo (ET) da árvore de falhas. É importante salientar que, quando se fala de energia utilizamos o modo amplo da palavra e não somente a energia elétrica, mas também a energia mecânica, hidráulica, térmica entre outras.

Com a energia assegurada, o sistema tem a possibilidade de funcionar de acordo com os parâmetros configurados pelo usuário. No caso particular, a energia elétrica é o evento topo do sistema de automação seguindo pela internet e a interface amigável do dispositivo móvel. 
Para que a comunicação seja eficiente o usuário deve estar ciente dos acontecimentos entre a central e o dispositivo móvel, inclusive das falhas.

Uma das características que a comunicação possibilita é a interatividade. Por meio dessa é permitida a programação desde que os sistemas envolvidos obedeçam a certa padronização.

\subsubsection{Aspectos de comunicação na domótica}

Em geral, o sistema domótico é composto de uma rede de comunicação que permite a interconexão de uma série de dispositivos, equipamentos e outros sistemas, com o objetivo de obter informações sobre o ambiente residencial e o meio em que ele se insere efetuando determinadas ações a fim de supervisioná-lo ou gerenciá-lo. Conforme o modelo OSI é a camada física a responsável pela transmissão bruta dos dados por meio de um canal de comunicação. Para isso, alguns parâmetros são definidos como, por exemplo, a modulação do sinal e a frequência da banda utilizada.

Dispositivos como detectores, sensores, captadores e atuadores trocam informações entre eles ou com unidades centrais inteligentes, no caso a central de automação, sendo capazes de processar os dados recebidos e enviar sinais para efetuar acionamentos ou ajustes, a determinados equipamentos e/ou gerar sinalizações e/ou avisos, podendo ainda, em alguns casos, receber respostas de confirmação da operação.

Esse tipo de mecanismo de resposta torna o sistema de automação acessível. Utilizando-se de e-mail de confirmação, mensagens de celular, bips sonoros, vibracall entre outros há possibilidade que o sistema e o usuário com deficiente visual se comuniquem de forma eficiente. $\mathrm{O}$ usuário pode assim tomar ciência do que está acontecendo no sistema e se sua requisição foi atendida garantindo assim a acessibilidade e o projeto de interfaces baseado no design universal, que atenda usuários com características distintas. Os tópicos de design são voltados para o público em geral, porém centrados nos UDV, onde o tema do design emocional é abordado a fim de se obter uma solução satisfatória a todos em um ambiente domótica.

\subsubsection{Protocolos utilizados na domótica}

- Protocolo CAN - (Controller Area Network) 
Com o passar do tempo, um maior número de periféricos tiveram a possibilidade de serem automatizados facilitando a automação dos ambientes e tornando mais acessíveis e confortáveis aos usuários. Com o uso de mais periféricos, surge à necessidade de centralizar esta automação em um único microprocessador a fim de baratear e simplificar a manutenção, além de diminuir fios e melhorar a estética dos ambientes. A possibilidade de inserir novos sensores e atuadores de forma fácil e segura, diminuindo ruídos, também foi levada em conta no uso dessa escolha. Para que dois ou mais dispositivos se comuniquem, é preciso que eles falem o mesmo protocolo. Nesse contexto, o protocolo define o formato e a ordem das mensagens trocadas e também das ações tomadas na transmissão e/ou recebimento de uma mensagem (KUROSE et al., 2000).

Na década de 1980, foi desenvolvido por Robert Bosch o protocolo CAN (Controller Area Network) ou Rede de Área de Controle. Categorizada como uma rede fieldbus, síncrona e composta por microcomputadores/microcontoladores destinada principalmente para a indústria automotiva, porém, em pouco tempo esse padrão foi levado para outras áreas de aplicação como caminhões, ônibus, barcos, satélites, máquinas agrícolas, construção civil e militar, além de outros padrões nas áreas de automação industrial, robótica e instrumentação médica (SOUSA, 2002). Esse protocolo possuía em sua especificação elevada taxa de transmissão, grande imunidade a interferências elétricas e capacidade de detectar erros. Ao longo dos anos, o protocolo CAN tornou-se grande aliado em produtos envolvendo microcontoladores por ter uma forma simples, barata e robusta, nomeadamente ao ruído eletromagnético. Hoje é utilizado em diferentes segmentos como: automação predial e residencial, equipamentos hospitalares e simuladores de voo. Esse protocolo está situado na camada física e de enlace do modelo OSI - Open Systems Interconnection (BOLZANI, 2004). Guimarães e Saraiva (2002), apontam como principais características da arquitetura CAN:

- Multi-mestre: todos os elementos da rede podem tornar-se mestre ou escravos do barramento;

- Multicast: quando um elemento da rede envia uma mensagem, todos os outros recebem;

- CSMA/CD com NDA (Non-Destructive-Arbitration): antes de enviarem uma mensagem, os elementos da rede verificam se existe alguma mensagem sendo enviada no barramento. Caso dois elementos enviem a mensagem simultaneamente, a de menor prioridade é interrompida para que seja transmitida a de maior prioridade;

- NRZ (Non Return to Zero): cada bit transmitido representa efetivamente um dado; 
- A taxa de transmissão de dados pode chegar a um (1) Mbps, dependendo do comprimento do barramento;

- Robustez em detecção de falhas;

- Alta imunidade à interferência eletromagnética.

O CAN é um padrão baseado no paradigma de orientação a mensagem (SOUSA, 2002), por essa razão os periféricos na rede não possuem endereço, mas são as mensagens que possuem seus próprios identificadores específicos. Cada protocolo, baseado no CAN, define o endereço das mensagens de uma maneira diferente, sendo assim, existem protocolos que definem um endereço para cada tipo de dispositivo ou grupo deles dentro de uma rede.

A mensagem de autenticação difere-se das demais nos campos endereço e conteúdo. Em seu lugar, são enviados os campos usuário e senha contendo o nome do usuário no sistema e sua senha, respectivamente (EUZÉBIO, 2011). Para toda requisição enviada do cliente, o servidor envia uma resposta, podendo ser uma mensagem de sucesso ou de erro, quanto à operação realizada (EUZÉBIO, 2011).

Considerado um sistema de barramento em série, o CAN é apropriado para ligar sensores e atuadores em um ambiente domótico, por meio do qual a informação transmitida possui tamanho curto possuindo no máximo de oito (8) bytes de informação útil, sendo, no entanto, possível transmitir blocos maiores de dados recorrendo à segmentação. $\mathrm{O}$ número de elementos num sistema CAN está teoricamente, limitado pelo número possível de identificadores diferentes. Esse número limite é significativamente reduzido por questões físicas do hardware.

\section{- Frame CAN}

Os dispositivos podem enviar os dados por meio da rede em pacotes chamados frame. O frame CAN pode ser de dois tipos: standard ou extended. Na versão standard (CAN 20A), o campo do frame que identifica o tipo da mensagem a ser transmitida é formado de 11 bits, enquanto que, na versão extended (CAN 20B), esse parâmetro é formado por 29 bits (11 bits standard mais 18 bits extended), possibilitando até 5,3 milhões de tipos de mensagens distintas. Em ambas as versões, podem ser transmitidas até oito bytes de dados por frame (GUIMARÃES; SARAIVA, 2002). 
- Hardware CAN

Em um projeto eletrônico de um dispositivo compatível com o protocolo CAN, devese considerar a utilização de um controlador e um transceptor CAN. Alguns microcontroladores já apresentam, em sua arquitetura interna, um módulo de hardware controlador CAN, necessitando apenas do transceptor (GUIMARÃES; SARAIVA 2002).

Apesar de o CAN ter se tornado um dos protocolos de comunicações com maior aceitação, para esse projeto foram comparados alguns dos principais protocolos de comunicação utilizados em automação residencial a fim de implantar o que mais satisfaça os requisitos da aplicação.

\section{- Protocolo X-10 PLC}

O sistema X-10 PLC (Power Line Carrier), desenvolvido em 1978, pela empresa escocesa Pico Eletronics Ltd, em Glenrother, é o protocolo mais antigo e popular de automação residencial com o objetivo de transmitir dados por meio da linha elétrica, em uma única via. Como a rede elétrica pode ocasionar alguns comportamentos imprevisíveis dos componentes, seja por problemas de ruído, seja por falta de energia ou descargas eletromagnéticas, não é recomendado para aplicações que exijam maior nível de segurança (BOLZANI, 2004).

O protocolo em questão é aberto, isto é: qualquer fabricante pode incluir um módulo de comunicação X-10 nos seus produtos e oferecê-los ao público, tornando a tecnologia mais acessível para uma instalação domótica não muito complexa. Os módulos transmissores do X10 são adaptadores, que conectados a interruptores enviam sinais aos módulos receptores para fazer o controle de simples equipamentos.

A atribuição de endereços aos vários dispositivos X-10 é feita manualmente nos próprios dispositivos atuando sobre dois seletores rotativos. Em um deles é escolhido o código da casa, e no outro é escolhido o código do dispositivo. O esquema de endereçamento permite armazenar 256 pontos diferentes. A transmissão é em broadcast e todo o comando é repetido duas vezes. Os dispositivos X-10 limitam-se ao controle de liga e desliga e a intensidade luminosa. 


\section{- Protocolo INTELLON CEBUs}

Produzido pela empresa Intellon o protocolo CEBus (Consumer Electronics Bus), também conhecido por Associação das Indústrias de Eletrônicas - EIA-600, é um protocolo aberto que segue o modelo OSI contemplando os níveis físico, lógico, rede e de aplicação. As suas raízes datam de 1984, tendo sofrido uma constante evolução até ter sido objeto de normalização (ANSI/EIA-600) em 1995.

Esse modelo opera em redes ponto a ponto permitindo o acesso em qualquer nó a qualquer instante, dispensando o uso de um sistema centralizado. Uma de suas vantagens é que qualquer dispositivo é capaz de se comunicar com outro pela rede elétrica sem a necessidade de um novo cabeamento.

Desenvolvido para a comunicação de produtos eletroeletrônicos em redes elétricas residências e comerciais, utiliza a tecnologia Spread Spectrum Carrier (SSC), baseada na transmissão de símbolos SSC (chirps) com frequência variável (spread spectrum) consistindo em um protocolo complexo e muito poderoso.

\section{- Protocolo ECHELON LonWorks}

Em 1992, a Echelon Corporation ${ }^{4}$ apresentou a tecnologia LonWorks, um sistema híbrido, robusto e flexível que se comunica por um protocolo ponto a ponto que dispõe de serviços como autenticação, prioridade, detecção de erros, entre outros. Normatizada em 1995 pela EIA 709.1 essa tecnologia possibilita a criação de sistemas abertos e distribuídos para soluções em automação industrial, residencial, sistemas de transporte e redes de controle gerais.

Devido ao seu custo elevado em comparação as demais tecnologias com prestações iguais, os dispositivos LonWorks não têm tido grandes implementações mantendo seu êxito em aplicações profissionais nas quais importa muito mais a confiabilidade e a robustez que o preço. Sua utilização se deve quando desde a origem oferece uma solução com arquitetura descentralizada, extremo a extremo, que permite distribuir a inteligência entre os sensores e os atuadores instalados e que cobre desde o nível físico até o nível de aplicação a maioria dos projetos de redes de controle. (ECHELON, 2010).

\footnotetext{
4 Para maiores informações: 〈http://www.echelon.com/support/documentation>
} 
- Protocolo ZIGBEE 802.15.4

O protocolo ZigBee foi idealizado pela ZigBee Alliance, que visou criar um produto de baixo custo, para aplicações prediais, residenciais e industriais além de oferece solução em rede sem fio, com baixo consumo de potência. Esse protocolo está definido nas camadas mais baixas (Camada de Rede, de Enlace e Física), as camadas mais altas são desenvolvidas dependendo da aplicação.

Segundo Bolzano (2004), o desenvolvimento dessa tecnologia se deu por meio do esforço de diversas companhias entre elas, a Honeywell, Invensys, Mitsubishi, Motorola e Samsung formando a Aliança ZigBee. Com objetivo de buscar facilidades, por meio de soluções sem fio para as aplicações dos produtos usuais e para tal, forneceram uma plataforma de atendimento às necessidades de controle e monitoração remota, de forma simples, confiável, de baixo custo e reduzido consumo de energia.

A tecnologia ZigBee suporta baixas taxas de dados e atende ao monitoramento e controle remotos com baixo consumo de potência e capacidade de alcance de 10 a 75 metros podendo conectar até 255 dispositivos para monitoramento. A topologia da rede é baseada em nós e podem ser configuradas tanto peer-to-peer como em estrela. Por definição, existem dois tipos de nós: os FFD - Full-Function Devices ou dispositivos de funcionamento completo, e os RFD - Reduced Function Devices ou dispositivos de funcionamento reduzido.

- Protocolo Z-WAVE

A tecnologia $Z$-Wave foi desenvolvida e é autorizada por uma companhia conhecida como Zensys dinamarquesa. É um protocolo de comunicação completamente sem fios, que se utiliza de radiofrequência para estabelecer sua comunicação, sem mão dupla recebe e envia em uma frequência de $908 \mathrm{Mhz}$, que usa uma largura da banda estreita para enviar comandos de controle.

Segundo a Sylvania Home Automation (2005) ${ }^{5}$, apoia-se no modelo estrutural de rede em malha, que permite que dois nós utilizem outros nós para efetivar sua comunicação, podendo ter até 232 dispositivos colocados em uma distância máxima de 30m. Outro dado importante é que a largura da banda não é suficiente para transmissão de áudio ou vídeo.

\footnotetext{
${ }^{5}$ Para maiores informações: <http://www.unical-usa.com>
} 
Segundo a documentação oficial da Zen-sys Technology ${ }^{6}$, a tecnologia Z-Wave transforma qualquer dispositivo isolado em um dispositivo de rede inteligente, que pode ser controlado e monitorado por meio de um sistema de comunicação sem fio consumindo pouca energia, em razão de a velocidade na transmissão dos dados ser baixa. Cada chip possui seu próprio endereço na rede, evitando assim, conflitos de endereços (DRITSAS, 2010). Controles remotos ou painéis sensíveis ao toque podem ser utilizados como interface de configuração para o usuário (Z-WAVE, 2010).

\section{- Protocolo ETHERNET / IEEE 802.3}

Ethernet é uma tecnologia de comunicação em rede local com meio de transmissão compartilhado e padronizado no modo IEEE 802.3 (TANENBAUM, 2003). Utiliza-se do protocolo CSMA/CD - Carrier Sense Multiple Access with Collision Detect, que significa que se trata de um protocolo de acesso múltiplo com vigilância de portador carrier sense e detecção de colisão.

As redes Ethernet para coordenarem o acesso ao meio de transmissão, ligadas a uma mesma linha de transmissão, têm os endereçamentos feitos com base em uma sequência de seis bytes (48 bits) habitualmente conhecida por endereço físico, endereço MAC ou endereço "ethernet". Por estar em constante evolução, essa tecnologia pode chegar a uma taxa de transmissão de 10 Gbps. Nesse protocolo não existe prioridade de transmissão entre as máquinas. Algumas empresas desenvolvem adaptadoras pensando na interoperabilidade com o padrão Ethernet, pois isso facilita a aceitação desses produtos no mercado (BOLZANI, 2004).

- $\quad$ IEEE $802.11 \mathrm{~b}, \mathrm{~g}, \mathrm{n}(\mathrm{WIFI})$

Em 1997, é apresentado pelo IEEE (Institute of Electrical and Electronics Engineers) o primeiro padrão de referência de redes sem fio, o IEEE 802.11, que abrange as camadas, física e de enlace do modelo OSI. O conjunto de especificações para redes locais sem fio (WLAN - Wireless Local Area Network) baseada neste padrão denomina-se Wi-Fi, da abreviação do termo inglês "Wireless Fidelity".

\footnotetext{
${ }^{6}$ Para maiores informações: 〈http://www.zensys.com>
} 
Em 1999 surge uma nova especificação, o IEEE 802.11b, uma atualização que tinha como característica a possibilidade de estabelecer maior velocidade que o padrão anterior, transmissão nominal de dois para até $11 \mathrm{Mbps}$. Podendo chegar a um alcance de 50 metros em lugares fechados e 400 metros em lugares abertos, o padrão $802.11 \mathrm{~b}$ foi o primeiro a ser adotado em larga escala, sendo, portanto, um dos responsáveis pela popularização das redes Wi-Fi além de incluir aspectos da implantação do sistema de rádio e também incluir especificação de segurança.

Em 2003 foi disponibilizado o padrão 802.11g que permitiu trabalhar com uma taxa de transmissão de 54 Mbps totalmente compatível com o padrão IEEE 802.11b. Iniciado logo no ano seguinte, o padrão 802.11n foi finalizado em 2009. Sua principal característica, o uso de Multiple-Input Multiple-Output (MIMO), uma tecnologia de ramificações da área de estudo das Antenas Inteligentes. Essas representam um grupo de aparelhos dotados de sensores acoplados a um processador digital, que é capaz de interpretar o sinal captado pelos sensores por meio da aplicação de algoritmos que permitem um melhor aproveitamento do sinal, reduzindo o efeito destrutivo da interferência e maximizando o ganho na transmissão do referido sinal capaz de aumentar consideravelmente as taxas de transferência de dados mediante a combinação de várias vias de transmissão.

- IEEE $802.11 \mathrm{ac}$

Evolução do padrão de rede 802.11n, o Wi-Fi 802.11ac é a $5^{\text {a }}$ geração da tecnologia. Ela traz uma série de benefícios com transmissão de dados em 5 (cinco) GHz (gigahertz) até 300Mbps; em comparação, dispositivos que suportavam três fluxos espaciais no mesmo padrão suportariam velocidades de até $450 \mathrm{Mbps}$. Pode chegar realizar transmissões para computadores ou outros dispositivos que estejam a 200 metros de distância. Neste padrão a distribuição dos dados é mais inteligentes, as ondas não são propagadas de forma uniforme em todas as direções como nos padrões passados no ac os roteadores reforçam o sinal para as áreas aonde tem dispositivos conectados, essa tecnologia é chamada de Beamforming. Os ganhos de produtividade podem ser relevantes em locais de trabalho em que a demanda por acessos sem fio seja estratégico. Com esse recurso os problemas com os pontos cegos, ou seja, os locais aonde o sinal não chegava são parcialmente resolvidos.

- IEEE 802.15.1 
Outro padrão wireless é o Bluetooth, com especificações para a camada física e de enlace foi regulamentado pelo "Bluetooth SIG", que é formado por empresas como 3Com, Ericsson, IBM, Intel, Lucent, Microsoft, Motorola, Nokia, Toshiba e mais de 2000 companhias associadas. Esse trabalha na mesma faixa onde funcionam as redes Wi-Fi $(2,4 \mathrm{GHz})$, mais barato, mas com menor alcance de transmissão e menos consumo de energia. Levando-se em consideração o alcance das ondas de rádio, os dispositivos Bluetooth são classificados em três classes:

- Classe 3 - alcance de, no máximo, 1 metro;

- Classe 2 - alcance de, no máximo, 10 metros;

- Classe 1 - alcance de, no máximo, 100 metros.

A seguir, as principais tecnologias de rede para automação residencial utilizadas por eficiência e vantagens, dispostas na Tabela 2-2.

Tabela 2-2 Tabela de comparação das tecnologias (adaptada de Lugli e Sobrinho).

\begin{tabular}{|c|c|c|c|}
\hline $\begin{array}{c}\text { Norma } \\
\text { IEEE (Nome } \\
\text { de Mercado) }\end{array}$ & $\begin{array}{c}\text { 802.15.1 } \\
\text { Bluetooth }\end{array}$ & $\begin{array}{l}\text { 802.11.b } \\
\text { Wi-Fi }\end{array}$ & $\begin{array}{c}802.15 .4 \\
\text { ZigBee }\end{array}$ \\
\hline $\begin{array}{l}\text { Frequência } \\
\text { de operação. }\end{array}$ & $2,4 \mathrm{GHz}$ & $2,4 \mathrm{GHz}$ & $2,4 \mathrm{GHz}$ \\
\hline $\begin{array}{l}\text { Taxa de } \\
\text { comunicação } \\
(\mathrm{Kb} / \mathrm{ps})\end{array}$ & $1000-3000$ & 11000 & $20-250$ \\
\hline $\begin{array}{l}\text { Distância em } \\
\text { metros. }\end{array}$ & $\begin{array}{c}30 \text { (Classe 2) } \\
100+(\text { Classe } \\
1)\end{array}$ & $\begin{array}{c}100+ \\
\text { (Antenas } \\
\text { direcionais) }\end{array}$ & $\begin{array}{c}\text { 30-70, 100+ } \\
\text { (Com } \\
\text { amplificador } \\
\text { externo) }\end{array}$ \\
\hline $\begin{array}{l}\text { Número de } \\
\text { dispositivos. }\end{array}$ & 7 & 32 & $2 * 64$ \\
\hline $\begin{array}{l}\text { Autonomia } \\
\text { da bateria } \\
\text { (dias). }\end{array}$ & 1 á 7 & 0,5 a 5 & $100-1000+$ \\
\hline
\end{tabular}




\begin{tabular}{|l|c|c|c|}
\hline $\begin{array}{l}\text { Consumo na } \\
\text { transmissão. }\end{array}$ & $\begin{array}{c}45 \mathrm{~mA} \\
(\text { Classe 2) } \\
<150 \mathrm{~mA} \\
(\text { Classe 1) }\end{array}$ & $300 \mathrm{~mA}$ & $300 \mathrm{~mA}$ \\
\hline $\begin{array}{l}\text { Conveniência } \\
\text { para Controle } \\
\text { e Supervisão, } \\
\text { aplicações. }\end{array}$ & $\begin{array}{c}\text { Baixa } \\
\text { (Taxa c/ boa } \\
\text { conexãa, mas } \\
\text { (Taxa alta, } \\
\text { mas conexão } \\
\text { inicial lenta). }\end{array}$ & $\begin{array}{c}\text { compromisso lenta). } \\
\text { entre taxa e } \\
\text { custo de } \\
\text { operação). }\end{array}$ \\
\hline $\begin{array}{l}\text { Vantagens } \\
\text { relativas. }\end{array}$ & $\begin{array}{c}\text { Custo, } \\
\text { Flexibilidade }\end{array}$ & $\begin{array}{c}\text { Velocidade, } \\
\text { Flexibilidade }\end{array}$ & $\begin{array}{c}\text { Potência, } \\
\text { Custo }\end{array}$ \\
\hline
\end{tabular}

As mensagens trocadas entre cliente Android e o Servidor de Automação de Residencial - SAR apresentam parâmetros específicos, descritos na

Tabela 2-3 a seguir:

Tabela 2-3 Parâmetros específicos entre cliente Android e o servidor de automação residencial (Adaptada de EUZÉBIO, 2011).

\begin{tabular}{|l|l|}
\hline Tipo: & Indica a operação a ser realizada; \\
\hline Endereço: & Identificação do controlador presente na rede de dados; \\
\hline Conteúdo: & Dado da operação a ser realizada; \\
\hline Opcional: & Identifica a lâmpada presente no controlador, quando necessário. \\
\hline
\end{tabular}

Para essa aplicação foi utilizado o padrão WiFi 802.11b, pelas possibilidades de segurança que esse oferece e importância em uma aplicação residencial. O alcance total da rede foi um fator avaliado, pois leva em consideração que o usuário possa querer realizar alguma ação próxima a sua casa. Assim como o alcance da rede, o consumo médio de bateria gasta pelos dispositivos móveis quando o WiFi está habilitado é de essencial importância pois, é por meio deles que o controle domótico é realizado. A possibilidade de controlar a residência de qualquer ambiente que possua internet e a quantidade de dispositivos que podem se conectar simultaneamente a rede também foram levados em consideração.

\subsection{Cliente Android $x$ SAR}

\subsubsection{Cliente Android}


O cliente Android consiste em uma aplicação disponível para smartphones com sistema operacional Android embarcado. Quando conectado à rede IP, a aplicação estabelece conexão com o servidor e envia comandos via protocolo HTTP ou HTTPS com informações de controle para o servidor.

O Android é considerado um sistema operacional integrado à pilha de software. Esta consiste em sistema operacional, middleware, interface amigável e aplicações conforme pode ser verificado na figura 2-2. Possui código aberto desenvolvido na linguagem de programação Java, que controla o dispositivo via bibliotecas. Permite flexibilidade para que os próprios usuários possam desenvolver seus aplicativos.

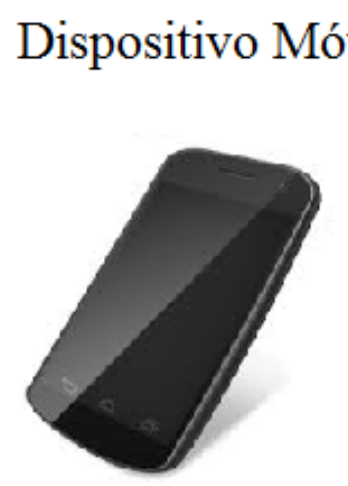

S O Android

APP $H A$

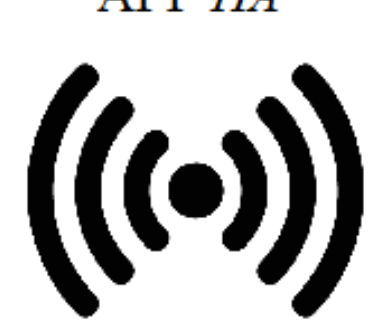

\section{el}

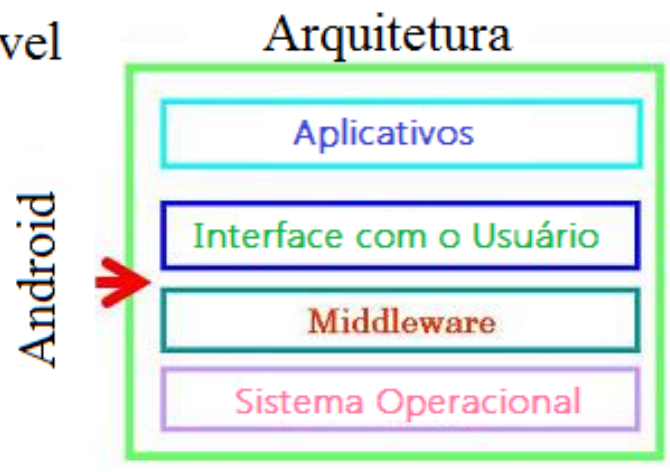

Casa atomatizada

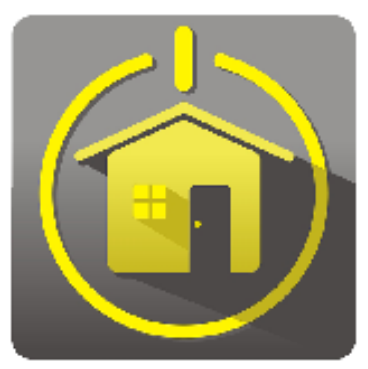

$\mathrm{SAR}+\mathrm{APP}+$

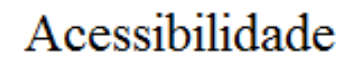

Rede

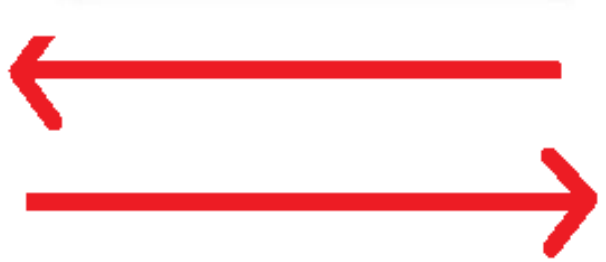

Figura 2-2 - Arquitetura utilizando Android (Adaptada de: MORIMOTO, 2009)

Os sistemas de automação residencial atuais permitem a utilização de diversos tipos de interfaces, dentre elas os dispositivos móveis escolhidos para ser a interface entre o sistema de automação domótica e o usuário que pode ser deficiente visual ou não. Aplicações específicas para telefones inteligentes têm a usabilidade como principal vantagem quando comparadas com páginas web.

A interface permite abstrair do usuário os outros elementos do sistema, dando-lhe a noção de estar conectado diretamente ao equipamento da residência. O software não necessita 
estar constantemente ligado ao servidor, apenas quando for enviar algum comando (EUZÉBIO, 2011).

\subsubsection{SAR - Servidor de Automação Residencial}

Para controlar o sistema de automação residencial existe, na maioria das vezes, um centralizador, que é um componente que atua como servidor responsável por receber e transmitir informações tanto para o cliente Android quanto para sensores e atuadores. Capaz de interpretar uma informação e executar determinada ação mediante o recebimento de uma mensagem, esse servidor transfere os comandos entre as interfaces de controles e os controladores dos dispositivos.

O Servidor de Automação Residencial - SAR deve permanecer constantemente em operação e conectado à rede IP. Sua principal função no sistema é interpretar os comandos do cliente, convertê-las para o protocolo da rede de dados e enviá-las para os controladores dos equipamentos da residência. $\mathrm{O}$ caminho inverso também é verdade, pois os controladores respondem à solicitação do servidor que por sua vez repassa ao cliente (EUZÉBIO, 2011).

Outra função do servidor é manter-se atualizado quanto aos dispositivos da rede de dados, requisitando regularmente aos controladores as informações sobre o estado dos equipamentos controlados pelo mesmo. Também é função do SAR autenticar o usuário no sistema, onde apenas após esta ação os comandos de controle do cliente são repassados adequadamente ao controlador específico (EUZÉBIO, 2011).

No caso do sistema de automação apresentado nesse trabalho há um servidor centralizador - servidor de automação residencial composto por uma placa microcontrolada Arduino MEGA 2560 e um módulo Ethernet que é devidamente encaixado no Arduino segundo a figura 2-3. Também é necessário um roteador WiFi para que o sistema esteja disponível em toda residência. As interfaces de controle são construídas pensando na acessibilidade e integração do deficiente visual com o sistema. O sistema é acessado por dispositivos móveis que são configurados com os mecanismos de respostas escolhidos pelo usuário tornando-o de fácil acesso e resposta. 


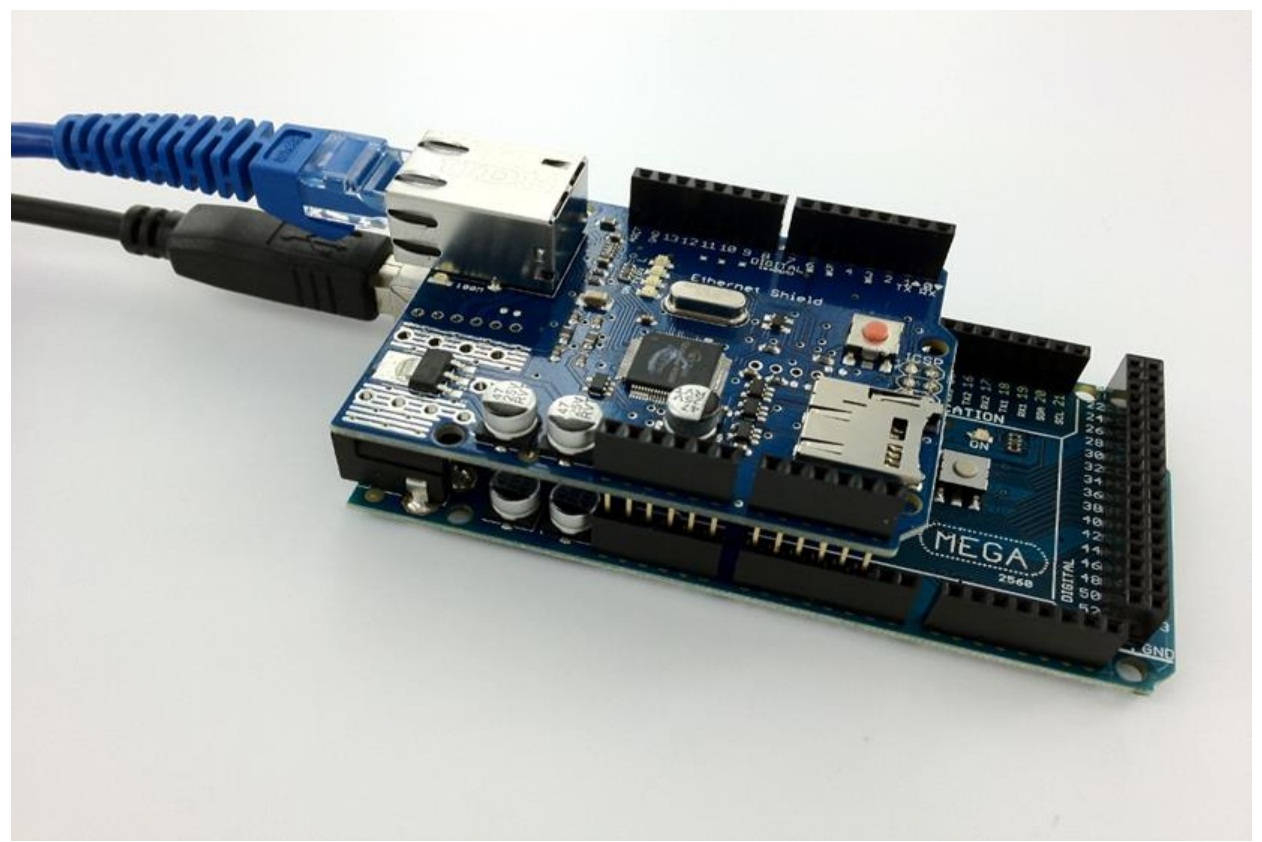

Figura 2-3 Placa Microcontrolada Arduino 2560 com Módulo Ethernet.

\subsubsection{Questões a respeito da segurança da aplicação}

A gestão adequada dos sensores, atuadores e dispositivos móveis geram conforto, acessibilidade e consequentemente a segurança dos sistemas domóticos. Sendo o sistema em questão voltado a automação residencial, gerenciado por uma interface acessível dedicada a atender aos usuários com e sem deficiência visual por meio de um aplicativo para dispositivos móveis. É fundamental proporcionar a segurança do sistema e dos usuários a fim de que o utilizador permaneça protegido contra ataques provenientes de pessoas estranhas ao sistema e que possam vir a causar danos ao usuário e/ou à sua residência.

É de fundamental importância para a segurança do sistema e consequentemente segurança do usuário, que apenas utilizadores com autenticação possam acessar o sistema após serem bem instruídos e informados por meio do manual do sistema (Apêndice A). Como o sistema é acessível a UDV, é muito importante frisar que esse está embasado em pilares considerados fundamentais: gestão e controle de parâmetros de segurança técnica, tais como: fogo, fugas de gás, inundação, dentre outros.

Outro fator importante a ser considerado, são as informações que entram e saem por meio da rede utilizada para acionar os dispositivos. Por se tratar de uma residência, esse fator se torna mais delicado, pois os UDV podem ser mais suscetíveis a riscos de invasões. Entende-se por segurança da informação, o conjunto de medidas de controles e política de 
segurança que objetivam a proteção das informações, quer sejam dos clientes ou empresas, quer sejam controlando os riscos de revelação ou alteração por pessoas não autorizadas.

"Os sistemas ativos de segurança visam evitar que investidas estruturadas sejam feitas contra uma rede ou um sistema específico. Eles independem que pessoas mal intencionadas consigam explorar brechas e vulnerabilidade com o objetivo de penetrar no sistema com objetivos escusos." (TORRES, 2001)

De acordo com a NBR ISO/IEC 17799 (2005) define SI como: a política de proteção existente sobre as informações de uma determinada organização de vários tipos de ameaças para garantir a continuidade do negócio, minimizar riscos, maximizar o retorno sobre os investimentos e as oportunidades do negócio. Ela pode estar guardada para uso restrito ou exposta ao público para consulta ou aquisição.

A Tabela 2-4 a seguir mostra os principais sensores, suas aplicações e acessibilidade. Dessa forma, o usuário pode escolher os sensores que melhor atendem suas necessidades.

Tabela 2-4 Sensores típicos para o setor residencial e suas aplicações

\begin{tabular}{|c|c|c|c|c|c|c|c|c|c|c|c|c|c|c|c|}
\hline Função & \multicolumn{5}{|c|}{ Energia } & \multicolumn{4}{|c|}{ Segurança } & \multicolumn{4}{|c|}{ Conforto } & \multicolumn{2}{|c|}{ Acessibilidade } \\
\hline Sensores & 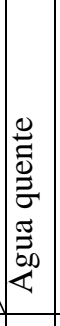 & 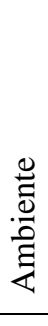 & 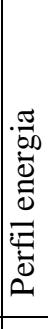 & 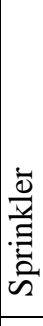 & 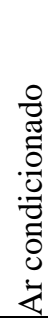 & 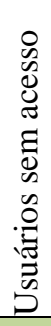 & 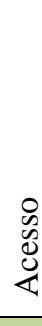 & 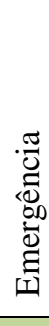 & 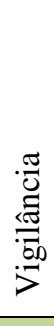 & 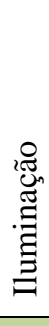 & 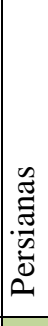 & 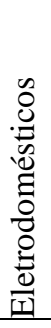 & 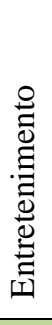 & 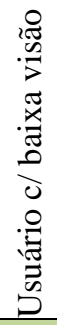 & 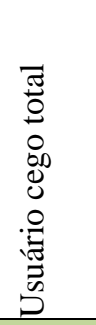 \\
\hline Presença & & & & & & & & & & & & & & & \\
\hline Temperatura & & & & & & & & & & & & & & & \\
\hline Portas/ janelas & & & & & & & & & & & & & & & \\
\hline Humidade & & & & & & & & & & & & & & & \\
\hline Gás & & & & & & & & & & & & & & & \\
\hline Luminosidade & & & & & & & & & & & & & & & \\
\hline $\begin{array}{l}\text { Corrente } \\
\text { elétrica }\end{array}$ & & & & & & & & & & & & & & & \\
\hline $\begin{array}{l}\text { Temperatura } \\
\text { do ambiente }\end{array}$ & & & & & & & & & & & & & & & \\
\hline Fumaça & & & & & & & & & & & & & & & \\
\hline
\end{tabular}


Dentre as áreas de segurança a área de detecção de intrusão é uma área em expansão. Para garantir que os sistemas possuam funcionamento contínuo e correto, mesmo na presença de vulnerabilidades e falhas, são aplicados os chamados Sistemas de Detecção de Intrusão (IDS).

Muito utilizado em monitoramento nas atividades de uma rede, o IDS monitora dinamicamente as ações em um dado ambiente e decide que ações constituem ou não um ataque em potencial, esse ataque pode ser realizado por outro sistema ou por hackers. Um IDS pode ser definido como um detector que processa informações oriundas de um sistema a ser protegido (DEBAR, 1990 pag. 805-822). O IDS é composto por sensores que geram segurança ao monitorar, por console, eventos e alertas e um mecanismo central que grava os eventos registrados na base de dados e usa um sistema de regras para gerar alertas a partir dos eventos de segurança recebidos.

\subsection{Ferramenta de desenvolvimento parcialmente reconfigurável.}

Uma API (Application Programming Interface) é uma série de funções que permitem ao programador acoplar novas funcionalidades a um programa já existente. Embora alguns motores gráficos sejam multiplataforma e permitam a troca de APIs (e.g, a API de renderização), a escolha de um motor é uma tarefa difícil. Mais difícil ainda é substituir o motor utilizado em uma aplicação de realidade virtual, pois sua arquitetura pode ser consideravelmente diferente (Gelatti, 2002). Por vezes, o motor adotado é de difícil aprendizado e também pode acarretar problemas aos sistemas com ele desenvolvidos, atrelando-os fortemente à tecnologia utilizada em seu desenvolvimento ou a uma plataforma específica (Maia et al., 2003).

Para facilitar o trabalho de desenvolvedores, empresas disponibilizam uma série de APIs em conjunto, formando um kit de desenvolvimento de software (SDK), que também contém algumas outras bibliotecas e ferramentas de desenvolvimento necessárias para construir, testar e depurar os aplicativos (ANDROID, 2016). A JBits é um conjunto de classes Java que fornecem uma API para manipular o arquivo de configuração da família de FPGAs Virtex. Essa interface opera tanto em arquivos de configuração gerados pelas ferramentas de projeto da Xilinx quanto em arquivos de configuração lidos do hardware (MCMILLAN, 1999). A escolha de uma determinada API pode simplificar o desenvolvimento de aplicações, mas também traz limitações inerentes dessa API. 


\subsection{Aspectos sobre Interfaces $x$ Interação}

Em um ambiente informatizado é a interface que apresenta painéis com informação, dados, controles, comandos e mensagens, sendo por meio dessas apresentações que a interface solicita a entrada de dados de controle, assim como de comandos de controle de usuário (CYBIS, BETIOL e FAUST, 2007, p.17). Outro conceito é dado por Rocha e Baranauskas (2003), que define interface como uma superfície de contato que reflete as propriedades físicas das partes que interagem as funções a serem executadas e o balanço entre poder e controle. Para Moran (1981), interface é "parte de um sistema computacional com a qual a pessoa entra em contato - física, perceptiva ou conceitualmente".

A interface é a parte visível do sistema e, quando bem projetada, gera sentimentos positivos que levam a uma boa interação homem-computador-IHC. Uma boa interface torna a interação com o sistema mais fácil de aprender e usar (com usabilidade). Em outras palavras, a interface pode influir na produtividade do usuário, que nem sempre prefere um sistema com mais recursos ou eficiência do ponto de vista computacional. A figura 2-4 exemplifica como é o processo de interação entre o homem e o computador. No caso de um UDV, esta interface tem que ser projetada a fim de adequar-se a esse usuário, trazendo a acessibilidade e a autonomia com respeito ao sistema.

Para um bom entendimento do desenvolvimento de uma interface com qualidade de usabilidade (facilidade de uso), é necessário conhecer as necessidades do usuário, sem adaptar a interface do sistema ao usuário.

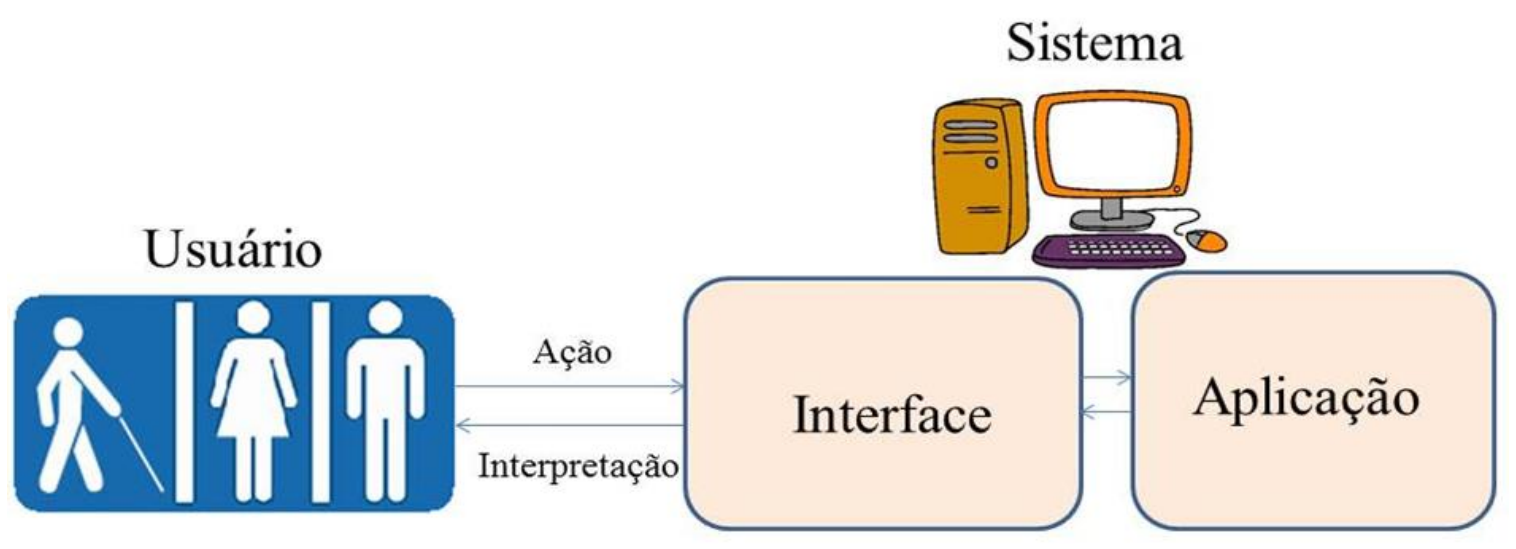

Figura 2-4 - O Processo de Interação Homem - Computador (Adaptada de PRATES. Barbosa, 2003). 
Dessa maneira, a IHC se ocupa do estudo do design, avaliação e implementação de sistemas computacionais interativos para uso humano e os principais fenômenos ao seu redor. Nesse sentido, devem ser considerados quatro elementos básicos segundo Shackel (1986) no contexto de usabilidade: (a) o sistema, (b) os usuários, (c) a tarefa e (d) o ambiente. A figura 2-5 mostra algumas disciplinas que estão envolvidos em IHC.

Esses quatro elementos estão envolvidos em dois processos importantes: (a) a interação usuário-sistema e (b) o desenvolvimento do sistema. A interação é o processo de comunicação entre pessoas e sistemas interativos (Preece et al., 1994). Nesse sentido, de acordo com Carroll (1991) a chave principal para a IHC é entender e facilitar a criação de interfaces de usuários, considerando-a como sendo uma área interdisciplinar.

Nesse processo, tanto o usuário como o sistema trocam turnos em que um "fala" e o outro "ouve", interpretando e realizando uma ação. De acordo com Gomes Filho (2006, p.15), interfaces são duas ou mais especialidades de design que se relacionam para desenvolver um produto. Barbosa e Silva (2010) complementam indicando que todos os elementos envolvidos no processo de interação são vinculados à interface e vice-versa formando assim, um contato conceitual que envolve a interpretação do usuário daquilo que ele percebe. Nesse caso, a interface é o nome dado para toda porção de um sistema com o qual um usuário mantém contato ao utilizá-lo, tanto ativa quanto passivamente, englobando software e hardware (dispositivos de entrada e saída, tais como: teclados, mouse, tablets, monitores, impressoras entre outros).

Os principais objetivos para realizar a avaliação de sistemas interativos são os seguintes:

- Identificar as necessidades de usuários e verificar o entendimento dos projetistas sobre essas necessidades;

- Identificar problemas de interação ou de interface;

- Investigar como uma interface afeta a forma de interação dos usuários;

- Comparar alternativas de projetos de interface;

- Alcançar objetivos quantificáveis em métricas de usabilidade e

- Verificar conformidade com um padrão ou conjunto de heurísticas. 


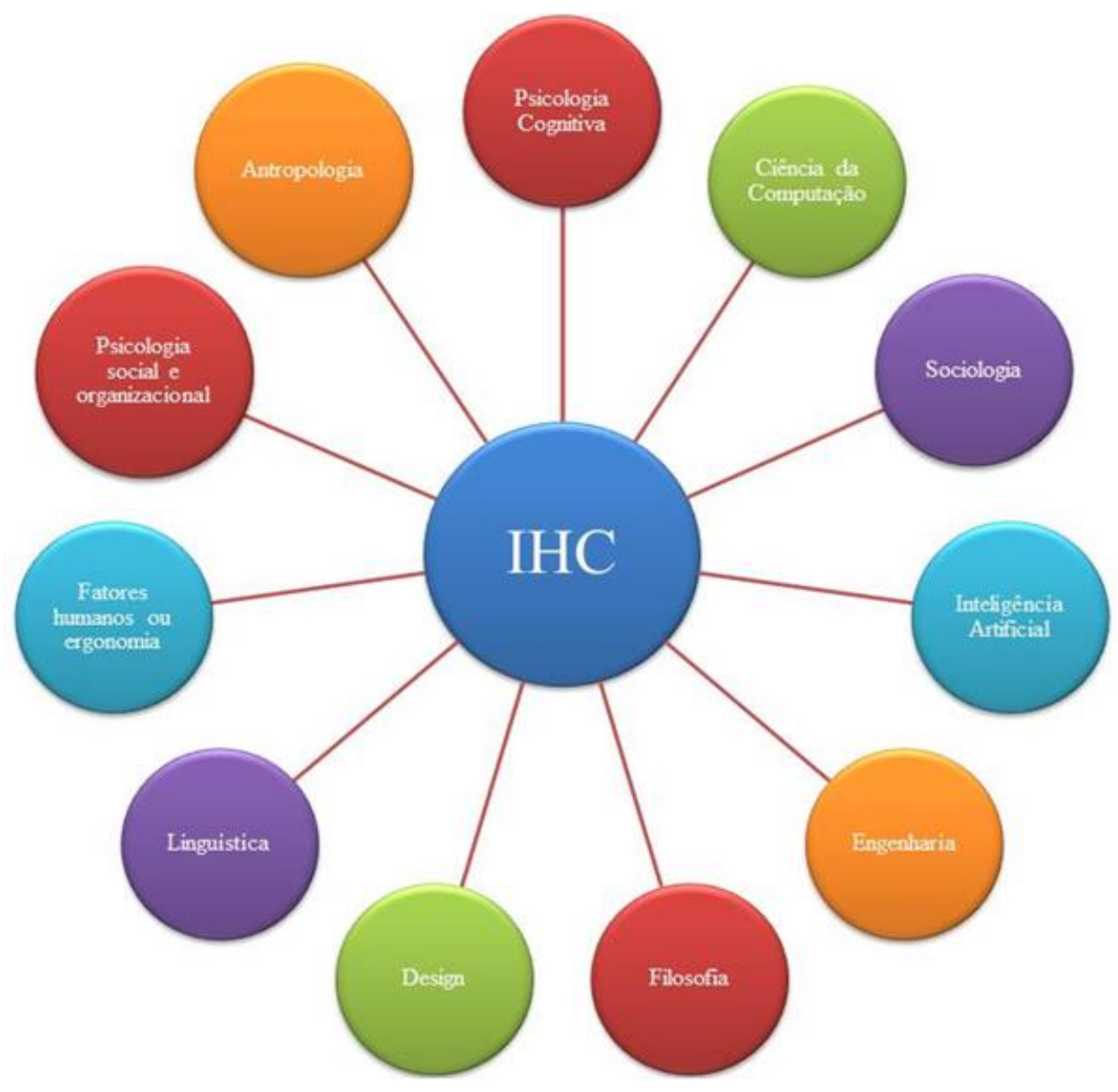

Figura 2-5 - Disciplinas que contribuem em IHC (adaptada de: ROCHA, 2000).

Considerando-se os aspectos supracitados do processo de interação usuário-sistema, o segundo processo citado (desenvolvimento do sistema) deve ser abordado do ponto de vista metodológico envolvendo recomendações geradas a partir de uma avaliação de sistemas interativos. Para tanto, é necessário desenvolver uma pesquisa para saber o comportamento, as emoções e as expectativas que o usuário tem do sistema, tornando-o mais acessível e voltado às suas especificidades.

\subsubsection{Design para usuários com deficiência visual}

O design tem como função suprir necessidades dos indivíduos, porém muitas vezes há o esquecimento das pessoas com deficiências. Para aquelas que apresentam a deficiência visual, a atenção deve estar no design emocional. É importante estudos para que o design seja agradável e acessível. Para esse trabalho, foi realizado um pré-teste com usuários comuns em ambientes virtuais para que eles vivenciassem as necessidades de PDV, auditiva e física.

\subsubsection{Design Universal}


O design universal ou design para todos está presente na legislação brasileira, traduzido para desenho universal e carrega heranças de seu significado no design arquitetônico:

“(...) desenho universal significa a concepção de produtos, ambientes, programas e serviços a serem usados, na maior medida possível, por todas as pessoas, sem necessidade de adaptação ou projeto específico. O desenho universal não excluirá as ajudas técnicas para grupos específicos de pessoas com deficiência, quando necessárias..." (BRASIL, 2009).

Nesse sentido, o design universal reconhece a força legal, econômica e social de tratar das necessidades comuns das pessoas com e sem deficiência buscando assim, soluções que não discriminem e que simplifiquem a vida de todos (CONNELL et al., 1997).

\subsubsection{Design Emocional}

No contexto real, o design está voltado para as experiências e emoções do usuário final da criação. Assim, o estudo desse utilizador se faz essencial para a criação do design dos sistemas. Por meio do design, o projetista é capaz de despertar uma emoção específica nos usuários. Segundo Demil et al. (2009), uma das maiores causas de emoções relacionadas à felicidade e à alegria em relação ao design como projeto é a consistência do motivo da aquisição de um produto. Assim, o contentamento e a satisfação envolvem as avaliações de: (a) consciência de motivo e (b) expectativa confirmada (DEMIR et al., 2009, p. 44-45).

Dessa maneira, para que essas emoções sejam positivas são realizadas pesquisas diretas com usuários. Por esse motivo, unindo a psicologia e o design é possível certificar e desenvolver métodos que sirvam para comprovar que as emoções podem ser obtidas por meio dos projetos. Isso não significa que a única forma de se lidar com emoções em design seja através dessa perspectiva (psicologia-design-pesquisa), porém existe um consenso internacional sobre a tríade psicologia, design e pesquisa, assumindo que a emoção pode ser previsível e controlável (pelo menos em parte), podendo assim atuar na modelagem das experiências emocionais desejadas pelas pessoas no projeto de design (TONETTO et COSTA, 2011, p. 133)

Segundo Norman (2004), os seres humanos são os mais complexos de todos os animais. Os estudos do autor sugerem que as emoções estão relacionadas a três níveis de processamento cerebral: (a) a "automatic prewired layer", chamado de nível visceral; (b) a parte que contém os processos cerebrais que controlam o comportamento cotidiano, denominada nível comportamental; e (c) a parte contemplativa do cérebro, o nível reflexivo. 
Nesse caso, cada nível tem um papel diferente no funcionamento das pessoas e requer estratégias de design distintas.

De acordo com as diferentes estruturas utilizadas pelo cérebro podemos ter diferentes níveis de design. O nível visceral, que faz julgamentos rápidos - é bom ou é ruim?- sendo praticamente automático ou pré-programado. Os seres humanos recebem poderosos sinais emocionais da natureza e os interpretam automaticamente no nível visceral. O design visceral tem como base a aparência do objeto, a sua estética e, consequentemente, pretende despoletar no consumidor um impacto emocional e instintivo, desencadeando dessa forma uma ação correspondente (Norman, 2004). Nesse contexto Cacioppo e Gardner (1999), definem que as pessoas são construídas para oferecer uma avaliação subjetiva do significado dessas propriedades e não para responder com propriedades objetivas dos estímulos.

O nível comportamental envolve os processos cerebrais que controlam a grande maioria de nossas ações como dirigir um carro, andar de bicicleta ou dançar. O conceito de design comportamental é totalmente ligado ao uso em si. Neste caso, aparência e racionalidade não são importantes, mas desempenho sim. Nesse caso, são relevantes a função, a compreensibilidade, a usabilidade e a sensação física.

Finalmente, o nível reflexivo refere-se à compreensão, à interpretação, ao raciocínio e à parte contemplativa do cérebro - é nesse nível que são processadas ações como apreciar uma obra de arte, torcer por um time de futebol ou sentir saudades de alguém. O design reflexivo é bastante amplo, pois o mesmo cobre mensagem, cultura e significados. Trabalha essencialmente com autoimagem e memória (Norman, 2004). Adicionalmente, o mesmo afirma que não existem formas absolutas de desencadear reações emocionais nas pessoas revelando que a relatividade da interpretação da experiência determina a emoção. A figura 2-6 demostra como níveis reflexivo, comportamental e visceral estão intimamente interligados aos sensores naturais do corpo humano gerando controle do mesmo. 

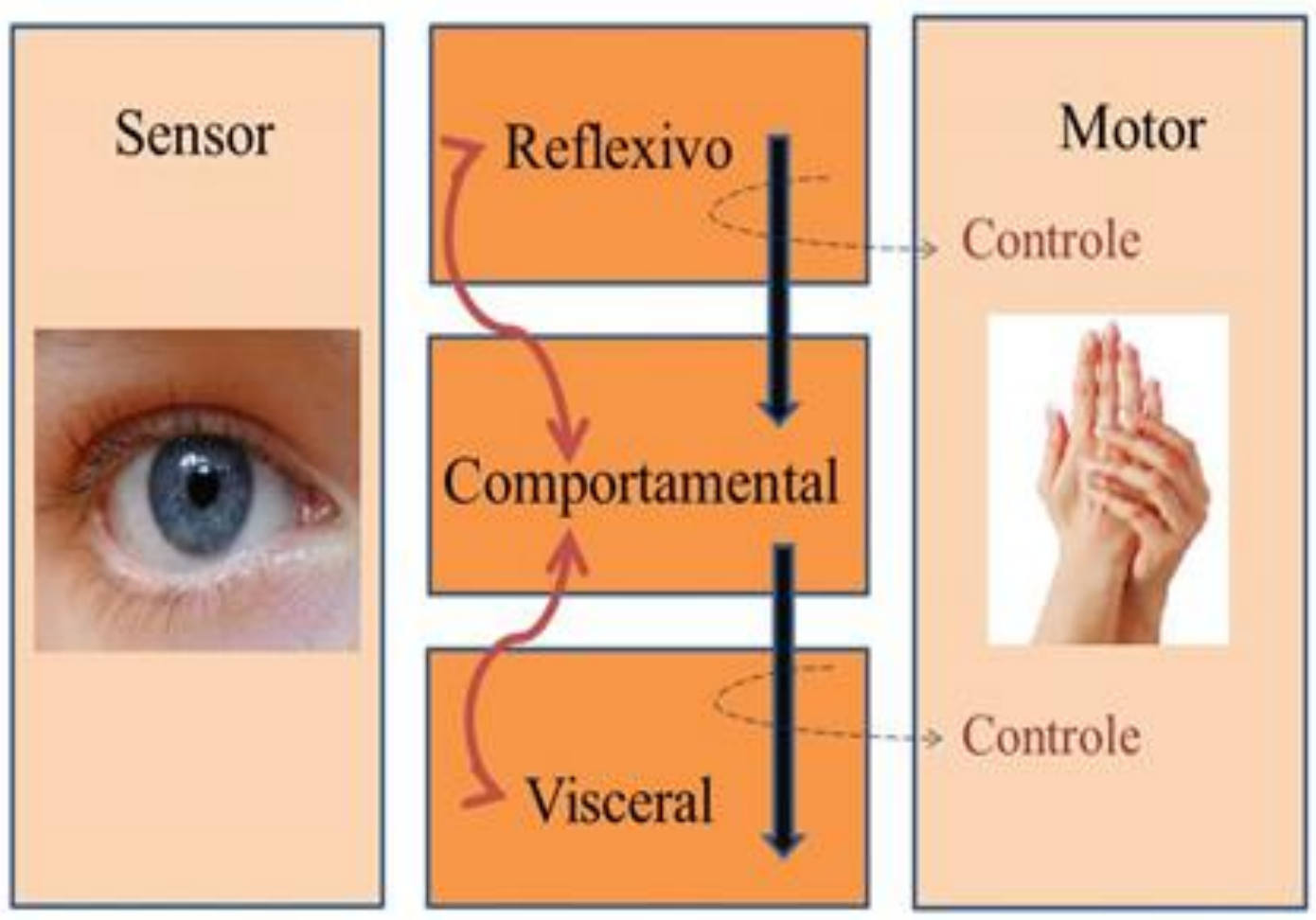

Figura 2-6 - Níveis de processamento da informação (adaptada de NORMAN, 2004).

No contexto desse trabalho, é dada importância à dimensão emocional do usuário levando-se em consideração que para cada nível do design emocional têm-se tarefas e atividades distintas baseadas no usuário. É importante que estes usuários sejam ouvidos e suas necessidades sejam atendidas, a fim de que essas tarefas possam ser realizadas de forma autônoma e com a acessibilidade que cada grupo de deficiência necessita.

As emoções que cada usuário deposita para realizar uma tarefa do sistema devem ser levadas em consideração na criação de interfaces dedicadas a atender cada tipo de público. Por este motivo, esse trabalho estabelece um método de pesquisa sobre as necessidades dos usuários no contexto dos conceitos discutidos nessa seção, que tem por base pré-testes, entrevistas, questionários e observação de um conjunto de usuários com diferentes graus de deficiência visual, submetidos a processos de navegação em interfaces previamente definidas.

Adicionalmente, foi definida a utilização do design emocional considerando que o design comportamental e o design reflexivo são mais ligados a aspectos objetivos e descartando em parte ou totalmente as particularidades específicas dos usuários. Dessa maneira, tem-se como objetivo definir técnicas que auxiliem na acomodação e na expressão das diferenças dos usuários deficientes visuais. Essa técnica terá como foco os melhores 
métodos para interface dentro da domótica, organizadas de acordo com arquétipos representativos do perfil dos UDV, as personas.

\subsection{Aspectos sobre o tema de métodos e pesquisa científica no contexto desse trabalho}

As pesquisas científicas podem ser classificadas, quanto à natureza, em dois tipos básicos: qualitativa e quantitativa e um misto dos dois tipos. A pesquisa quantitativa trabalha com indicadores numéricos e critérios fixos, que visam gerar projeções a população. Segundo Richardson (1999), a pesquisa quantitativa emprega quantificação tanto nas coletas de informações quanto no tratamento delas por meio de técnicas estatísticas. Como na pesquisa quantitativa, as respostas de alguns problemas podem ser inferidas para o todo, então a amostra deve ser muito bem definida caso contrário, podem surgir problemas ao se utilizar a solução para o todo (MALHOTRA, 2001). A pesquisa quantitativa acredita que, de acordo com Demo (2002, p.7), "a ciência prefere o tratamento quantitativo porque ele é mais apto aos aperfeiçoamentos formais: a quantidade pode ser testada, verificada, experimentada, mensurada [...]". Já os adversários da perspectiva positivista e quantitativa "propõem respeitar mais o real" (LAVILLE \& DIONNE, 1999, p.43) e abrem caminho para a pesquisa qualitativa em que se busca abdicar, total ou quase totalmente das abordagens matemáticas no tratamento dos dados trabalhando, preferencialmente, com a compreensão das motivações, percepções, valores e interpretações das pessoas, além de procurar extrair novos conhecimentos. Para Moreira (2002), a diferença entre a pesquisa quantitativa e a qualitativa vai além da simples escolha de 27 estratégias de pesquisa e procedimentos de coleta de dados representando na verdade, posições epistemológicas antagônicas.

A abordagem de cunho qualitativo buscando o significado do dado baseia-se na percepção do fenômeno dentro do seu contexto. De acordo com Bogdan \& Biklen (2003), o conceito de pesquisa qualitativa envolve cinco características: ambiente natural, dados descritivos, preocupação com o processo, preocupação com o significado e processo de análise indutivo. Para Gil (1999), essa abordagem aprofunda as questões relacionadas ao fenômeno em estudo e suas relações, mediante a máxima valorização do contato direto com a situação estudada, buscando-se o que era comum, mas permanecendo, entretanto, aberta para perceber a individualidade e os significados múltiplos. 
As técnicas não probabilísticas e não aleatórias são técnicas em que há uma escolha deliberada dos elementos da população, que não permitem generalizar os resultados das pesquisas para a população, pois amostras não garantem a representatividade dessas. De acordo com determinado critério, é escolhido intencionalmente um grupo de elementos que comporão a amostra. $\mathrm{O}$ pesquisador se dirige intencionalmente a grupos de elementos dos quais deseja saber a opinião.

Esta pesquisa foi embasada na junção das técnicas qualitativas e não probabilísticas. Foi utilizada a técnica qualitativa visando analisar os dados coletados e observados durante os pré-testes a fim de buscar os problemas individuais e coletivos de acessibilidade com celulares e computadores que fossem comuns entre as pessoas entrevistadas. A técnica não probabilística visou atender intencionalmente por questões legais apenas os usuários acima de 18 anos, que pudessem assinar por extenso o seu nome, alfabetizados, que utilizavam o sistema operacional Android, que fossem PDV e moradores do Distrito Federal.

\subsubsection{Cálculo da amostra}

Para o cálculo de uma população em que não se pode mensurar o tamanho da amostra aleatória $(N)$, o tamanho mínimo simples mensurado pode ser determinado por meio do cálculo de $(n o)$ onde o erro amostral tolerável é dado por (Eo). Entende-se por erro amostral tolerável a diferença tolerada, pelo pesquisador entre o valor que a estatística acusa e o verdadeiro valor do parâmetro que se deseja estimar (Barbetta, 1999). A fim de se ter uma primeira aproximação para o cálculo do tamanho da amostra, utiliza-se a probabilidade do valor do parâmetro no estudo pertencente ao intervalo centrado na estimativa estatística do parâmetro e limites determinados pelo erro amostral tolerado, nesse caso, a probabilidade pode ser de 0,95 ou $95 \%$ (nível de confiança) e a variância populacional no caso de maior heterogeneidade da população, ou seja, quando a proporção do evento na população em estudo é de 0,5, devido ao fato de ser essa a pior situação possível em termos de variabilidade populacional onde é utilizada a Equação ( I ) dado por:

$$
n o=\frac{1}{E o^{2}}
$$

onde:

no = Tamanho mínimo simples mensurado;

$E o=$ Erro amostral tolerável. 
Na pesquisa em questão sabe-se a quantidade de cegos do Brasil, porém, como a amostra tem um tamanho inferior ao total do universo, haverá certo nível de erro nos dados que serão observados. Para calcular o tamanho mínimo de amostra que é preciso para o caso em questão foi utilizada a Equação ( II ).

$$
n=\frac{N \cdot Z^{2} \cdot p \cdot(1-p)}{Z^{2} \cdot p \cdot(1-p)+e^{2} \cdot(N-1)}
$$

onde:

$n=\mathrm{O}$ tamanho da amostra que se quer calcular;

$N=$ Tamanho do universo;

$Z=$ É o desvio do valor médio que é aceito para alcançar o nível de confiança desejado;

$e=$ É a margem de erro máximo que se quer admitir (p.e. 5\%);

$p=$ É a proporção que se espera encontrar.

Depois do cálculo da amostra necessária para realizar a pesquisa, pode-se começar a fase dos pré-testes.

\subsection{Definição de pré e pós - testes}

Pré e pós-testes são utilizados para medir o conhecimento adquirido pelos participantes em uma formação.

\subsubsection{Pré e Pós - testes}

O pré-teste é um conjunto de perguntas feitas aos participantes antes do início da formação com a finalidade de determinar o seu nível de conhecimento sobre o conteúdo que será ensinado. Segundo GIL (1999), o pré-teste é um instrumento de coleta de dados que tem por objeto assegurar-lhe validade e clareza dos termos com precisão.

Nesse sentido, o pré-teste avalia cada item sob três aspectos: (a) grau de dificuldade, (b) nível de discriminação que é o quanto o item consegue diferenciar as pessoas que sabem ou não, e (c) probabilidade de acerto ao acaso, além da proporção de pessoas que escolhem 
cada alternativa de resposta oferecida na prova. Uma prova para o pré-teste deve reunir itens de difícil, média e fácil resolução em que o número de questões pode variar a cada teste.

Nesse trabalho, por meio de um pré-teste foram adquiridos os dados das entrevistas estruturadas que possibilitaram estabelecer uma coleta mais rigorosa das necessidades dos usuários com deficiência. O pós - teste resultou em um aplicativo acessível capaz de atender a maioria das necessidades apontadas durante os pré - testes. Ainda encontra-se na fase de testes esse aplicativo.

A figura 2-7 mostra onde o método de acessibilidade que será utilizado. Assim, dentro da IHM Acessível no ambiente de UDV será utilizado o método em questão. O diagrama esclarece que, de forma alguma, essa interface excluirá os demais usuários.

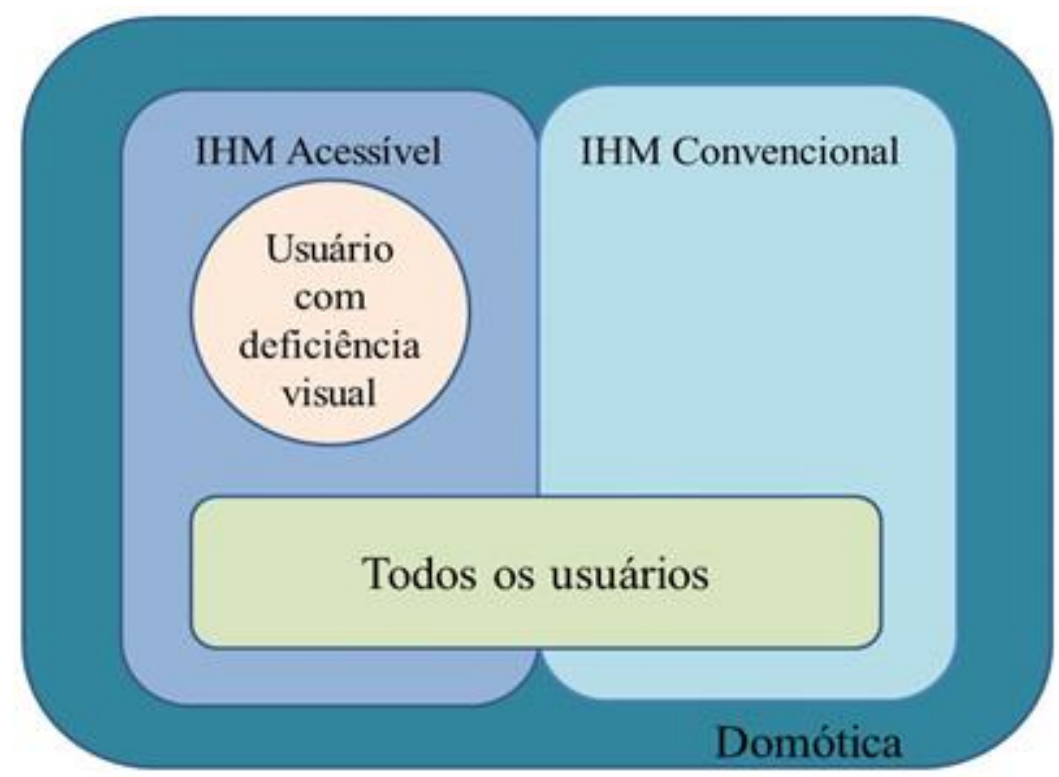

Figura 2-7 - Diagrama Correlacionando IHM Acessíveis e Convencionais

Utilizando a normatização W3C é possível solucionar a maioria dos problemas de falta de acessibilidade de interface levantados durante a fase pré-teste. Reforçando-se que essa normatização em nada interfere na estética da interface para os usuários sem deficiência visual. Outros pontos como tempo de resposta, qualidade da pesquisa, qualidade da informação devolvida ao usuário foram abordados e devem ser levados em consideração.

Após a criação da interface e sabendo o que precisa ser automatizado no ambiente domótico, é necessário criar um modelo baseado nessa interface acessível com sensores e atuadores que melhor atendem às necessidades dos UDV, prezando sempre pela segurança, 
pelo conforto, pela gestão de energia e pela comunicação. A figura 2-8 mostra o modelo para os níveis da automação.

\subsubsection{Modelos de Domótica de acordo com o nível de automação}

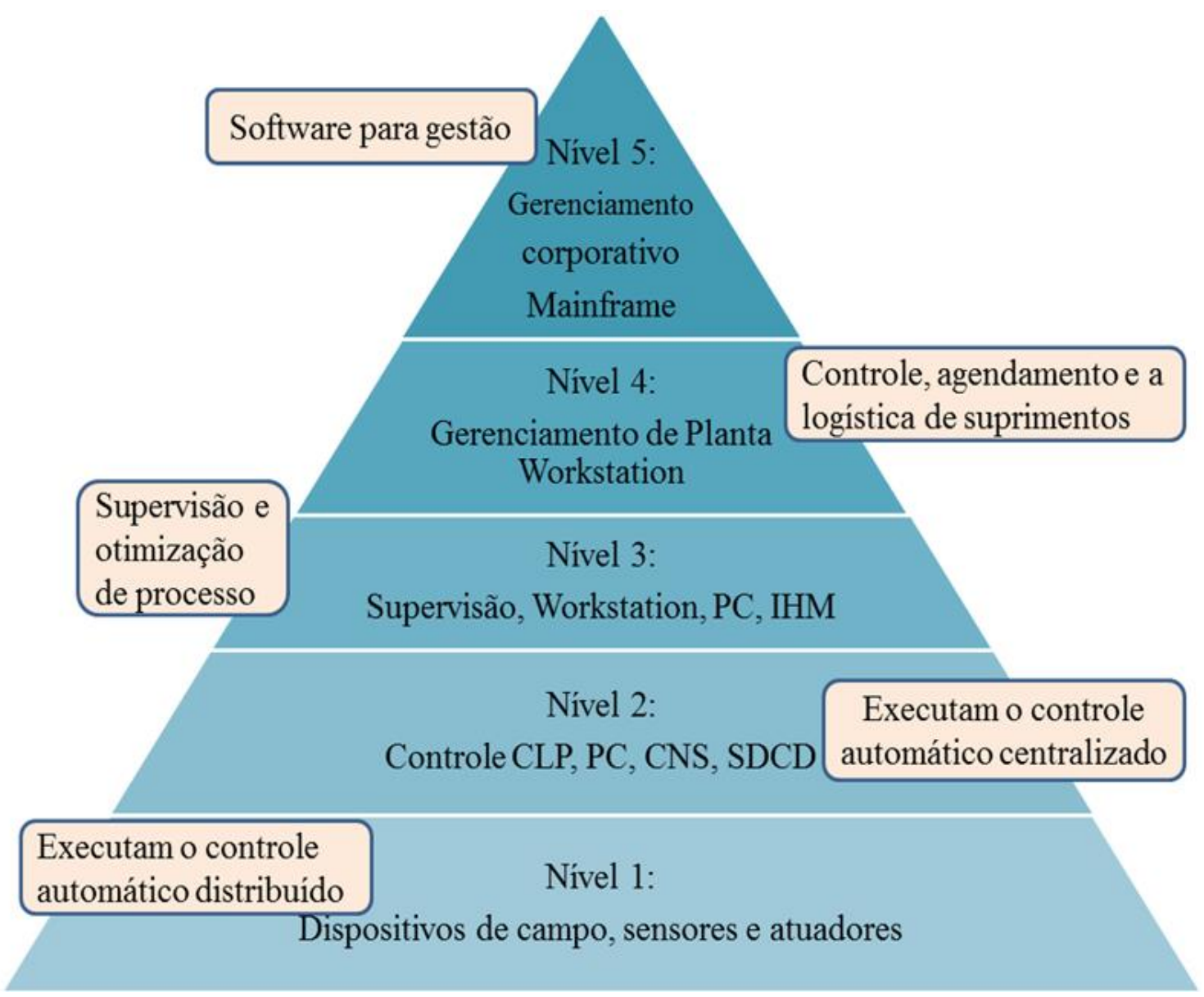

Figura 2-8 Níveis da pirâmide de automação (Adaptada de: www.mecatronicaatual.com.br).

Algumas redes industriais trabalham com o controle automático distribuído. Nesse, os dados são transmitidos ciclicamente de uma maneira extremamente eficiente e rápida, porém não é convencional saber a opinião do usuário sobre a automatização do ambiente. Em um ambiente com acessibilidade, isto é, uma prática comum antes, durante e depois do processo de automatização. É preciso conhecer as necessidades do usuário de maneira mais detalhada, visando atender com o máximo de eficiência as necessidades do utilizador. Para isso, conhecer as necessidades do usuário é essencial. A técnica do pré-teste e entrevista permite conhecer e catalogar as principais necessidades de um determinado grupo de usuários. No caso desse trabalho, o de UDV, não implicado que as mesmas técnicas possam ser utilizadas para catalogar as necessidades dos demais grupos com deficiência. 
Para esse projeto, por uma questão de custos, propõe-se a utilização de uma placa da plataforma do Arduino Mega 2560 que é baseada no micro controlador ATmega2560. Essa possui 54 (cinquenta e quatro) pinos de entradas e saídas digitais onde 15 (quinze) destes podem ser utilizados como saídas PWM. Será utilizado um módulo de Ethernet para Arduino. Depois que o projeto estiver pronto é de fundamental importância que os usuários possam fazer os testes para ajustar tanto a parte da interface quanto da domótica.

Depois do término dos testes e pré-testes é realizado o tratamento e análise dos dados coletados, questionários, observações e entrevistas, a fim de detectar as características mais comuns e dominantes da pesquisa. Essas características farão parte da criação das personas que auxiliarão na busca de uma interface acessível para o sistema.

\subsection{Definição do conceito de persona}

Alan Cooper em 1999 criou a técnica de persona que foi popularizada com seu livro: "The inmates are running the asylum: why high-tech products drive us crazy and how to restore the sanity" (COOPER, 1999). Segundo o autor, persona é um conjunto de informações que representam e caracterizam o usuário estudado. A partir de uma série de entrevistas com pessoas reais cria-se uma persona com uma descrição de um usuário arquetípico de características de um modelo ou padrão exemplar e sintetizado. A intenção é desenvolver um produto que venha a satisfazer as necessidades de muitos usuários.

O uso de persona pode ser usado com técnica de usabilidade, que consiste na criação de perfis e personificação de grupo de usuários, ou seja, representa uma caracterização de um personagem que, embora seja fictício, expõe as características mais importantes da população de usuários para a qual se destina o produto ou projeto (Adlin 2006). Tanto os aspectos sociais quanto os aspectos psicológicos dos usuários devem ser bem entendidos a fim de possibilitar o conhecimento das reais motivações que permeiam suas ações (Nielsen, 2002).

Tradicionalmente, usam-se técnicas de entrevistas, observação, verificação contextual, pré-teste e outros métodos qualitativos para a elaboração das personas. Com o objetivo de suplantar as dificuldades encontradas pela indústria de software no entendimento das reais necessidades de usuários distintos, o uso de personagens e representações concretas, conhecidas como personas, apresentam-se como uma interessante técnica de design (Grudin 
et al. 2002). Em geral, a técnica de personas é considerada bastante madura e consistente na representação e modelagem dos perfis de usuários de um sistema (Nóbrega 2011).

No contexto desse trabalho foram realizados pré-testes e observações como objeto de coleta de dados em um grupo de 20 (vinte) estudantes da Universidade de Brasília durante a disciplina de "Tópicos Especiais em Comunicação e Mediação de Informação: Design Centrado no Usuário da Informação" sob a supervisão da professora Ivette Kafure e com o consentimento dos alunos. A intenção era analisar a reação dos usuários, todos videntes, ao serem confrontados com os ambientes dos UDV. Dessa forma, pode-se criar um ambiente sem acessibilidade aos usuários observados (Seção 5 (cinco)). Assim, foi possível criar o modelo de persona: um usuário vidente que usará a interface do sistema de automação residencial sugerido pelos UDV.

\subsection{Tarefas $x$ Atividades}

Para coletar dados a fim de tornar o SAR mais acessível para o usuário, foi realizado o método de avaliação empírico, ou seja, aquele no qual se envolve usuários para a coleta de dados. No caso particular, foram feitos pré-testes com o auxilio de tarefas e atividades a fim de identificar os problemas mais comuns relacionados à acessibilidade de interface de dispositivos móveis. Os dados coletados posteriormente foram analisados e dessa forma foi criada a interface do aplicativo que controla a central.

"O design de IHC visa elaborar um modelo conceitual de entidades e atributos de domínio e do sistema, estruturar as tarefas e projetar a interação e a interface de um sistema interativo que apoie os objetivos do usuário.” (BARBOSA, 2010, p. 208). Nesse contexto, o conceito de tarefa refere-se ao que é esperado no âmbito de um processo de trabalho específico com suas singularidades locais. "Quando do comprimento e desenvolvimento de tarefas, essas pessoas deixam de ser um amontoado para tornarem-se um grupo, uma vez que têm um objetivo em comum" (FREIRE, 1992, p. 36). Trata-se das atividades realizadas para atingir uma meta vinculada às regras e objetivos fixados pela organização do trabalho. Nesse sentido, é possível identificar duas faces do trabalho: a tarefa (trabalho prescrito) e a atividade (trabalho real). Os levantamentos dos requisitos sobre as tarefas e os usuários, podem ser mais bem realizados quando os analistas procuram descrever situações do processo de trabalho. $\mathrm{O}$ objetivo da análise de tarefas é fornecer ao designer a visão dos usuários que eles precisam 
realizar. Segundo Card et al., (1983), a modelagem de tarefas consiste em formalizá-las de forma a mapeá-las na interface gráfica.

Adicionalmente, sistemas adaptáveis e adaptativos trazem grandes desafios para todas as atividades de IHC. A descrição das atividades e seus passos devem ser relacionados às metas a serem atingidas. Assim, as atividades múltiplas, tarefas com ocorrência prevista, possibilidades de antecipação, possibilidade de repartição de tempo entre diferentes tarefas dos operadores e as atividades interferentes devem ser estudadas. Um estudo semelhante deve ser feito para atividades com ocorrência imprevista, impossibilidade de antecipação, necessidade de diferentes modalidades de gestão e regulação temporal (Gadbois, 1991; Santos, 2002). A noção de atividade está ligada àquilo que realmente um operador executa em seu trabalho.

\subsection{Conclusões do capítulo}

Esse capítulo apresentou os principais estudos referentes à acessibilidade, à interface homem computador e à automação residencial com foco nos UDV total e parcial residentes no Brasil, especificamente no Distrito Federal.

Foram estudadas as principais terminologias utilizadas a respeito de deficiência visual à luz da legislação vigente. Assim como também foram tratados os principais conceitos e mecanismos de coleta de dados e os mais importantes protocolos do SAR.

Os pré-testes foram abordados como mecanismos eficientes para coletar e analisar dados com finalidade de criação da persona que auxiliasse no desenvolvimento da interface para o sistema domótico em questão. Neste caso, o estudo dos principais tipos de design foi abordado. Destacou-se o design emocional, que tem como foco a melhor metodologia para interface dentro da domótica organizadas de acordo com arquétipos representativos do perfil dos UDV, as personas. Durante os pré-testes, o design emocional dos usuários entrevistados também deve ser considerado.

Foram apresentados os parâmetros necessários para o cálculo do tamanho da amostra necessária na execução dos pré-testes com base nos dados do censo de 2010 do IBGE. Com isso, buscou-se um embasamento teórico suficiente para o desenvolvimento dos melhores métodos acessíveis aos deficientes visuais na automação residencial. 


\section{ASPECTOS METODOLÓGICOS E O PROJETO DA INTERFACE HOMEM COMPUTADOR}

\subsection{Análise e delimitação do espaço amostral a ser estudado}

Segundo dados do censo de 2010 datados pelo Instituto Brasileiro de Geografia e Estatística - IBGE ${ }^{7}$, no Brasil mais de 6,5 milhões de pessoas têm alguma deficiência visual. Do total referido, 528.624 de pessoas são incapazes de enxergar (cegos) e 6.056.654 possuem grande dificuldade permanente de enxergar (baixa visão ou visão subnormal). Mesmo que usando óculos ou lentes, 29 milhões de pessoas declararam possuir alguma dificuldade permanente de enxergar.

Foi escolhido o Distrito Federal como escopo amostral de pesquisa pela inviabilidade de ampliar esse projeto de modo a abranger todo o Brasil, levando-se em consideração a limitação do tempo e dinheiro. Em Brasília a população em 2010 era de 2.570 .160 habitantes, como mostrado na figura 3-1. Do total referido, 388890 não enxergam de modo algum, 68047 tem grande dificuldade de enxergar e 6436 tem alguma dificuldade visual. Esses dados podem ser conferidos na figura 3-2.

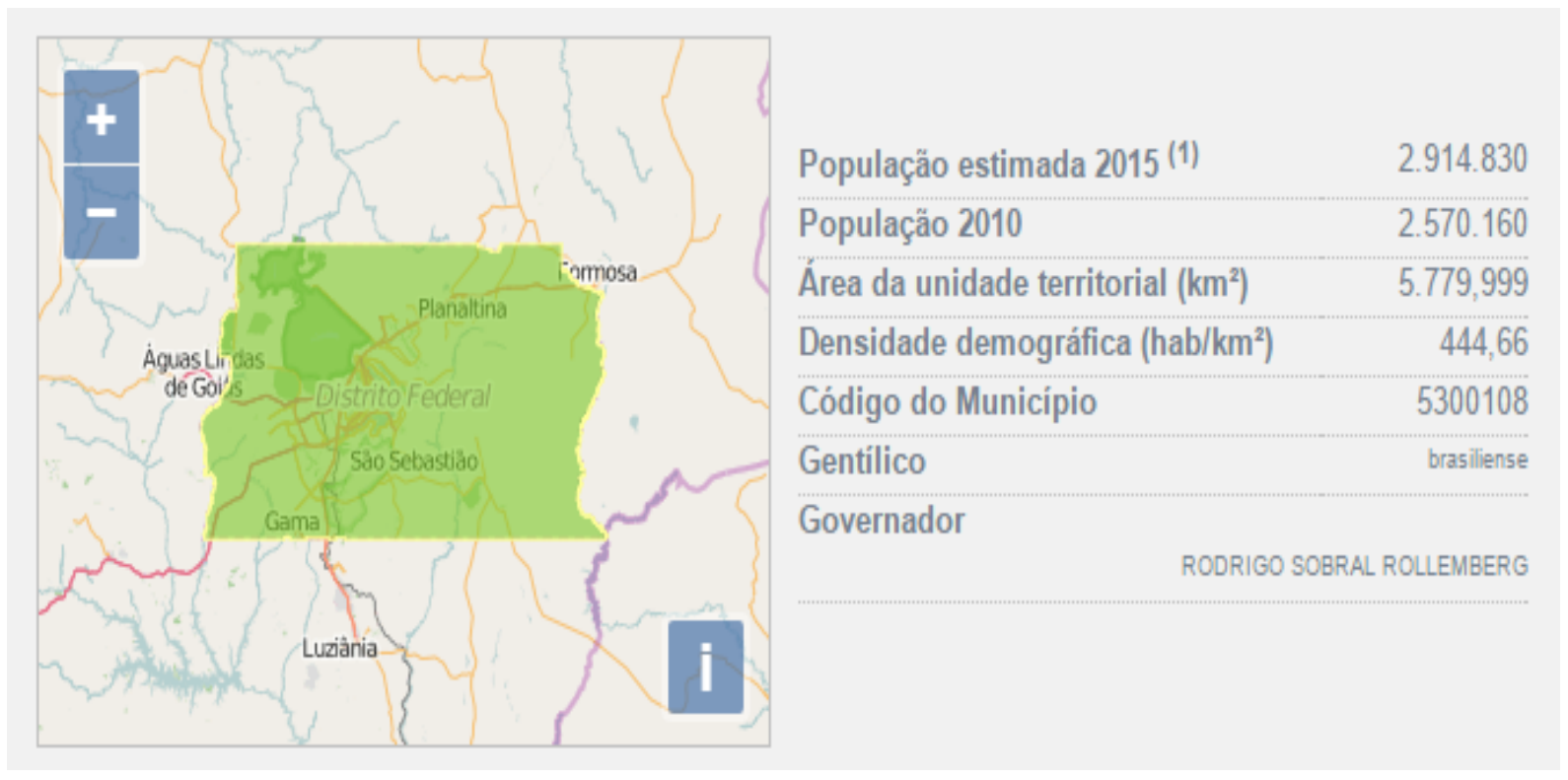

Figura 3-1- Informações Estatísticas (FONTE: IBGE)

${ }^{7}$ http://www.ibge.gov.br/ 
População residente, por tipo de deficiência permanente

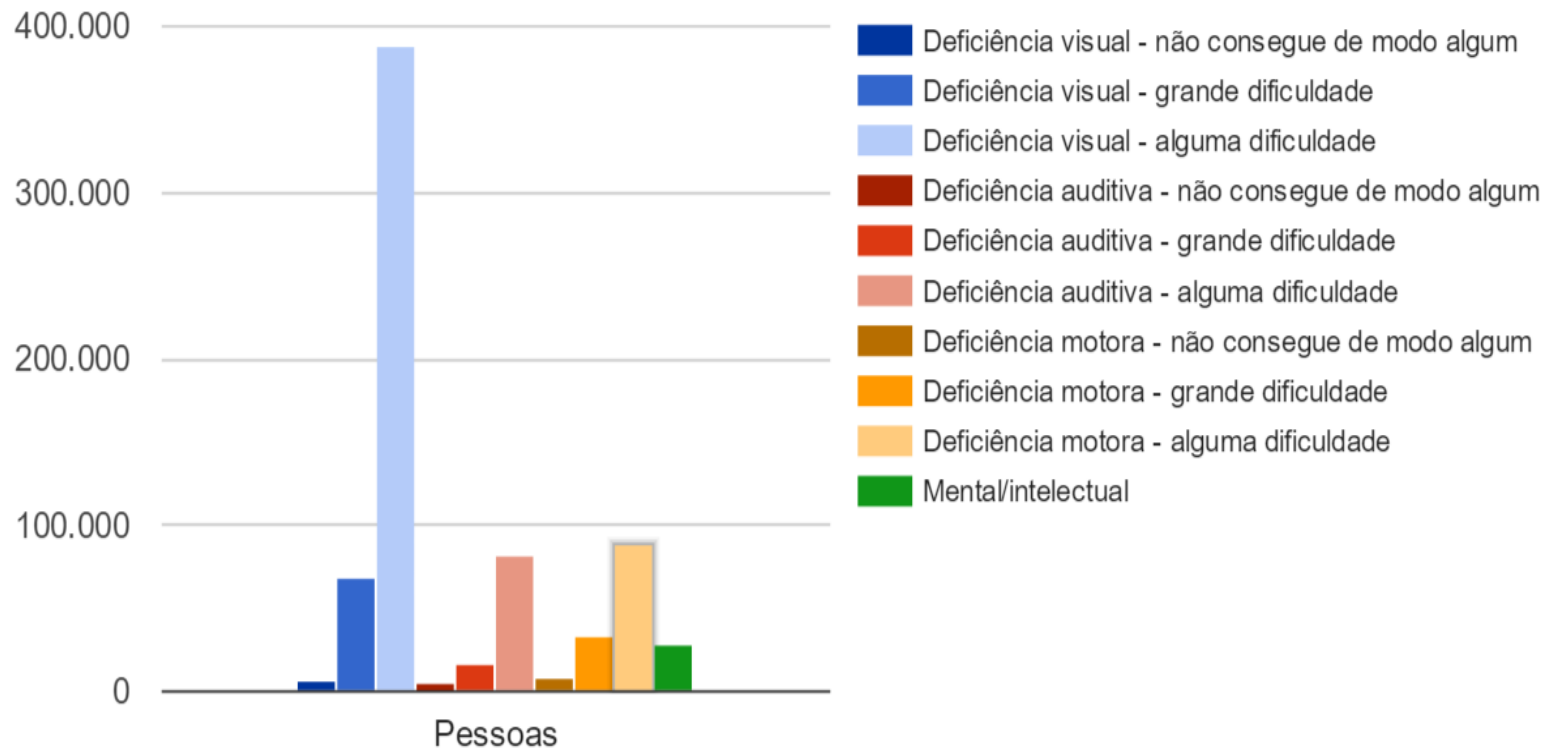

Figura 3-2 - Gráfico dos Diferentes Graus de Deficiência Visual (FONTE: CENSO 2010 ${ }^{8}$ ).

A Tabela 3-1 mostra as características financeiras dos deficientes visuais divididas em faixas salariais e grau de deficiência. Assim, sabe-se que 52,79\% dos usuários tem renda entre um e dois salários mínimos. Sendo assim, a fim de atender a todas as faixas salariais, a central de automação não poderia ter custo elevado para que todos pudessem adquiri-la. Neste sentido, o valor de um protótipo acessível financeiramente foi orçado em $\mathrm{R} \$ 257,8$.

Tabela 3-1 - Tabela relacional: Grau de deficiência X Renda

\begin{tabular}{|c|c|c|c|}
\hline $\begin{array}{l}\text { Característica: } \\
\text { Salário mínimo }\end{array}$ & $\begin{array}{l}\text { Não consegue } \\
\text { de modo algum }\end{array}$ & $\begin{array}{l}\text { Grande } \\
\text { dificuldade }\end{array}$ & $\begin{array}{l}\text { Alguma } \\
\text { dificuldade }\end{array}$ \\
\hline \multicolumn{4}{|l|}{10 anos ou +} \\
\hline Até $1 / 2$. & 103 & 1.973 & 6.546 \\
\hline+ de $1 / 2$ a 1 & 539 & 8.118 & 39.871 \\
\hline$+\mathrm{de} 1 \mathrm{a} 2$ & 1.034 & 9.706 & 64.759 \\
\hline$+\mathrm{de} 2$ a 3 & 269 & 3.111 & 22.349 \\
\hline$+\mathrm{d}$ e 3 a 5 & 283 & 3.002 & 21.091 \\
\hline$+\mathrm{d}$ e 5 a 10 & 534 & 2.804 & 30.381 \\
\hline$+\mathrm{d}$ e 10 a 15 & 213 & 798 & 9.098 \\
\hline$+\mathrm{d}$ e 15 a 20 & 47 & 484 & 7.871 \\
\hline$+\mathrm{d}$ e 20 a 30 & 36 & 570 & 5.276 \\
\hline$+\mathrm{d}$ e 30 & 45 & 267 & 3.359 \\
\hline Sem rendimento & 0 & 1.203 & 5.544 \\
\hline
\end{tabular}

\footnotetext{
${ }^{8}$ http://www.censo2010.ibge.gov.br/apps/mapa/
} 


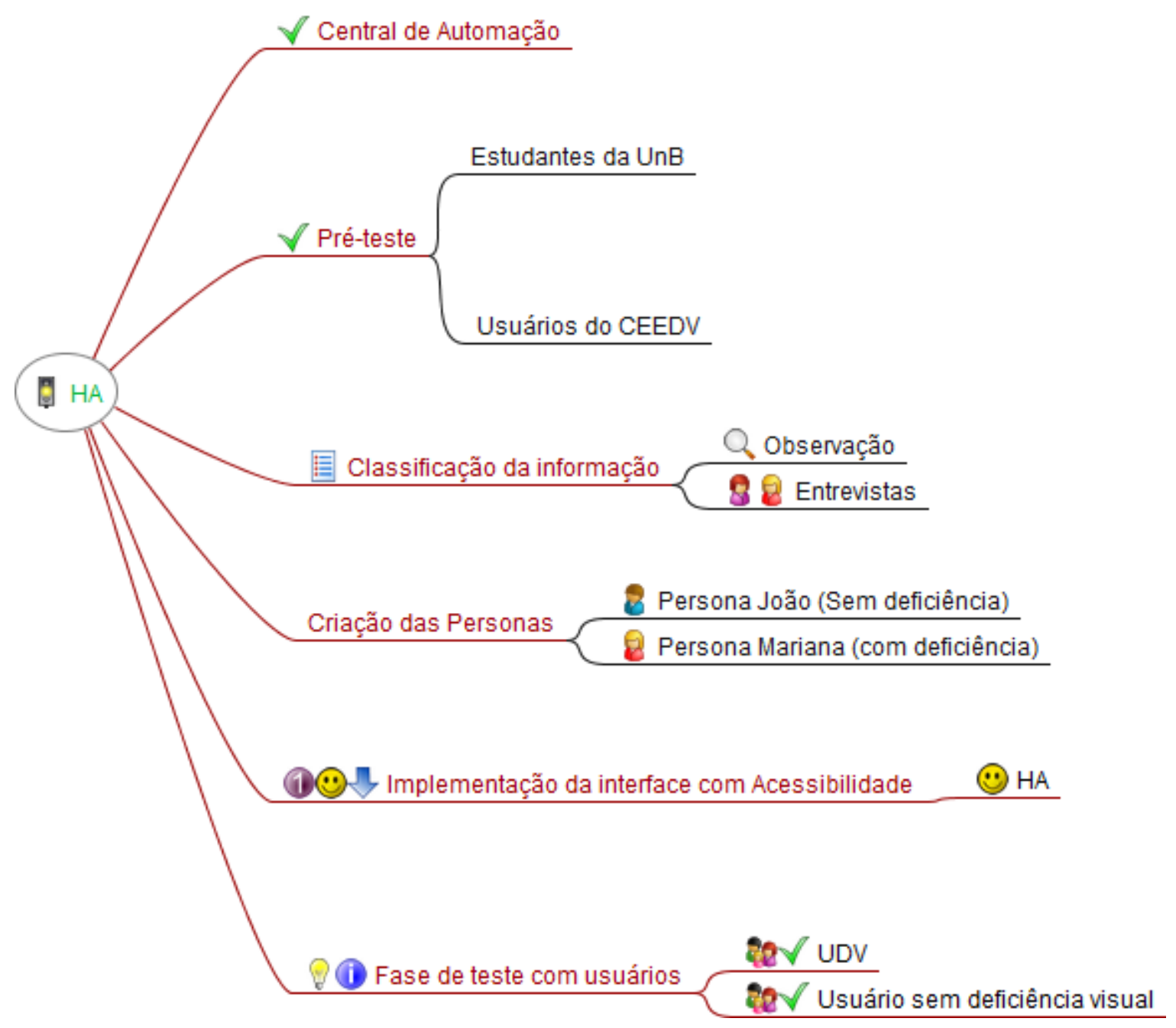

Fluxograma 3-1 - Atividades a realizar

Com a central de automação já definida, segundo o Fluxograma 3-1, tem início a fase dos pré-testes. Essa fase começou nas dependências da Universidade de Brasília com os alunos da disciplina de Tópicos Especiais em Comunicação e Mediação de Informação: Design Centrado no Usuário da Informação sob a supervisão da Professora Ivette Kafure. Foi realizado um pré-teste no qual os alunos tiveram de simular as dificuldades de um usuário que passou por um trauma recentemente e perdeu um dos seus sentidos visual ou auditivo ou motor, para criar uma interface que pudesse atender a todos os utilizadores, deficientes visuais ou não.

Dessa forma, foi possível conhecer as principais dificuldades de um usuário, que necessita conviver com uma deficiência permanente, e assim, analisar suas emoções ao conhecer uma aplicação com e sem acessibilidade pela primeira vez. Nesse caso, o tamanho da amostra foi de 20 usuários, $100 \%$ do espaço amostral, porém, para fins dessa pesquisa e para que essa tivesse mais confiabilidade, foi preciso realizar pré-testes dedicados ao público 
específico, UDV, a fim de detectar os problemas recorrentes referentes à falta de acessibilidade das páginas WEB e de aplicativos.

Dando prosseguimento à fase dos pré-testes houve o cálculo do tamanho da amostra necessária para realizá-los com os usuários deficientes visuais, tendo em vista que por questão de logística e tempo não seria possível entrevistar todos os 251284 deficientes do Distrito Federal.

\subsubsection{Cálculo do tamanho da amostra}

A partir dos dados do IBGE referentes à quantidade de pessoas com alguma deficiência visual residentes no Distrito Federal, seria possível calcular a amostra, o nível de confiança e o erro amostral necessário para a realização da pesquisa. Porém, como a pesquisa envolvia a participação de se seres humanos, foi preciso que antes o projeto fosse aprovado pelo Comitê de Ética da Medicina da Universidade de Brasília e ter prosseguimento.

Em razão da população com deficiência visual do Distrito Federal ter um número considerável de pessoas, foi realizada uma consulta aos maiores aglutinadores de deficientes visuais para ter ciência da média de usuários que poderiam se voluntariar, dentro dos parâmetros do Termo de Consentimento Livre e Esclarecido - TCLE, a realizarem o pré-teste. Mesmo assim, não alcançaram um número de voluntários suficientes para a realização da pesquisa capaz de gerar o nível de confiança de $95 \%$.

Foi realizada uma visita ao Programa de Apoio às Pessoas com Necessidades Especiais/UnB - PPNE da Universidade de Brasília, onde são atendidos 11 alunos deficientes visuais estudantes de todos os campos da universidade. Esses foram convidados pelo próprio PPNE por e-mail. Entretanto, não houve adesão para participar da pesquisa.

Posteriormente, foi feito contato com a Associação Brasiliense de Deficientes Visuais - $A B D V$, entidade representativa das PDV do DF, que nos encaminhou para o Centro de Ensino Especial de deficientes Visuais CEEDV.

Dessa maneira, foi possível realizar uma visita de campo no CEEDV a fim de conversar e convidar voluntários para participar dos pré-testes. Entretanto, não houve grande adesão dos usuários. Todos sabem da importância dessas pesquisas, porém a maioria não quis participar dos pré-testes alegando não saber manusear devidamente o computador ou o 
celular. Também alegaram ter vergonha de errar e medo de não conseguir realizar toda a atividade. Em respeito à individualidade de cada voluntário, esse e outros motivos ocasionaram uma redução no escopo de possibilidades de usuários. Dos utilizadores do CEEDV 21 (vinte e uma) pessoas se voluntariaram a realizar o teste.

Após a concessão da permissão para os experimentos por parte do comitê de Ética de Medicina da Universidade de Brasília e do CEEDV, foram realizados os pré-testes com os UDV totais e parciais. O tempo que foi acordado, para a realização da pesquisa com o centro de ensino, foi de sessenta (60) dias corridos. Nesse período, os usuários que aceitaram participar realizaram os pré-testes de acordo com suas disponibilidades de dia e horário.

Tendo com base a quantidade de pessoas que realizaram os pré-testes, foi realizado o cálculo do nível de confiança, com um erro amostral de $18 \%$. Para este calculo foi utilizada a equação ( II ) obtendo os seguintes valores:

- UDV no Distrito Federal - 251284;

- Amostra pesquisada- 21 usuários;

- Nível de confiança atingido $90 \%$ - Z=1,645;

- Erro amostral-18\%.

\subsubsection{Aplicação da técnica de pré-teste}

Para o primeiro grupo (alunos da UnB) foram aplicados pré-testes baseados em três cenários. A

Tabela 3-2 define os cenários nos quais os participantes puderam ser observados ao simular dificuldades quando um sentido sensorial (visual ou auditivo) ou motor está privado.

Tabela 3-2 Definição dos cenários

\begin{tabular}{|l|l|c|}
\hline Primeiro Cenário & Segundo cenário & Terceiro cenário \\
\hline Deficiência Visual & Deficiência Auditiva & Deficiência Motora. \\
- Total & $\bullet$ Total & • Perda da mobilidade das mãos \\
- Parcial & & e pernas. \\
\hline \multicolumn{2}{|l|}{} & \multicolumn{1}{|l}{} \\
\cline { 1 - 2 }
\end{tabular}

A seguir foi solicitado aos alunos realizarem as seguintes atividades:

1) Escolher um cenário definido.

2) Realizar as tarefas referentes ao cenário. 
3) Fazer as considerações a respeito do pré-teste.

Para a realização dos pré-testes em todos os cenários, foi sugerida uma matéria jornalística de um grande sítio nacional de notícias. O detalhamento de como proceder em cada cenário foi dividido em tarefas, tal como descrito na Tabela 3-3. Para o bom andamento da pesquisa foi necessário que todos os alunos realizassem os pré-testes durante os 90min de aula, supervisionadas pela professora Ivette Kafure. Durante o experimento, o gerenciador do pré-teste fazia anotações a fim de confrontar com as considerações dos alunos. Os alunos não puderam ser ajudados durante o pré-teste, levando-se em consideração que todas as informações foram disponibilizadas antes da execução do experimento.

A intenção era avaliar as dificuldades, reações, sentimentos que uma pessoa recémtraumatizada enfrenta ao acessar um sítio por meio de um dispositivo móvel ou computador.

Tabela 3-3 - Métodos e Tarefas de cada cenário a serem realizados nos Pré-testes.

\begin{tabular}{|c|c|c|}
\hline Cenário & Método & Tarefa \\
\hline Primeiro cenário & $\begin{array}{l}\text { Uso dos monitores com o vídeo } \\
\text { desabilitado ou o uso de vendas nos } \\
\text { olhos dos participantes. } \\
\text { FINALIDADE - Simular } \\
\text { ambiente de deficiente visual total. } \\
\text { Utilização da página Web no } \\
\text { modo de acessibilidade, utilizando } \\
\text { contraste e mudança do tamanho da } \\
\text { fonte. } \\
\text { FINALIDADE - Simular } \\
\text { ambiente de deficiente visual } \\
\text { parcial. } \\
\text { Uso apenas do teclado. } \\
\text { mouse não pôde ser utilizado. } \\
\text { FINALIDADE - Deficientes } \\
\text { visuais utilizam teclas de atalho } \\
\text { para realizar tarefas } \\
\text { computador. no } \\
\text { Uso do programa NVDA, } \\
\text { software gratuito utilizado para } \\
\text { leitura de tela de computador. } \\
\text { FINALIDADE - Software de } \\
\text { leitor de tela gratuito, acessível e } \\
\text { compatível com o Windows. } \\
\text { Uso de fones de ouvido. } \\
\text { FINALIDADE - }\end{array}$ & $\begin{array}{l}\text { Simulação de deficiente } \\
\text { total: } \\
\text { Utilização do browser, } \\
\text { de preferência do aluno, } \\
\text { para entrar no sítio de } \\
\text { notícia requerido pelo } \\
\text { gerenciador do pré-teste e } \\
\text { com o auxilio do NVDA, } \\
\text { previamente instalado, } \\
\text { relatar uma notícia que } \\
\text { esteja na primeira página } \\
\text { do referido sítio. } \\
\text { Com o auxílio de o } \\
\text { teclado mudar pelo menu } \\
\text { de opção da primeira } \\
\text { página ou aba para uma } \\
\text { outra sugerida pelo } \\
\text { gerenciador do pré-teste. }\end{array}$ \\
\hline
\end{tabular}




\begin{tabular}{|c|c|c|}
\hline & & $\begin{array}{l}\text { Simulação de deficiente } \\
\text { parcial: } \\
\text { 1. Utilização do browser, } \\
\text { de preferência do } \\
\text { aluno, para entrar no } \\
\text { sítio de notícia } \\
\text { requerido pelo } \\
\text { gerenciador do pré- } \\
\text { teste e colocar no modo } \\
\text { de acessibilidade da } \\
\text { página. } \\
\text { 2. Modificar o tamanho da } \\
\text { fonte da página e } \\
\text { verificar se a qualidade } \\
\text { ainda continua } \\
\text { suficiente para leitura. } \\
\end{array}$ \\
\hline Segundo cenário & $\begin{array}{l}\text { - Uso de computadores com as } \\
\text { caixas de som desligadas. } \\
\text { FINALIDADE - simulando } \\
\text { usuários que não poderiam ouvir } \\
\text { os sons de alerta, vídeos, games, } \\
\text { entre outros. }\end{array}$ & $\begin{array}{l}\text { 1. Utilização do browser, } \\
\text { de preferência do } \\
\text { aluno, para entrar no } \\
\text { sítio de notícia } \\
\text { requerido } \text { pelo } \\
\text { gerenciador do pré- } \\
\text { teste. Verificar se a } \\
\text { página possui os } \\
\text { módulos de } \\
\text { acessibilidade } \\
\text { sugeridos pelo W3C. } \\
\text { Entrar na aba de vídeos, } \\
\text { verificar se possuem } \\
\text { legendas. Descrever o } \\
\text { vídeo. } \\
\text { 2. Ler a notícia que } \\
\text { acompanha o vídeo, } \\
\text { verificar se a notícia é } \\
\text { fidedigna ao texto. }\end{array}$ \\
\hline Terceiro cenário & $\begin{array}{l}\text { - Uso apenas do teclado. O } \\
\text { mouse não pôde ser utilizado. } \\
\text { FINALIDADE - Usuários com } \\
\text { deficiências motoras podem } \\
\text { possuir mobilidade reduzida nas } \\
\text { mãos dificultando o uso do } \\
\text { mouse. }\end{array}$ & $\begin{array}{l}\text { 1. Utilização do browser, } \\
\text { de preferência do } \\
\text { aluno, para entrar no } \\
\text { sítio de notícia } \\
\text { requerido } \\
\text { gerenciador do pelo } \\
\text { teste. Verificar se a } \\
\text { página possui o módulo } \\
\text { de acessibilidade } \\
\text { sugerido pelo W3C. } \\
\text { Com o uso do teclado, }\end{array}$ \\
\hline
\end{tabular}




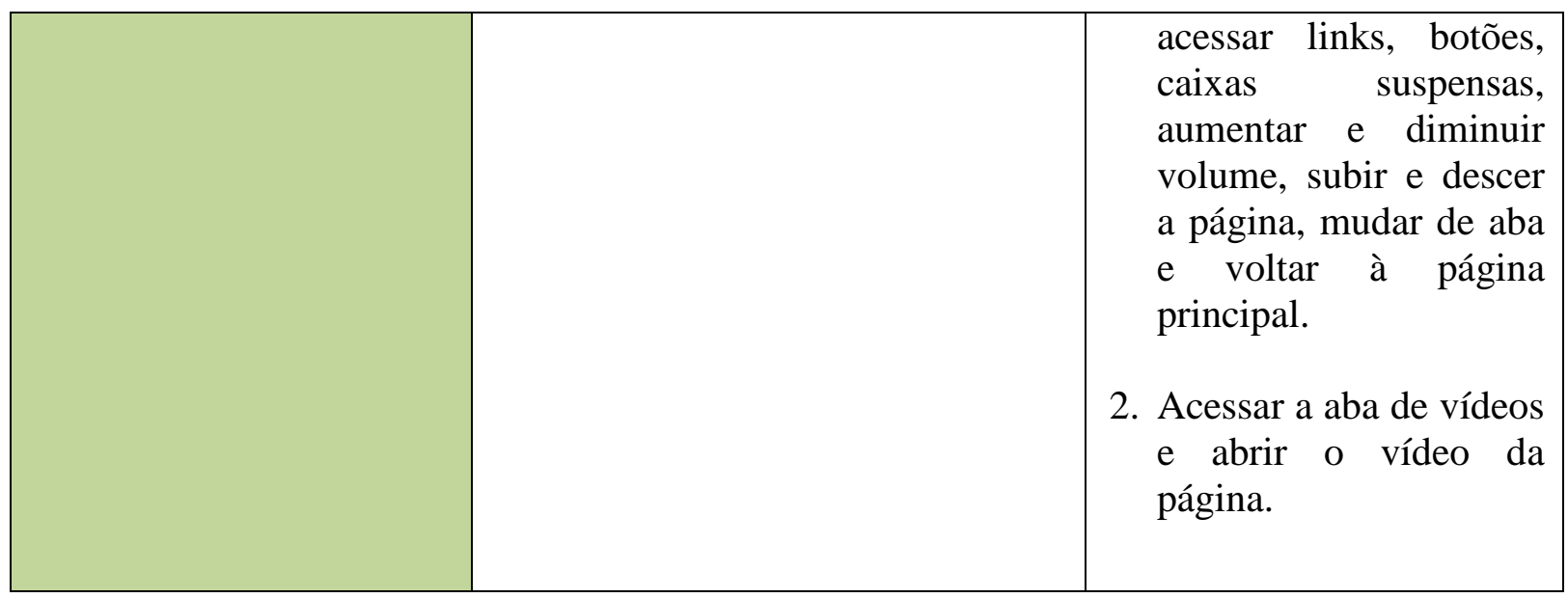

Os pré-testes do segundo grupo (PDV) foram realizados no CEEDV e para isso foi necessário que o centro de ensino disponibilizasse o local devidamente formalizado pelo Termo da Instituição Coparticipante.

Após a formalização do projeto e do local da pesquisa, foi necessário que os usuários voluntários atendessem a alguns requisitos: (a) Fossem maiores de dezoito (18) anos, (b) alfabetizados em série igual ou maior que a quarta $\left(4^{a}\right)$ série do ensino fundamental, (c) que soubessem escrever o nome por extenso devido às questões legais, (d) que soubessem abrir uma página $\mathrm{WEB}$, (e) que soubessem escrever um pequeno texto em um documento de texto e (f) que soubessem utilizar celulares com sistema operacional Android.

Para ser validado o pré-teste do usuário, esse deveria estar de acordo com o TCLE. O teste foi dividido em dois grupos: (a) usuários que fizeram o pré-teste utilizando o celular e (b) usuários que fizeram o pré-teste utilizando o computador.

A duração do pré-teste, com o questionário (Apêndice B) e a entrevista, na qual o usuário respondeu às perguntas presentes nos três instrumentos de pesquisa, teve duração média de uma hora. $\mathrm{O}$ usuário teve seu direito garantido de poder se retirar a qualquer momento, sem nenhum tipo de prejuízo ou retaliação pela sua decisão. As fases do pré-teste estão dispostas na Tabela 3-4. 
Tabela 3-4 - Etapas dos Pré-testes com os usuários deficientes visuais.

\begin{tabular}{|c|c|}
\hline Primeira etapa do pré-teste & Segunda etapa do pré-teste \\
\hline 1. Convidar os usuários para realizar o pré-teste. & $\begin{array}{l}\text { 1. Entrar no sítio: } \\
\qquad<\text { http://g1.globo.com> }\end{array}$ \\
\hline 2. Apresentação pessoal da pesquisadora. & $\begin{array}{l}\text { 2. Tempo de navegação no sítio de } 10 \\
\text { min para conhecer a estrutura }\end{array}$ \\
\hline 3. Apresentação dos usuários- individual. & $\begin{array}{l}\text { 3. Encontrar o item requisitado. } \\
\text { Matéria da } 1^{\circ} \text { página (Matéria } \\
\text { sugerida pela pesquisadora) }\end{array}$ \\
\hline 4. Apresentação da proposta do trabalho. & $\begin{array}{l}\text { 4. Encontrar o conteúdo multimídia } \\
\text { sugerido. }\end{array}$ \\
\hline $\begin{array}{l}\text { 5. Início do Pré-teste explicando como será } \\
\text { realizado. Passo-a-passo. }\end{array}$ & $\begin{array}{l}\text { 5. Pelo ícone de buscar do sítio, } \\
\text { encontrar a segunda matéria } \\
\text { sugerida. Matéria disposta em } \\
\text { páginas secundárias. }\end{array}$ \\
\hline
\end{tabular}

A escolha do sítio utilizado foi baseada no volume e na variedade de informação que o mesmo proporciona ao consumidor dessas informações. Outros fatores que foram considerados: (a) o sítio tem um aplicativo para celular que torna a navegação mais fácil para o deficiente visual, porém o usuário foi convidado a utilizar o navegador tanto no computador quanto no celular. Com isso, houve a intenção de extrair as maiores dificuldades de cada usuário em um ambiente sem acessibilidade, (b) a falta de acessibilidade do sítio tanto para deficientes visuais totais quanto parciais. Não há o comprimento das diretrizes do W3C, (c) a intenção de extrair do usuário suas dificuldades, suas facilidades e suas reações, (d) submeter o usuário ao ambiente sem acessibilidade leva-lo a procurar soluções para os problemas que ele enfrentou.

Foi definido um tempo máximo de 10 min de navegação (antes da execução do préteste) a fim do usuário (a) se ambientar com o computador, (b) conhecer as particularidades do NVDA, (c) ter uma noção de onde encontrar o navegador na área de trabalho e (d) ter noção básica da estrutura do sítio, tabular no caso. Considerando-se essas ideias, não foi oferecido tempo adicional tendo em conta que o pré-teste visa simular uma situação de adversidade sendo que todas as dificuldades dadas são importantes para avaliar os resultados do experimento. 
O detalhamento de como proceder em cada cenário foi dividido em tarefas descritas na Tabela 3-5. Os usuários puderam escolher se preferiam realizar o pré-teste coletivamente ou individualmente. Ao final do pré-teste, o usuário era convidado a responder um questionário com algumas perguntas referentes ao teste e sobre o seu sentimento ao realizá-lo. Buscou-se assim entender o design visceral do usuário. Logo depois o usuário pôde dar sugestões de melhoria da página ou como aperfeiçoar um aplicativo de sua preferência.

Tabela 3-5 Descrição dos cenários e das tarefas que serão realizadas nos pré-testes com deficientes visuais.

\begin{tabular}{|c|c|}
\hline Cenário & Ta \\
\hline $\begin{array}{l}\text { Deficiente visual } \\
\text { Parcial } \\
\text { Uso de Computador }\end{array}$ & $\begin{array}{l}\text { 1. Utilização do browser, de preferência do aluno, para } \\
\text { entrar no sítio de notícia requerido pela pesquisadora. } \\
\text { 2. Acessar o módulo de acessibilidade da página. } \\
\text { 3. Verificar se a notícia lida na primeira página foi bem } \\
\text { compreendida. } \\
\text { 4. Acessar o vídeo na aba de vídeos, verificar se existe a } \\
\text { opção de legenda, em caso afirmativo, verificar se há } \\
\text { opção de mudança do tamanho da fonte. } \\
\text { 5. Verificar se os links e propagandas tinham problemas. } \\
\text { 6. Encontrar uma matéria específica requerida pela } \\
\text { pesquisadora utilizando o buscador do sítio. }\end{array}$ \\
\hline $\begin{array}{l}\text { Deficiente visual } \\
\text { Parcial } \\
\text { Uso de Celular com } \\
\text { sistema operacional } \\
\text { Android }\end{array}$ & $\begin{array}{l}\text { 1. Uso das funções de acessibilidade do celular para acessar } \\
\text { o sítio sugerido. } \\
\text { 2. Acessar a notícia da primeira página. } \\
\text { 3. Verificar se a página aumenta com um toque no celular } \\
\text { ou se possui acessibilidade na própria casa. } \\
\text { 4. Acessar o vídeo na aba de vídeos, verificar se existe a } \\
\text { opção de legenda, em caso positivo, verificar se há opção de } \\
\text { mudança no tamanho da fonte. } \\
\text { 5. Verificar os links e propagandas tinham problemas. } \\
\text { 6. Encontrar uma matéria específica requerida pela } \\
\text { pesquisadora utilizando o buscador do sítio. }\end{array}$ \\
\hline
\end{tabular}




\begin{tabular}{|c|c|}
\hline $\begin{array}{l}\text { Deficiente visual Total } \\
\text { Uso de Computador }\end{array}$ & $\begin{array}{l}\text { 1. Utilização do browser, de preferência do aluno, para } \\
\text { entrar no sítio de notícia requerido pela pesquisadora. } \\
\text { 2. Verificar a notícia da primeira página utilizando o } \\
\text { software de leitura de texto NVDA. } \\
\text { 3. Verificar se na página existe a opção de acessibilidade e } \\
\text { de leitura de gráficos, imagens e ícones que obedeçam às } \\
\text { diretrizes da W3C. } \\
\text { 4. Com os mecanismos de acessibilidade do sítio, assistir ao } \\
\text { vídeo e verificar se a notícia sugerida sendo lida ou } \\
\text { ouvida coincidem e se há alguma diferença notada pelo } \\
\text { usuário. } \\
\text { E. Encontrar o ícone de busca do sítio e acessar a segunda } \\
\text { notícia sugerida. } \\
\text { 6. Verificar se houve problema com os links e as } \\
\text { propagandas. }\end{array}$ \\
\hline $\begin{array}{l}\text { Deficiente visual Total } \\
\text { Uso de Celular com } \\
\text { sistema operacional } \\
\text { Android }\end{array}$ & $\begin{array}{l}\text { 1. Uso das funções de acessibilidade do celular para acessar } \\
\text { o sítio sugerido. } \\
\text { 2. Acessar a notícia da primeira página por meio do } \\
\text { talkback do celular. } \\
\text { 3. Verificar se na página existe a opção de acessibilidade e } \\
\text { de leitura de gráficos, imagens e ícones que obedecem às } \\
\text { diretrizes da W3C. } \\
\text { 4. Com os mecanismos de acessibilidade do sítio, assistir ao } \\
\text { vídeo e verificar se a notícia sugerida sendo ouvida ou } \\
\text { lida coincidem e se há alguma diferença notada pelo } \\
\text { usuário. } \\
\text { 5. Encontrar o ícone de busca do sítio e acessar a segunda } \\
\text { notícia sugerida. } \\
\text { 6. Verificar se houve problema com os links e as } \\
\text { propagandas. }\end{array}$ \\
\hline
\end{tabular}

Após a coleta dos dados observados durante os pré-testes, foi possível tratá-los e registrá-los em planilhas, para que os pontos em comum entre todas as respostas pudessem 
compor personas com características similares. A classificação dessas informações serviu de base para a criação de duas personas, uma com características dos alunos da UnB e a outra dos usuários do CEEDV como pode ser visualizada no Fluxograma 3-1.

\subsubsection{Criação das personas}

A criação das personas foi baseada nas características mais comuns tanto dos usuários insatisfeitos como dos usuários satisfeitos. Essas respostas foram dispostas em formas de gráficos e tabelas para facilitar as análises. As respostas subjetivas também foram consideradas, avaliadas e dispostas nos mesmos mecanismos. Dessa forma, foi possível criar uma persona chamada João da Silva, baseado na coleta dos dados do pré-teste dos alunos da UnB e outra Mariana Cordeiro, baseado na coleta dos dados dos usuários do CEEDV. Nesse caso, cada persona é capaz de responder às seguintes perguntas:

1) Qual foi o real problema de falta de acessibilidade que o usuário identificou?

2) Qual ou quais foram os trajetos que o usuário percorreu até conseguir realizar a tarefa?

3) Como o usuário se sentiu a respeito do pré-teste realizado?

4) Qual é a decisão por utilizar ou não uma interface do modelo proposto para o teste?

Após a criação das personas, foi possível implementar uma interface gráfica que atendesse os principais requisitos solicitados durante os pré-testes, facilitando o aprendizado do aplicativo e diminuindo o tempo gasto para realização das ações desejadas.

\subsubsection{Desenvolvimento da interface gráfica}

Para que a interface estivesse acessível aos UDV, obedecendo às diretrizes da W3C, e que os demais usuários também pudessem utilizar a mesma interface, sem gerar nenhum desconforto, foram desenvolvidos módulos de acessibilidade que pudessem ser acionados de acordo com a necessidade do usuário. Esses módulos compõem mecanismos de resposta tais como: vibrar a uma determinada ação, ter um bip sonoro, comando por voz (...), entre outros. A criação das personas, Mariana Cordeiro e João da Silva, permitiu o estabelecimento do melhor modelo de automação residencial com acessibilidade por meio de interface em um aplicativo para dispositivo móvel a um preço acessível. 
Primeiramente, foram elaborados esboços utilizando as diretrizes do $\mathrm{W} 3 \mathrm{C}$ que visam atender às personas criadas após realização dos pré-testes. Esses esboços podem ser vistos nas figura 3-3, 3-4 e 3-5.

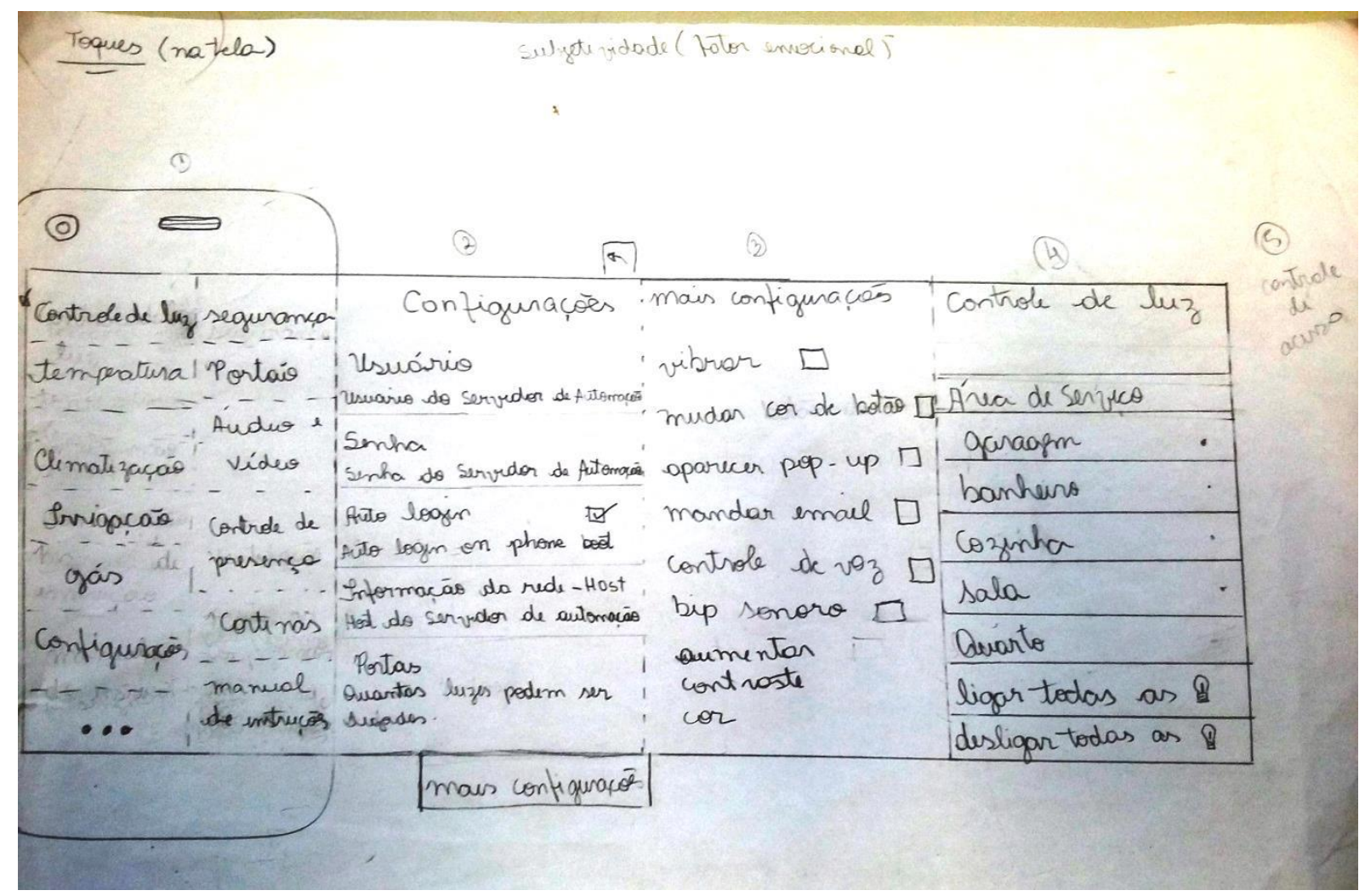

Figura 3-3 - Primeiro esboço

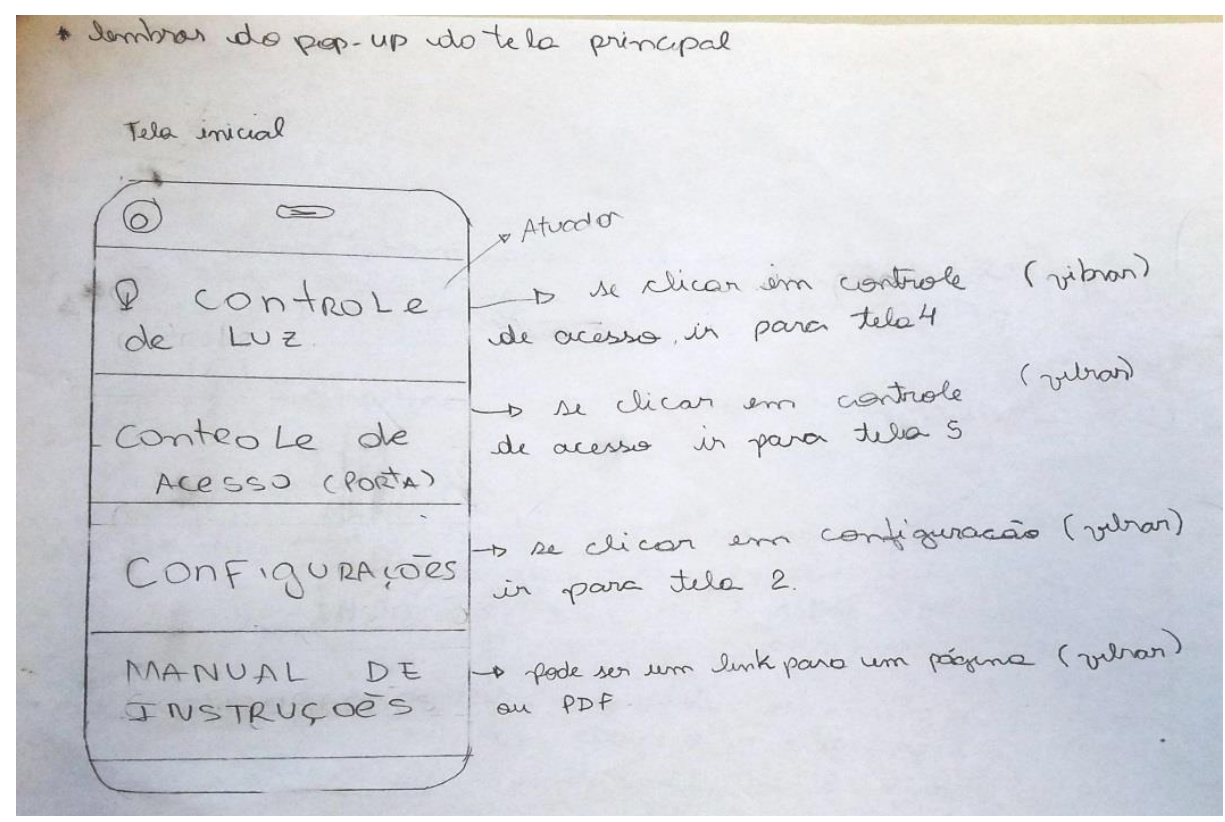

Figura 3-4 - Tela inicial - Segundo Esboço 


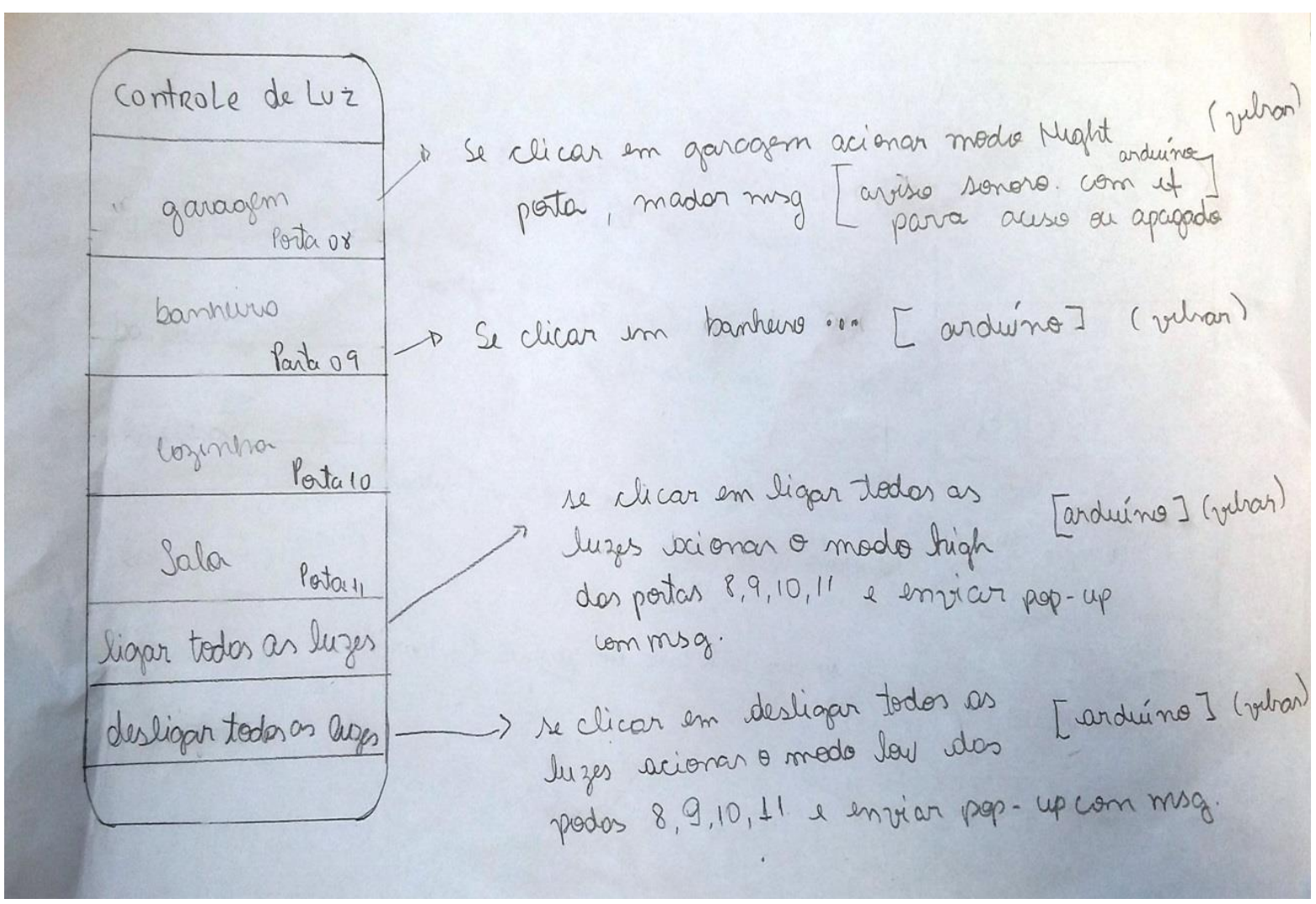

Figura 3-5 - Esboço do controle de luzes

Posteriormente, esses esboços serviram como base para implementar o protótipo da interface utilizando a ferramenta de criação de protótipos Justinmind ${ }^{9}$. A versão utilizada foi gratuita por 30 dias, que oferece recursos de prototipagem de interface de forma fácil, por meio de ferramentas de diagramação conforme as Figura 3-6,Figura 3-7, Figura 3-8,Figura 3-9 e Figura 3-10. Essa ferramenta possibilitou iniciar o desenvolvimento da criação da interface, pois a mesma possibilita simular o aplicativo criado em qualquer browser, fato que permite ao desenvolvedor ter uma noção de como ficou a interface do aplicativo e poder assim, fazer os devidos ajustes. Dessa maneira, teve-se a intenção de desenvolver uma interface que atenda aos quesitos de acessibilidade sugeridos durante os pré-testes.

\footnotetext{
${ }^{9}$ http://www.justinmind.com/
} 


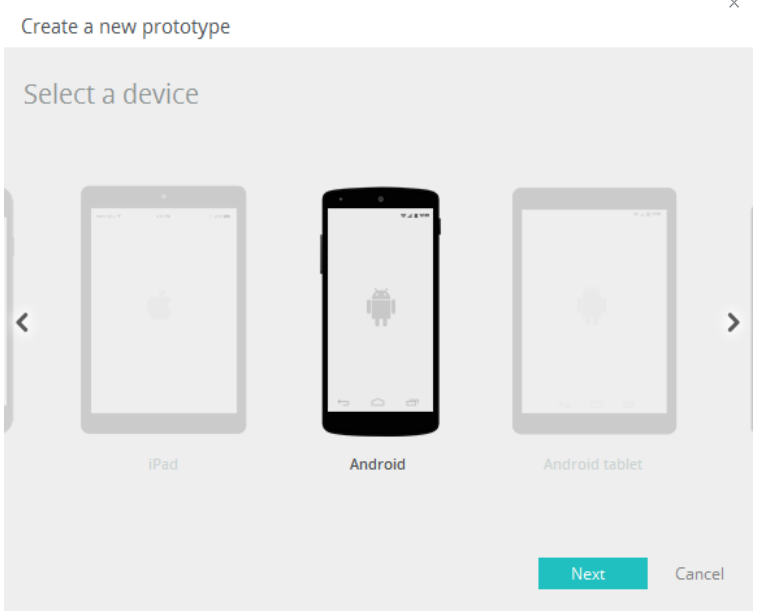

Figura 3-6 - Ferramenta de simulação de interface - JUSTINMIND. Escolha do protótipo, dispositivo móvel e Sistema Operacional.
Create a new prototype

Start your prototype from

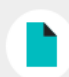

Empty

Define your prototype settings

- Predefined: $360 \times 640$

Custom: Width (px):

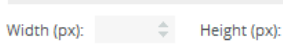

Figura 3-7 - Escolha das configurações básicas de forma.

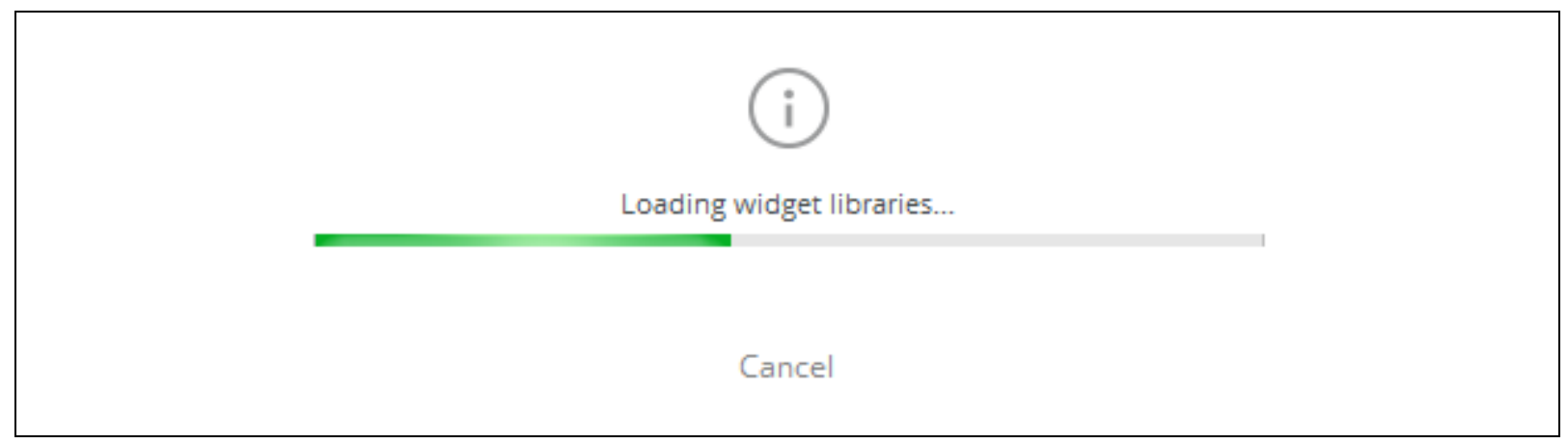

Figura 3-8 - Processando as bibliotecas necessárias para a criação do protótipo

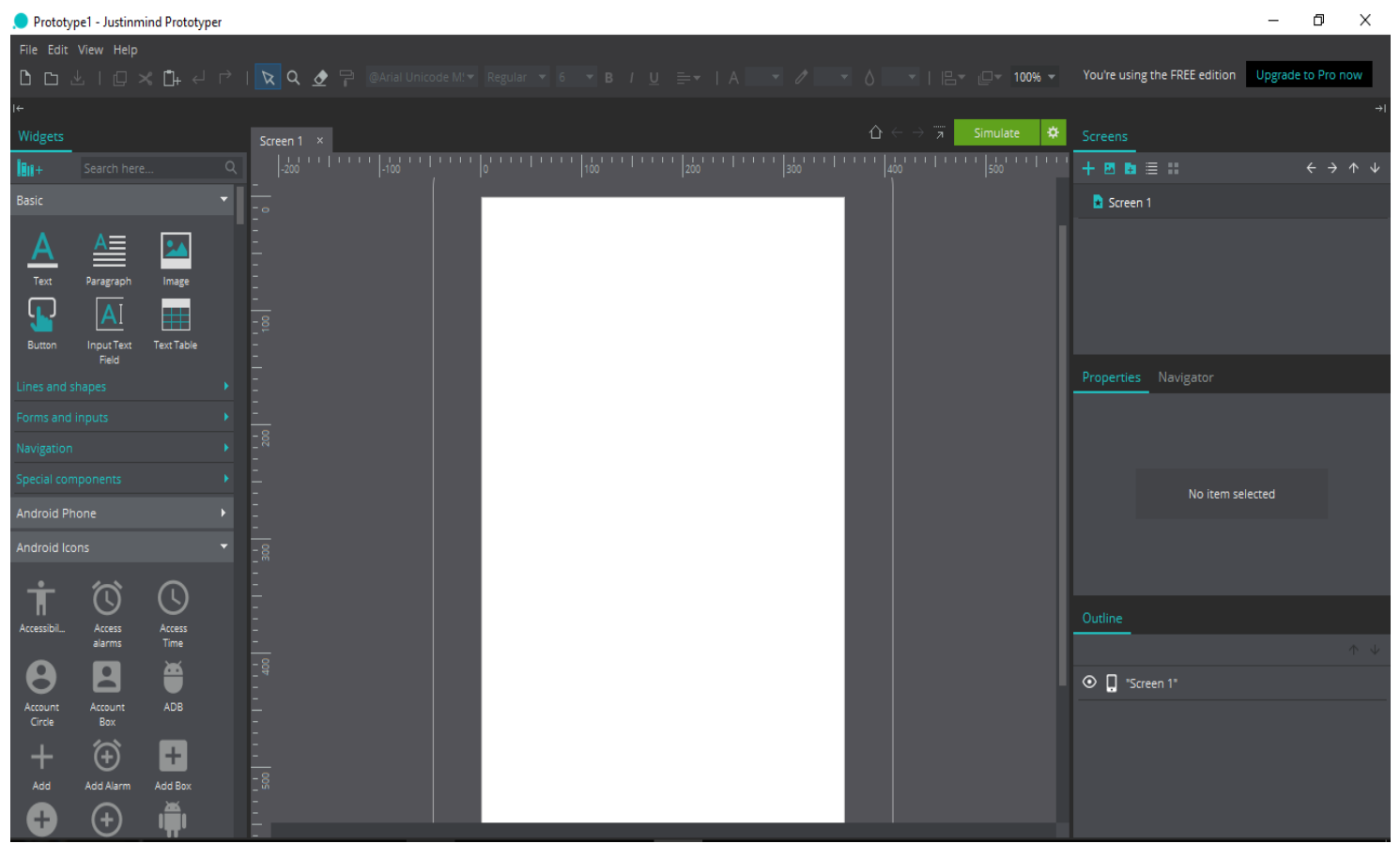

Figura 3-9 - Criação do primeiro protótipo em branco. 


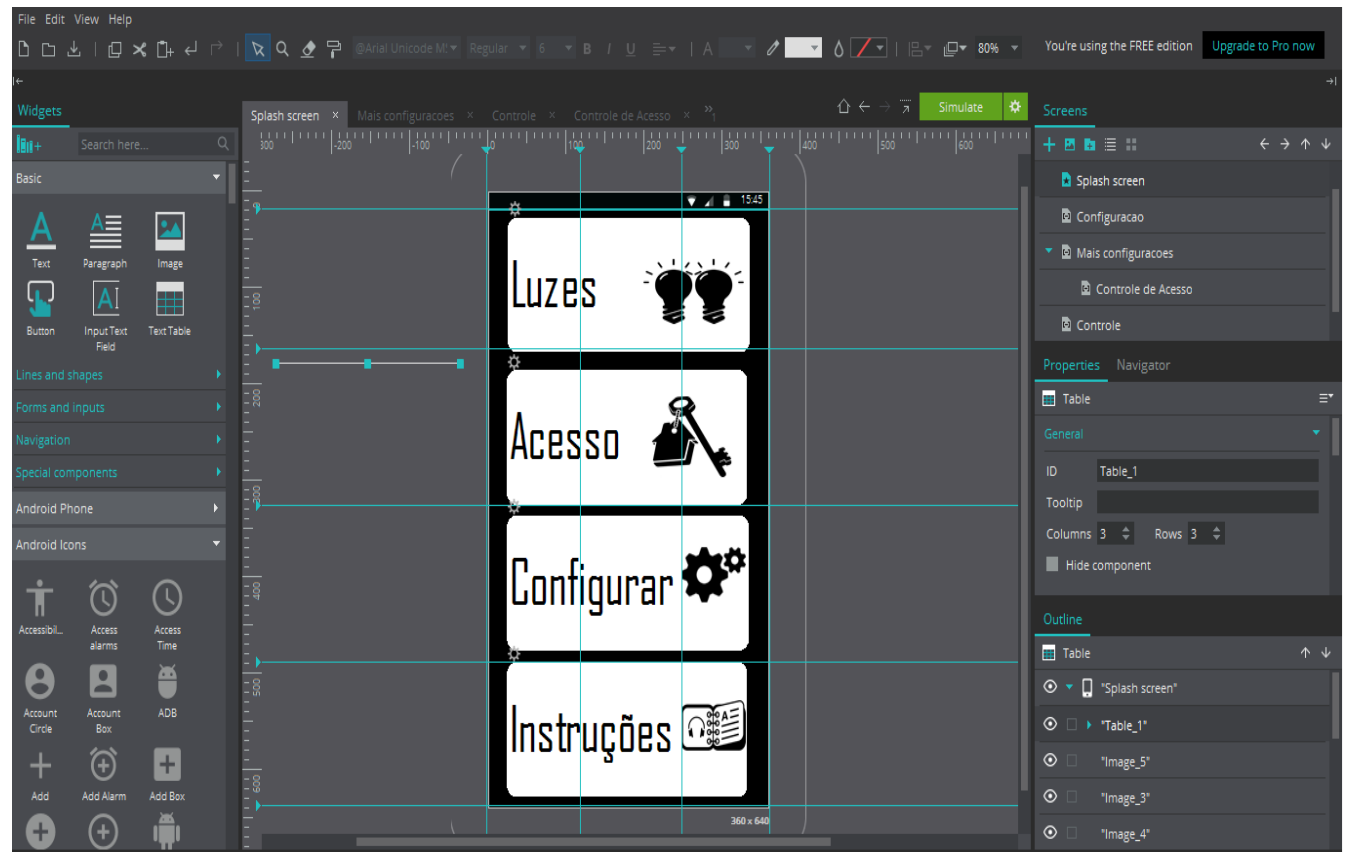

Figura 3-10 - Primeira Tela.

A ferramenta também dá suporte para simulação nos dispositivos reais graças ao Justinmind app $^{10}$. O Justinmind pode gerar protótipos HTML, que podem ser exibidos em qualquer navegador. A figura 3-11 mostra a simulação da interface por meio de um navegador.

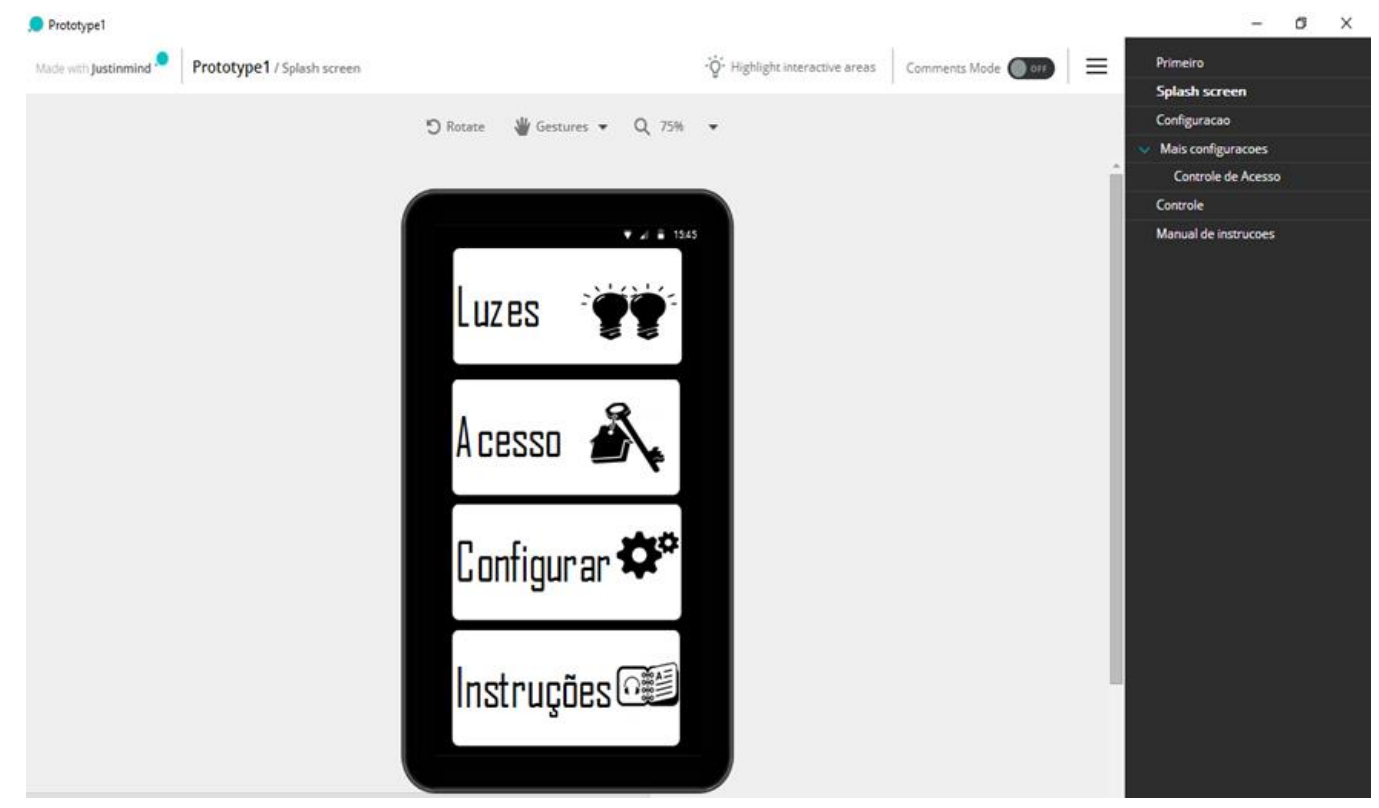

Figura 3-11 - Simulação da primeira tela gerada no navegador de preferência da pesquisadora.

\footnotetext{
${ }^{10} \mathrm{http}: / /$ www.justinmind.com/support/simulate-prototypes-multiple-devices/prepara
} 
Realizada a prototipagem, teve inicio a fase de criação do aplicativo. Para tanto, foi utilizada a plataforma gratuita do AppInventor ${ }^{11}$.

\subsubsection{Criação do aplicativo para dispositivo móvel com Sistema Operacional} Android para automação residencial com acessibilidade.

Para criar o aplicativo denominado Home Affordable - HA foi utilizado o App Inventor, uma aplicação web Open Source Release, mantida pelo Instituto de Tecnologia de Massachusetts (MIT). Esse aplicativo tem como filosofia seguir as diretrizes de acessibilidade do W3C e atender aos requisitos que satisfaçam as personas (João da Silva e Marina Cordeiro) no controle da automação residencial. Para tanto, foi utilizado o protótipo do projeto desenvolvido no Justinmind a fim de auxiliar no desenvolvimento da interface gráfica conforme pode ser observado na figura 3-12.

O App Inventor possibilita simulações feitas no próprio dispositivo móvel ou em um emulador disponibilizado pelo sítio. Para simulações no dispositivo móvel é necessário baixar o .apk que foi criado. É possível baixá-lo por meio de um $Q R$ code gerado pela própria plataforma do AppInventor ou salvar o .apk no próprio disco do computador e transferir via cabo USB para o dispositivo móvel como mostrado na figura 3-13. Por uma questão de facilidade foi utilizado o $Q R$ code e assim, puderam ser simuladas as várias versões do aplicativo no celular e realizar os ajustes que fossem necessários para que o projeto fosse adequado à realidade.

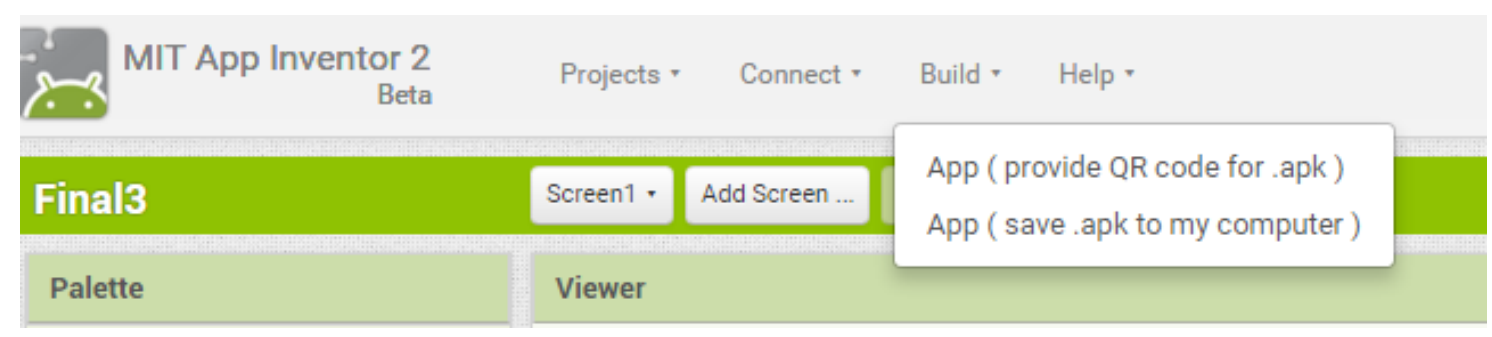

Figura 3-12 - Salvando o .APK

Cada camada (tela) é composta por um módulo designer e por um módulo blocks, como pode ser visto na figura 3-14. O módulo designer é a parte gráfica do aplicativo, a interface propriamente dita. O módulo blocks é a programação que está por traz desta interface. Essa realiza todas as ações necessárias para poder se comunicar com SAR e assim realizar o controle domótico. O módulo blocks pode ser visto na figura 3-15.

\footnotetext{
${ }^{11}$ http://appinventor.mit.edu/
} 


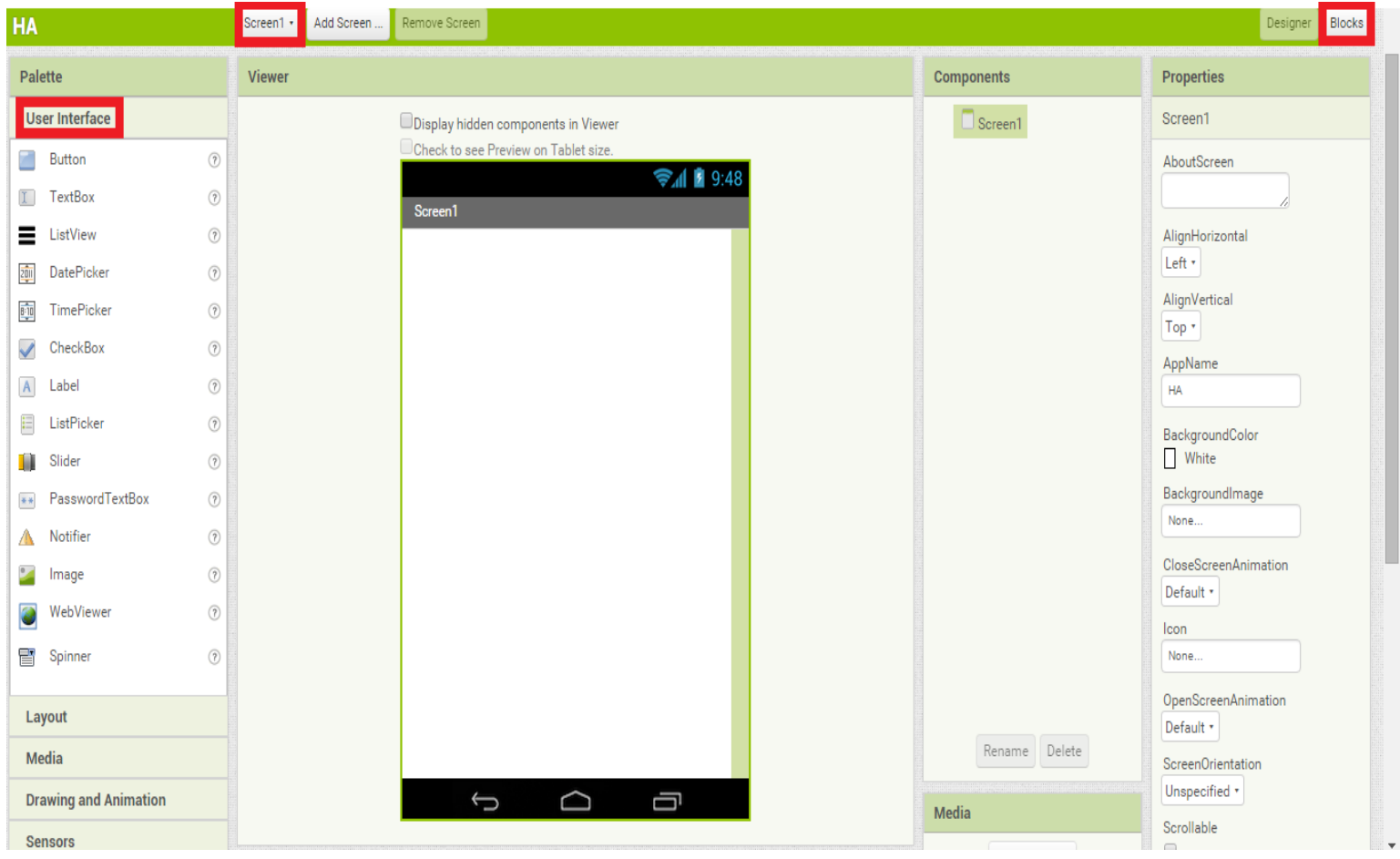

Figura 3-13 - Primeira Tela do AppInventor

As telas foram feitas com base nos esboços e no protótipo. A tela principal está representada na figura 3-14.

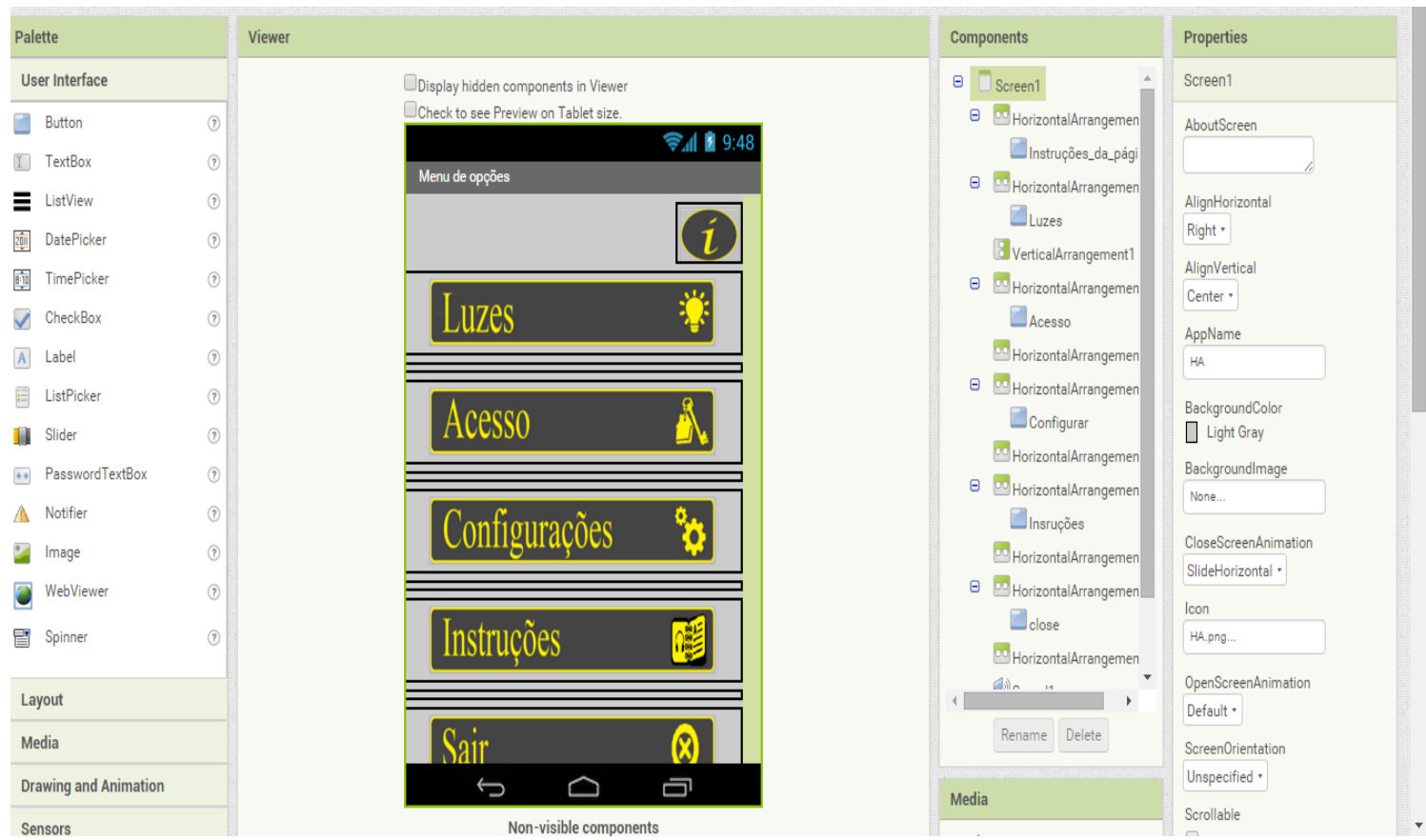

Figura 3-14 - Tela Principal. 


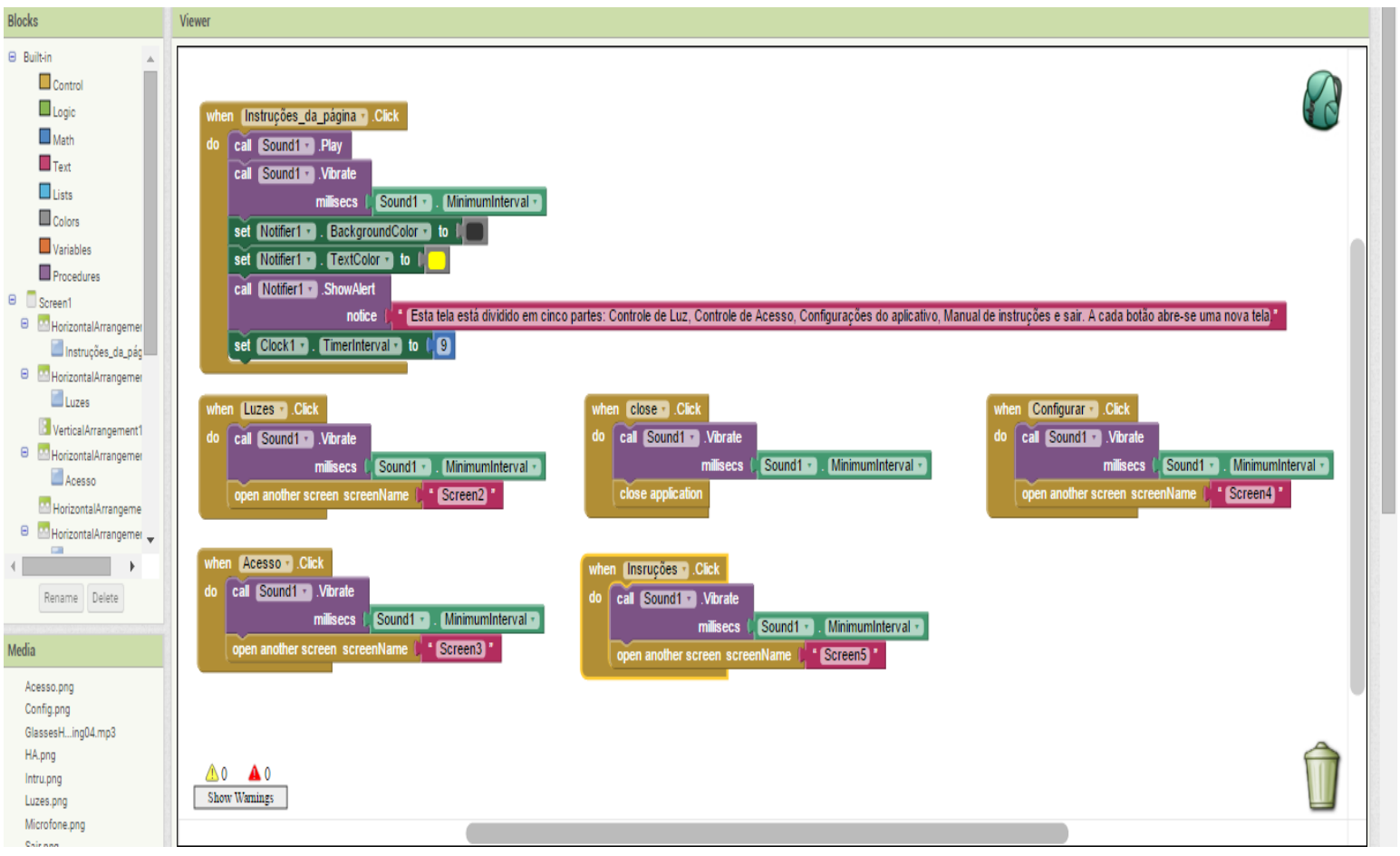

Figura 3-15 - Blocos de programação no App Inventor.

Após a criação de todas as telas necessárias, para que o aplicativo tivesse o controle residencial foi preciso dar inicio a fase dos testes entre o servidor e o aplicativo. Para isso foi montado o servidor de automação.

\subsubsection{Montagem da central de aplicação e fase de teste entre a central e o aplicativo HA.}

Para começar a fase dos testes, foi preciso montar e configurar a central de automação realizando todas as configurações relativas à conexão entre a rede WiFi e a central. Para isso, foi utilizado um script para configurar o módulo Ethernet e assim fazer com que houvesse uma comunicação adequada entre o roteador WiFi e o módulo Ethernet conjugado com o Arduino. Nesse caso, os quesitos de segurança foram reforçados para esse processo. Por exemplo, caso um oportunista consiga descobrir o endereço reservado para a aplicação e tente acessar os dispositivos da casa pela web, ele receberá um alerta de "acesso não autorizado", tal como descrito no script do módulo Ethernet apresentado na figura 3-16. 


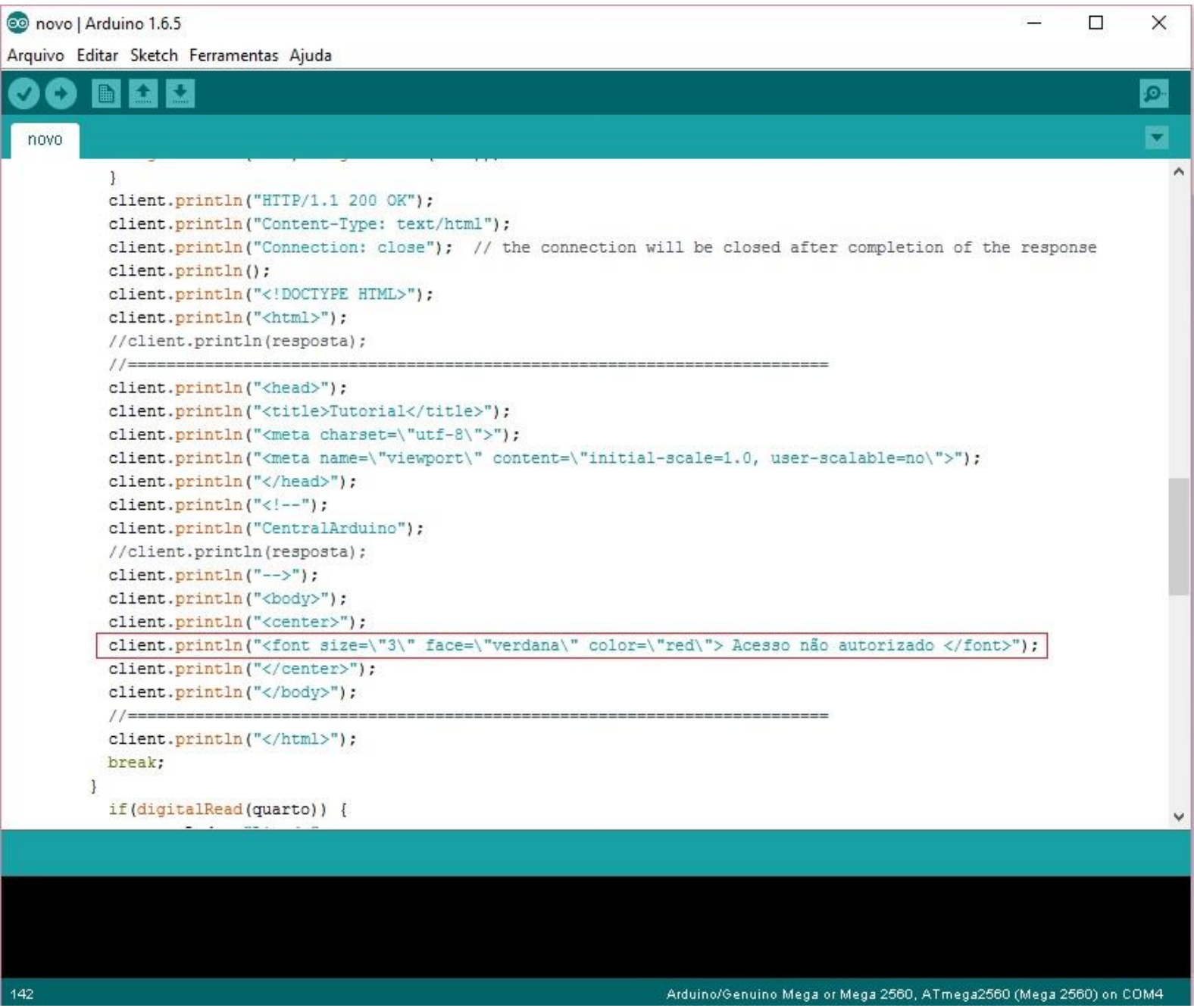

Figura 3-16 - Script Módulo Ethernet

Nas configurações do aplicativo, no campo digite o endereço de Rede/Host, o técnico configurará para o usuário um IP reservado no roteador WiFi. Esse endereço, assim que digitado e submetido, é salvo diretamente no Arduino.

Caso o usuário queira configurar um novo endereço de IP, poderá fazê-lo a qualquer momento. Para que os demais usuários da casa estejam conectados, todos deverão utilizar a mesma rede e o mesmo IP. O usuário e a senha do servidor também são gravados diretamente no servidor, e caso um usuário entre com uma senha errada este será impedido de acessar o sistema.

No caso do usuário perder o telefone ele poderá fazer novas configurações no novo celular, deixando inutilizáveis as configurações do celular antigo. Para o controle da porta é utilizado um cartão com NFC, no qual esse é previamente salvo no Arduino para que cada vez que o aplicativo leia o cartão a porta se abra. Caso haja perda do cartão o novo poderá ser 
devidamente salvo. A figura 3-17 mostra a tela de configurações do aplicativo de automação residencial HA.

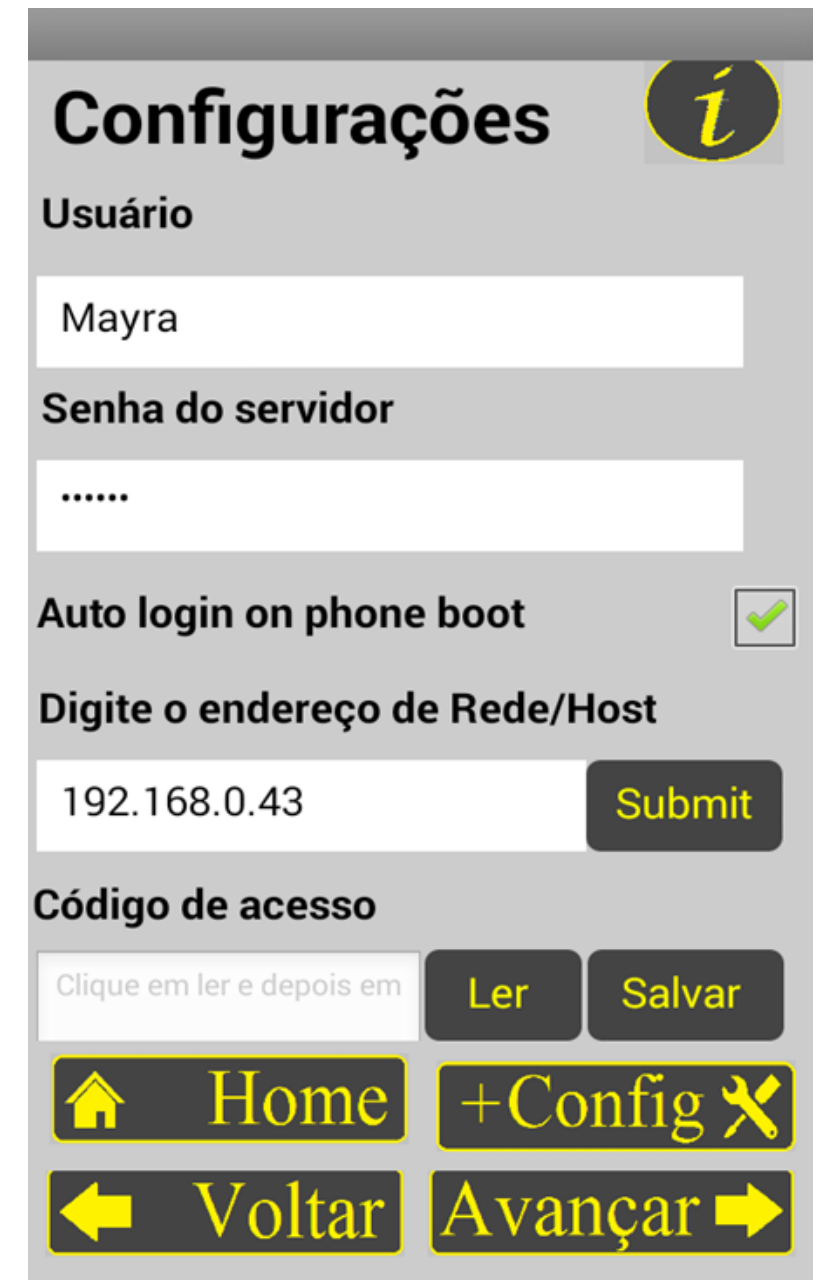

Figura 3-17 - Tela de configuração do HA

Depois de configurar a central de automação com o roteador $\mathrm{WiFi}$, foram instalados os sensores e atuadores, que melhor se ajustaram às necessidades do cliente. Posteriormente, foram realizados os testes entre o aplicativo $H A$ e os sensores e atuadores instalados na residência. A figura 3-18 mostra o modelo sugerido para automatizar uma residência com acessibilidade e baixo custo. 


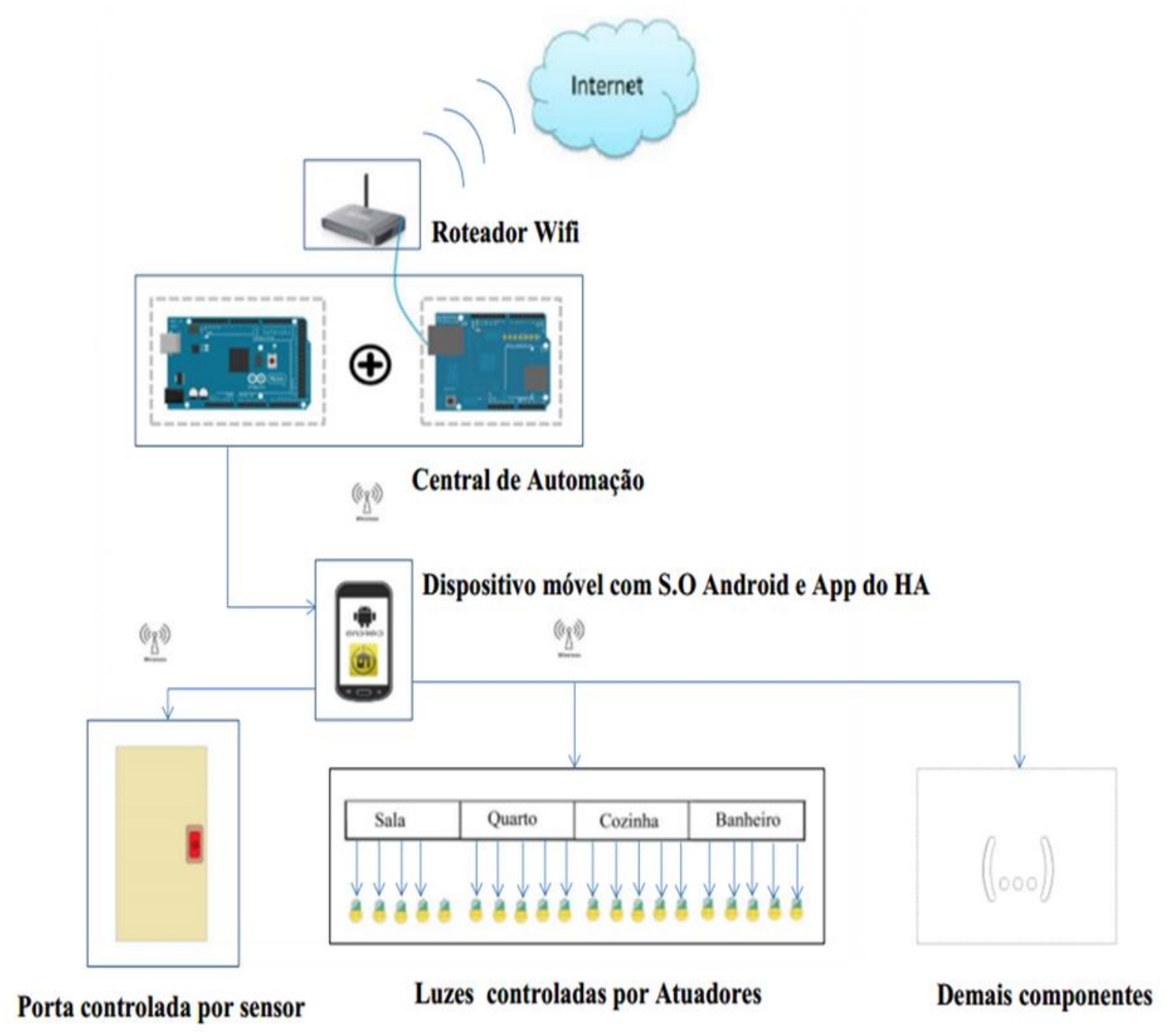

Figura 3-18 - Diagrama - Modelo de Automação

\subsection{Caso de uso}

Segundo a UML (Unified Modeling Language) um caso de uso é um conjunto de ações que um sistema desempenha para produzir um resultado observável de um valor a um ator específico (Jacobson, 1992). A técnica de modelagem descreve a funcionalidade de um sistema, no caso o SA, por meio de atores que interagem por meio de associações. Estes atores representa um papel e não um usuário individual do sistema.

A seguir será apresentada uma série de casos de uso referentes às possíveis interações dos usuários com o SA por meio da interface acessível, conforme apresentado na Figura 3-19. 


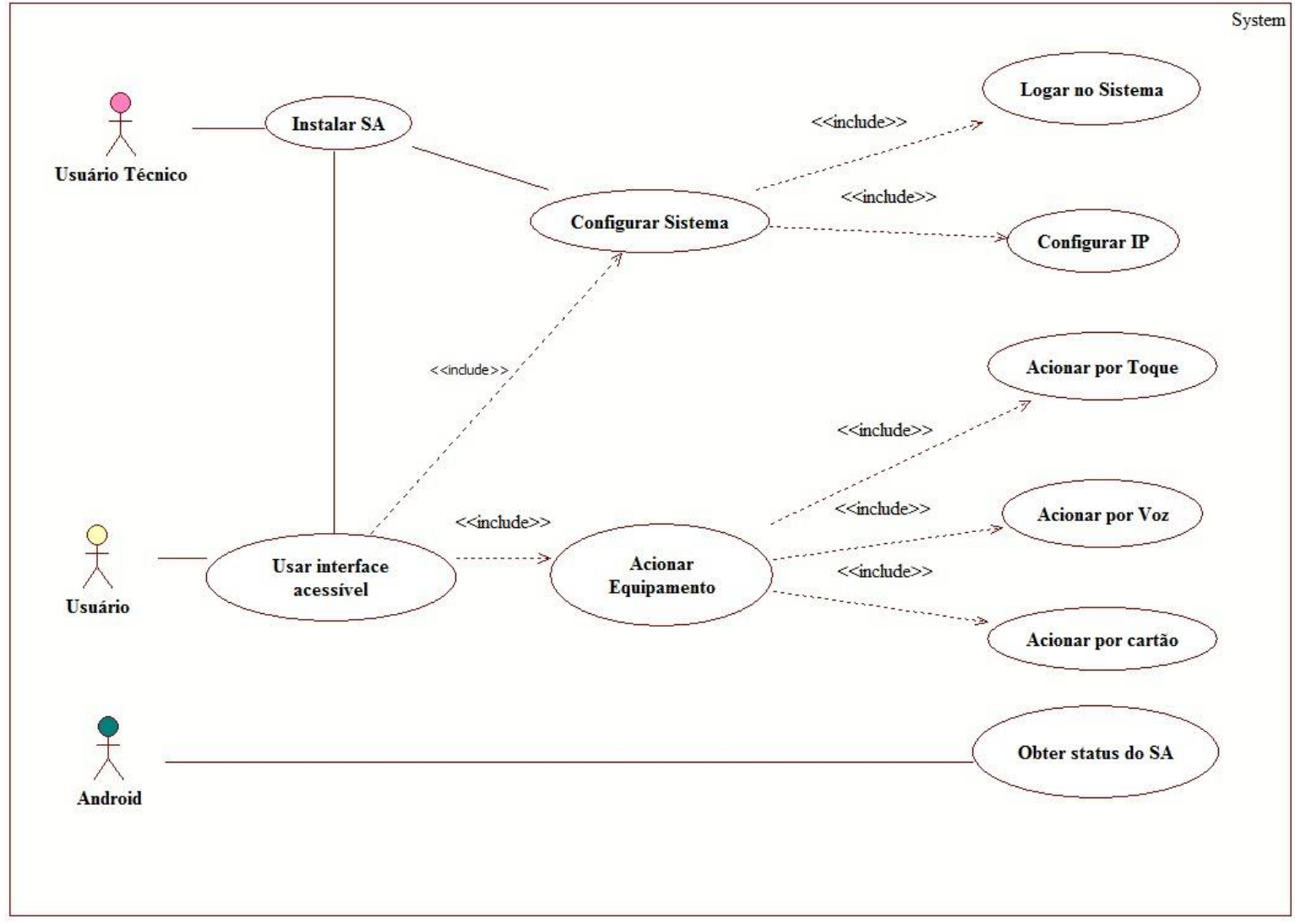

Figura 3-19 - Caso de Uso

\subsubsection{UC1 - Obter status do SA}

1. Descrição do caso de uso.

Esse caso de uso especifica o fluxo de ações para o usuário obter status do SA.

2. Atores do caso de uso.

2.1 Ator não humano - Sistema operacional Android que interage diretamente com o usuário humano e com o SA.

\section{Pré-Condições}

O SA deve estar devidamente instalado e configurado na casa do usuário por meio de uma rede LAN;

O usuário deve ter instalado o aplicativo HA no dispositivo móvel e estar autenticado em sua rede doméstica.

4. Fluxo de Eventos.

4.1. Fluxo Básico

F.1. O usuário acessa o sistema pelo HA. 
F.2. O HA mostra todas as ações que podem ser realizadas pelo usuário na tela de início.

F.3. O usuário escolhe entre o controle das luzes ou acesso [E.1] [E.2].

F.4. O HA envia um ou mais mecanismos de resposta ao usuário.

F.5. Os passos F.2, F.3. e F.4 são repetidos.

F.6. O caso de uso é encerrado quando o usuário sai do sistema.

\subsection{Exceção}

E.1. Para o primeiro acesso, faz-se necessário configurar usuário, senha, endereço de rede/host e o código NFC no menu configuração disposto na tela de início.

E.2. O sistema estende o caso de uso "Acionar dispositivo".

5. Pós - condições.

Não se aplica.

\subsubsection{UC2 Logar no Sistema}

1. Descrição do caso de uso.

Esse caso de uso especifica o fluxo de ações para o usuário, deficiente ou não, logar no sistema.

2. Atores do caso de uso.

2.1 Usuário com ou sem deficiência total.

Ator humano com ou sem deficiência visual, que interage diretamente no sistema por meio de interface acessível realizando os procedimentos necessários para o controle e acionamento dos dispositivos de uma rede domótica ou predial.

\subsection{Usuário Técnico}

Ator humano com ou sem deficiência visual, que interage diretamente no sistema para configurar o HA e realizar os procedimentos necessários para logar no sistema.

\section{Pré-Condições}

O SA deve estar devidamente instalado e configurado na casa do usuário por meio de uma rede LAN;

O usuário deve ter instalado o aplicativo - HA no dispositivo móvel, com sistema operacional Android, versão mínima de 4.0; 
O usuário deve possuir a função de NFC no dispositivo móvel para poder acessar o portão de entrada;

O usuário deve se conectar ao sistema pela rede Wi-Fi por meio do HA instalado no dispositivo móvel.

4. Fluxo de Eventos

4.1. Fluxo Básico

F.1. O sistema verifica se a rede Wi-Fi está disponível.

F.2. O usuário acessa o sistema por meio do ícone do aplicativo disposto na área de trabalho.

F.3. O aplicativo tem acesso ao mепи inicial.

F.4. O usuário tem acesso ao controle dos dispositivos do sistema.

F.5. O usuário pode voltar à tela de início ou próxima tela a qualquer momento [E.1].

F.6. Os passos F.3, F.4. e F.5. são repetidos.

F.7. O caso de uso é encerrado quando o usuário clica no botão sair do sistema.

\subsection{Exceções.}

E.1. Caso o usuário esteja na tela Controle de Luzes o botão voltar irá para o menu inicial não tendo assim botão home nessa tela.

5. Pós - condições.

O usuário terá acesso às configurações do aplicativo HA e todo o controle dos dispositivos do sistema.

\subsubsection{UC3 Acionar dispositivo}

1. Descrição do caso de uso

Esse caso de uso especifica o fluxo de ações para o usuário acionar e controlar os dispositivos de forma individual ou simultânea, por uma rede LAN, com o aplicativo HA.

2. Atores do caso de uso

2.1. Usuário com ou sem deficiência total.

3. Pré-Condições

O usuário deve se conectar ao sistema pela rede Wi-Fi por meio do HA instalado no dispositivo móvel. 
4. Fluxo de Eventos

4.1. Fluxo Básico

F.1. O usuário escolhe entre a opção de controle de luzes ou acionamento do portão por voz, por toque ou por cartão [E.1], [E.2] [E.3] [E.4].

F.2. O sistema dá ao comando do usuário um ou mais mecanismos de resposta indicando sucesso ou falha.

F.3. O caso de uso é encerrado quando o usuário sai do sistema.

\subsection{Exceções}

E.1. O sistema estende o caso de uso "Acionar dispositivo lâmpada por toque"

E.2. O sistema estende o caso de uso "Acionar dispositivo portão por cartão".

E.3. O sistema estende o caso de uso "Acionar dispositivo lâmpada/portão por voz".

E.4. O sistema estende o caso de uso "Configurar Sistema".

5. Pós - condições

O usuário terá o controle das lâmpadas e do acesso do portão.

\subsubsection{UC4 Acionar dispositivo lâmpada.}

1. Descrição do caso de uso

Esse caso de uso especifica o fluxo de ações para o usuário acionar ligar/ desligar as lâmpadas individuais ou simultâneas por uma rede LAN com o HA.

2. Atores do caso de uso

2.2. Usuário com ou sem deficiência total.

3. Pré - condições

O usuário deve estar autenticado na rede doméstica por meio do HA. O usuário deve se conectar ao sistema pela rede Wi-Fi por meio do HA instalado no dispositivo móvel.

4. Fluxo de Eventos

4.1. Fluxo Básico

F.1. O usuário escolhe entre a opção de controle de luzes na tela de início.

F.2. O sistema apresenta os cômodos da residência e os dispositivos em cada cômodo que podem ser controlados pelo usuário. 
F.3. O usuário poderá selecionar um ou mais dispositivos individualmente ou simultaneamente em um ou mais cômodos, que serão controlados por meio do HA [E.1].

F.4. O usuário dá o comando de ligar/desligar no(s) cômodo(s) escolhido. [E.2] [E.3]

F.5. O sistema dá ao comando do usuário um ou mais mecanismos de resposta indicando sucesso ou falha. [E.4] [E.5].

F.6. O caso de uso é encerrado quando o usuário sai do sistema.

\subsection{Exceções}

E.1. O sistema estende o caso de uso "Acionar dispositivo lâmpada/portão por voz".

E.2. O usuário pode acionar todos os dispositivos simultaneamente.

E.3. O usuário poderá desligar todas as luzes caso exista ao menos uma luz acesa.

O usuário poderá ligar todas as luzes caso exista ao menos uma luz apagada.

E.4. O status do botão modifica a cada ação realizada com sucesso.

E.5. O sistema estende o caso de uso "Configurar Sistema".

5. Pós - condições

O usuário terá controle dos dispositivos nos cômodos simultaneamente ou individualmente.

\subsubsection{UC5 Acionar dispositivo portão.}

1. Descrição do caso de uso

Esse caso de uso especifica o fluxo de ações para o usuário acionar o portão pela rede LAN utilizando a função NFC do celular e o cartão com NFC no aplicativo HA.

2. Atores do caso de uso

2.3. Usuário com ou sem deficiência total.

3. Pré-Condições

O Usuário deve estar autenticado na rede doméstica por meio do HA.

O Usuário deve ter a função NFC no celular.

O Usuário deve ter cadastrado o NFC nas configurações do celular.

4. Fluxo de Eventos

4.1. Fluxo Básico

F.1. O usuário escolhe entre a opção de Acesso ao portão na tela de início. 
F.2. O sistema apresenta o local indicado para que usuário posicione seu cartão NFC [E.1].

F.3. O sistema dá ao comando do usuário um ou mais mecanismos de resposta indicando sucesso ou falha.

F.4. O caso de uso é encerrado quando o usuário sai do sistema.

\subsection{Exceções}

E.1. O sistema estende o caso de uso "Acionar dispositivo lâmpada/portão por voz".

5. Pós - condições

O usuário terá controle e acionamento do dispositivo portão.

\subsubsection{UC6 Acionar dispositivo - lâmpada/portão, por voz.}

1. Descrição do caso de uso

Esse caso de uso especifica o fluxo de ações para o usuário acionar um ligar/desligar as lâmpadas, individuais ou simultâneas ou acionar um dispositivo portão em uma rede LAN com o HA.

2. Atores do caso de uso

2.4. Usuário com ou sem deficiência total.

\section{Pré-Condições}

O Usuário deve estar autenticado na rede doméstica por meio do HA. O usuário deve se conectar ao sistema pela rede Wi-Fi por meio do HA instalado no dispositivo móvel.

4. Fluxo de Eventos

4.1. Fluxo Básico

F.1. O usuário escolhe entre a opção de controle de luzes na tela de início.

F.2. O sistema apresenta na tela as opções de controle e acionamento possíveis.

F.3. O usuário seleciona a opção comando por voz.

F.4. O sistema abre nova tela.

F.5. O usuário dá o comando desejado ligar/desligar luzes, acionar portão por voz.

F.6. O sistema dá ao usuário como mecanismo de resposta seu comando em forma de texto [E.1]

F.7. O caso de uso é encerrado quando o usuário sai do sistema. 

4.2. Exceções
E.1. O sistema estende o caso de uso "Configurar Sistema".

5. Pós - condições.

O usuário terá controle dos dispositivos nos cômodos simultaneamente ou individualmente ou do acionamento do portão.

\subsubsection{UC7 Configurar Sistema.}

1. Descrição do caso de uso

Esse caso de uso especifica o fluxo de ações para o usuário configurar o sistema com o HA.

2. Atores do caso de uso

2.1. Usuário técnico.

2.2. Usuário com ou sem deficiência visual.

\section{Pré-Condições}

O usuário deve se conectar ao sistema pela rede Wi-Fi por meio do HA instalado no dispositivo móvel.

4. Fluxo de Eventos

4.1. Fluxo Básico

F.1. O usuário escolhe a opção configurar na tela de início.

F.2. O sistema apresenta na tela as opções de configuração possíveis.

F.3. O usuário faz as configurações necessárias para o controle e acionamento dos dispositivos [E.1].

F.4. O usuário submente as informações.

F.5. O sistema dá ao comando do usuário um ou mais mecanismos de resposta indicando sucesso ou falha.

F.6. O caso de uso é encerrado quando o usuário sai do sistema.

\subsection{Exceções \\ E.1 O sistema estende o caso de uso "Mais Configurações".}

5. Pós - condições.

O usuário poderá controlar os dispositivos com êxito. 


\subsubsection{UC8 Mais Configurações.}

1. Descrição do caso de uso

Esse caso de uso especifica o fluxo de ações para o usuário configurar os mecanismos de resposta do HA.

2. Atores do caso de uso

2.3. Usuário técnico.

2.4. Usuário com ou sem deficiência visual.

3. Pré-Condições

O usuário deve se conectar ao sistema pela rede Wi-Fi por meio do HA instalado no dispositivo móvel.

4. Fluxo de Eventos

\subsection{Fluxo Básico}

F.1. O usuário escolhe a opção configurar na tela de início.

F.2. O sistema apresenta na tela as opções de configuração possíveis.

F.3. O usuário escolhe a opção de mais configurações disposta na tela.

F.4. O sistema abre tela de mais configurações.

F.5. O sistema mostra todos os possíveis mecanismos de resposta que podem ser escolhidos.

F.6. O usuário seleciona os mecanismos de resposta.

F.7. O usuário escolhe voltar à tela de configurações ou ir para a tela de início.

F.8. O caso de uso é encerrado quando o usuário sai do sistema.

\subsection{Exceções}

Não se aplica.

5. Pós - condições.

O usuário terá os dispositivos de resposta selecionados.

\subsection{Conclusões do capítulo}


Esse capítulo apresentou os principais métodos utilizados para projetar uma interface acessível para o controle domótico por PDV. Foram detalhados os principais conceitos e mecanismos de coleta de dados descritos no capítulo 2.

Pela inviabilidade de abranger todo o país foi delimitado o Distrito Federal como espaço amostral a ser estudado. Com base nos dados oficiais do censo 2010, 52,79\% dos deficientes visuais tem renda entre um a dois salários mínimos. A fim de atender a todas as classes econômicas esse projeto foi orçado em $\mathrm{R} \$ 257,8$.

Nesse capítulo foi detalhado como ocorreram os pré-testes nas dependências da UnB e do CEEDV. Foram mostrados os métodos e as tarefas que cada cenário deveria realizar para concluir as atividades requeridas. Em cada localidade houve em seus pré-testes cenários e atividades distintas, com finalidades específicas para obter e avaliar os dados que servirão de base na criação das personas que irão auxiliar a formulação e criação da interface desejada.

Também foi apresentado a método de criação do aplicativo que fará a interface entre o usuário e o controle domótico. Ao final foram apresentados e sugeridos os passos que levaram ao modelo para automatizar uma residência com acessibilidade a preços baixos. 


\section{RESULTADOS DO PROJETO}

\subsection{Resultados alcançados durante os pré-testes com os alunos da Universidade de Brasília - UNB}

O pré-teste realizado nas dependências na UnB teve participação de homens e mulheres, sem deficiência visual, estudantes de mestrado e do doutorado da própria universidade. A maioria destes estudantes trabalhava em suas respectivas áreas de formação, sendo que 90\% pertenciam ao setor público. A média das idades foi de 30,4 anos como mostrado na Tabela 4-1.

Tabela 4-1 - Média das idades dos alunos

\begin{tabular}{|c|c|c|c|c|c|c|c|c|c|c|c|c|c|c|c|c|c|c|c|c|c|}
\hline $\begin{array}{c}\mathbf{N}^{\mathbf{0}} \text { de } \\
\text { pessoas }\end{array}$ & $\mathbf{1}$ & $\mathbf{2}$ & $\mathbf{3}$ & $\mathbf{4}$ & $\mathbf{5}$ & $\mathbf{6}$ & $\mathbf{7}$ & $\mathbf{8}$ & $\mathbf{9}$ & $\mathbf{1 0}$ & $\mathbf{1 1}$ & $\mathbf{1 2}$ & $\mathbf{1 3}$ & $\mathbf{1 4}$ & $\mathbf{1 5}$ & $\mathbf{1 6}$ & $\mathbf{1 7}$ & $\mathbf{1 8}$ & $\mathbf{1 9}$ & $\mathbf{2 0}$ & $\begin{array}{c}\overline{\mathbf{X}} \text { das } \\
\text { idades }\end{array}$ \\
\hline Idade & 27 & 29 & 30 & 31 & 28 & 35 & 36 & 30 & 29 & 28 & 31 & 30 & 31 & 29 & 31 & 32 & 30 & 30 & 32 & 29 & 30,4 \\
\hline
\end{tabular}

Após apresentação da proposta do trabalho, os alunos puderam escolher um dos cenários da Tabela 3-3 para realizar o pré-teste. Auxiliando na escolha dos alunos em cada cenário, foram estabelecidos os dispositivos de entrada ou saída que poderiam ser utilizados ou não, conforme a Tabela 4-2.

Tabela 4-2 Uso de dispositivos de entrada/saída

\begin{tabular}{|c|c|c|c|}
\hline Dispositivos de saída & Cenário 1 & Cenário 2 & Cenário 3 \\
\hline Monitor & Não & Sim & Sim \\
\hline Mouse & Não & Sim & Não \\
\hline Teclado & Sim & Sim & Sim \\
\hline Caixas de som/ Fone & Sim & Não & Não \\
\hline Software NVDA & Sim & Não & Não \\
\hline
\end{tabular}

\subsection{Resultados e Análise dos pré-testes}

\subsubsection{Descrição dos resultados}

Antes de começar o teste, todos os alunos relataram que faziam uso de computadores e dispositivos móveis para uso pessoal, lazer, trabalho e estudos. Dessa maneira, ficou a critério dos alunos escolherem quais equipamentos eletrônicos utilizar durante o teste. É importante salientar que o teste foi totalmente voluntário, sem fins lucrativos, apenas didáticos, mas 
mesmo assim, houve adesão de $100 \%$ da turma. Após escolher o aparelho eletrônico e relatar familiaridade, ao serem privados de um dos dispositivos de entrada/saída os alunos tiveram muitas dificuldades na realização das tarefas. Algumas observações foram comprovadas durante o pré-teste, em que as mesmas podem ser visualizadas na Tabela 4-3.

Tabela 4-3 - Observação entre os cenários

\begin{tabular}{|l|c|c|c|}
\hline \multicolumn{1}{|c|}{ Parâmetros } & Cenário 1 & Cenário 2 & Cenário 3 \\
\hline Conheciam as teclas de atalho & $5 \%$ & $0 \%$ & $10 \%$ \\
\hline Não precisou de mouse & $5 \%$ & $0 \%$ & $5 \%$ \\
\hline Conseguiram utilizar o NVDA & $15 \%$ & - & - \\
\hline Realizou cada tarefa > 3 vezes & $100 \%$ & $100 \%$ & $100 \%$ \\
\hline Conseguiu realizar uma tarefa & $10 \%$ & $60 \%$ & $55 \%$ \\
\hline Conseguiu realizar todas as tarefas & $5 \%$ & $0 \%$ & $15 \%$ \\
\hline Área de atuação - Ciências Humanas & $90 \%$ & $95 \%$ & $10 \%$ \\
\hline Área de atuação - Ciências Exatas & $10 \%$ & $5 \%$ & $90 \%$ \\
\hline
\end{tabular}

O NVDA foi um facilitador nas tarefas do Grupo1. Com uma breve explanação de como o software funcionava, $15 \%$ dos alunos conseguiram utilizá-lo, sendo que $5 \%$ conseguiram finalizar o pré-teste, havendo ainda a necessidade de realizar a mesma tarefa mais de três vezes até concluí-la.

O uso do software poderia ter ajudado ainda mais os alunos e com mais eficiência se não houvesse problemas de compatibilidade com o sistema operacional Windows 8. O NVDA não conseguiu ler todas as informações da tela e por isso, alguns alunos ficavam confusos, gerando ansiedade e até mesmo fazendo com que alguns desistissem do pré-teste.

Outro ponto que ficou evidenciado durante o pré-teste foi o desconhecimento das teclas de atalho por mais de $90 \%$ dos alunos. Sem ter conhecimento do teclado, a maioria queria utilizar o mouse por sua facilidade e comodismo. Dos alunos que tinham algum conhecimento das teclas de atalhos verificou-se que mais de $95 \%$ pertencia a área de exatas.

No fim dos pré-testes os voluntários relataram que em seus trabalhos o tempo de execução de cada tarefa era importante e por isso, o uso do mouse acabava sendo dispensado. Ficou evidente, que os alunos que não conheciam ou que conheciam poucas teclas de atalho relataram mais dificuldade que os alunos que tinham tal conhecimento. 
Para o segundo cenário, os comentários ficaram concentrados na falta de acessibilidade do sítio. Como esse não possuía o módulo de acessibilidade recomendado pelo W3C e também porque não havia nenhuma forma de alerta sobre a ausência de acessibilidade, os alunos perderam muito tempo procurando como colocar no sítio o módulo de acessibilidade. Isso causou desconforto e irritabilidade. Muitos voluntários não conseguiram finalizar todas as tarefas. O maior exemplo disso foi a tarefa de assistir ao vídeo, que por não possuir legendas acabou desmotivando muitos dos alunos a assistirem até o final.

Por outro lado, a comparação entre a matéria escrita e a do vídeo foi uma tarefa impossível. Alguns alunos fizeram inferências que sugeriam tratar-se da mesma matéria, mas sem a legenda não se pôde ter certeza. No contexto geral, a maioria dos voluntários sentiramse frustrados, confusos, perdidos e desmotivados.

O terceiro cenário foi composto pela maioria dos alunos das ciências exatas, cerca de $90 \%$. Foi notada maior desenvoltura na realização das tarefas que precisavam das teclas de atalho, porém, como a simulação envolvia mobilidade reduzida das mãos, o aluno ficou impedido de utilizar as duas mãos.

Nesses casos seria necessário o uso de ponteiras de boca, sistema de fixação MentoOccipital com hastes telescópicas, entre outros no auxílio desse tipo de deficiência. Porém, na falta desses instrumentos os alunos foram convidados a utilizar uma caneta segurando-a pela boca.

O mouse também não foi liberado para o terceiro cenário. Quando era preciso utilizar as teclas de atalho os alunos utilizavam uma caneta como auxiliar. Os alunos que participaram desse pré-teste sentiram dificuldade para realizar as tarefas, porém não se sentiram frustrados. Nesse caso, o sentimento mais relatado foi de raiva por ter que realizar a tarefa mais de uma vez.

Todos os alunos tiveram de realizar a mesma tarefa mais de uma vez, pois não conseguiam utilizar a caneta como auxílio. Mais de 50\% dos alunos conseguiram realizar pelo menos uma tarefa por completo e $15 \%$ realizaram todas as tarefas. Esse número poderia ter sido maior se muitos usuários não tivessem desistido de realizar as tarefas depois de consecutivos erros. 


\subsubsection{Análise dos Resultados}

a) As observações durante os pré-testes puderam constatar que:

1) O sítio analisado não seguiu as diretrizes de acessibilidade do W3C. Além disso, não foi encontrado nenhum alerta da ausência de acessibilidade, demostrando um total descaso com o usuário com deficiente.

2) A falta de acessibilidade nos sítios realmente gera dificuldades ou até mesmo impedimentos no acesso à informação para os usuários com deficiências. O maior exemplo deste pré-teste foi o vídeo sem legendas que tornou quase que impossível o entendimento dos alunos que simularam os deficientes auditivos.

3) O fato de o sítio analisado ser tabular, descumprindo as normas do W3C e a maioria dos alunos não conhecerem as teclas de atalho dificultou o acesso às abas, menus e caixas suspensas. Além disso, durante todo pré-teste não foi encontrada nenhuma figura com descrição. Os alunos que simularam os UDV, mesmo utilizando o NVDA muitas vezes não conseguiam entender a disposição dos elementos na tela pela falta de descrição dos ícones, das figuras e dos links. A tabulação feita pelo sítio fez os alunos perderem muito tempo procurando as notícias.

4) As ferramentas de leitura de tela são indispensáveis e por isso, deve-se prestar atenção para verificar se as novas versões dos sistemas operacionais são compatíveis com os softwares com essa função.

5) O grande índice de desistência do pré-teste foi devido à dificuldade da realização das tarefas sem o uso do mouse. A maior parte dos alunos ficava impaciente por ter que realizar a mesma tarefa mais de três vezes, gerando grande desconforto e frustração.

6) Os alunos tomaram consciência de como é utilizar uma interface sem acessibilidade.

7) Os alunos concordaram em unanimidade com a premissa de que as interfaces devem atender a todos.

\section{b) Observações e considerações dos alunos após os pré-testes:}

1) Todos os alunos utilizavam computadores e dispositivos móveis diariamente e se sentiram aptos a realizar o pré-teste, porém, quando começaram a se deparar com as dificuldades cerca de $60 \%$ dos alunos pensaram em desistir na terceira tentativa.

2) Cerca de $80 \%$ dos alunos desconheciam os problemas referentes à acessibilidade na internet, principalmente nas páginas web. Mais da metade dos alunos, $65 \%$ não tinham conhecimento que os PDV faziam o uso de sítios com regularidade, principalmente nos dispositivos móveis. 
3) A respeito do design visceral, o pré-teste gerou sentimentos de raiva, desespero, ansiedade e frustação, sendo esse o sentimento mais relatado pelos alunos. 95\% se sentiram frustrados por não conseguirem realizar as tarefas sugeridas.

4) Os alunos relataram que a falta de acessibilidade é um problema que atrapalhou a realização do pré-teste. Mais de $95 \%$ dos alunos não imaginavam que existia tamanha dificuldade em realizar uma tarefa ao impossibilitar um dos sentidos. Esses alunos imaginavam que conseguiriam realizar as tarefas com facilidade. Apenas os alunos que realizaram o pré-teste do primeiro cenário relataram que imaginaram que teriam alguma dificuldade, porém no momento da explicação do pré-teste acharam que iriam concluir a tarefa no tempo da aula por utilizar o NVDA.

5) Dos alunos que participaram do primeiro cenário, mais de $65 \%$ desconheciam ou nunca haviam ativado os recursos assistivos talkback do Android ou VoiceOver do iOs.

6) Todos os alunos concordaram que se devem respeitar as diretrizes do $\mathrm{W} 3 \mathrm{C}$ e se o sítio utilizado tivesse acessibilidade teria sido mais fácil a realização das tarefas.

Para fim dessa pesquisa foi utilizado como base o cenário de UDV, porém as informações obtidas nos demais cenários auxiliaram na construção do design visceral do personagem. Após as observações feitas durante e após o pré-teste foi possível criar uma persona, João da Silva, que aglutina as características mais relevantes observadas no design visceral dos grupos nas necessidades de acessibilidade. Para tanto, João não possui deficiência visual, mas utilizará o mesmo aplicativo que os PDV utilizarão.

\subsubsection{Descrição da persona João tendo por base os pré-testes realizados na UnB}

Com base nas entrevistas, observações e pré-testes abordados no método adotado foi possível detalhar o perfil do usuário, suas dificuldades e facilidades perante a situação teste estabelecida. A partir da análise das respostas obtidas, puderam ser unificas as informações e elaborado uma personagem em um documento detalhado na Tabela 4-4. João da Silva foi o nome dado à persona criada para facilitar a elaboração dos melhores métodos de projeto para interfaces acessíveis que visam atender os usuários com e sem deficiência visual.

A Tabela 4-4 detalha a persona João da Silva por gravura e descrição. Gerada de acordo com os pré-testes realizados. A tabela está dividida em duas colunas, o lado esquerdo com a ilustração da persona sem deficiência visual e o lado direito pela descrição que define o 
usuário criado. Para a criação do João, Figura 4-1, foi levado em consideração os usuários que realizaram o pré-teste do Cenário1.

Tabela 4-4 - Persona João, usuário sem deficiência visual.

\begin{tabular}{|c|c|}
\hline & Nome: João da Silva. \\
\hline & Idade: 30 anos. \\
\hline & Escolaridade: Cursando Mestrado. \\
\hline & Residência: No DF. \\
\hline & Estado civil: Casado com filhos. \\
\hline & Trabalho: Setor público. \\
\hline & $\begin{array}{l}\text { Conhecimento de informática: Considera-se } \\
\text { uma pessoa com conhecimentos } \\
\text { satisfatórios na área de informática. } \\
\text { Consegue realizar uma pesquisa, acessar um } \\
\text { vídeo, criar e editar um texto, planilhas, } \\
\text { entre outros. } \\
\text { Usa o computador em suas tarefas diárias, } \\
\text { no trabalho, para estudar e para seu laser. }\end{array}$ \\
\hline & $\begin{array}{l}\text { Perfil: João se considera uma pessoa } \\
\text { comunicativa e capacitada a exercer sua } \\
\text { função com o auxilio do computador. }\end{array}$ \\
\hline Figura 4-1 - João da Silva & $\begin{array}{l}\text { Design Emocional: Durante os pré-testes o } \\
\text { usuário se sentiu desafiado e motivado a } \\
\text { realizar a atividade, porém ele não } \\
\text { conseguiu terminar as tarefas. João não } \\
\text { conseguiu usar as teclas de atalho do } \\
\text { computador, não conhecia o teclado e sem } \\
\text { poder enxerga-lo, quis desistir por vários } \\
\text { momentos. Sem o uso do mouse, teve } \\
\text { dificuldades primárias. Não conseguiu abrir, } \\
\text { fechar e nem navegar pelo sítio sugerido. } \\
\text { João chegou a tentar realizar a tarefa com } \\
\text { seu celular/tablet, mas nem assim conseguiu } \\
\text { terminar e desistiu da atividade. João se } \\
\text { sentiu insatisfeito, decepcionado, pensativo }\end{array}$ \\
\hline
\end{tabular}




\begin{tabular}{|l|l|}
\hline e, principalmente, frustrado fazendo \\
repensar sobre algumas coisas que ele \\
considerava fáceis. Depois do teste ele \\
considerou a possibilidade de aprender \\
novas formas de manusear seu computador. \\
\hline $\begin{array}{l}\text { Ao ser colocado em um ambiente diferente } \\
\text { do qual ele estava acostumado, um } \\
\text { ambiente sem acessibilidade, ele pôde } \\
\text { perceber quão difícil pode ser a vida de um } \\
\text { UDV. }\end{array}$ \\
\hline $\begin{array}{l}\text { João não tinha ideia que um UDV tinha } \\
\text { interesse em navegar na internet. Após o } \\
\text { teste, ele teve ciência dessa realidade e } \\
\text { percebeu que os sistemas devem ser } \\
\text { acessíveis a todos. Ele acredita que o fato } \\
\text { do sítio ser acessível não influenciaria } \\
\text { negativamente para ele, mas para um } \\
\text { deficiente visual seria a forma de ele ter } \\
\text { acesso à informação. }\end{array}$ \\
\hline
\end{tabular} \mid

\subsection{Resultados alcançados durante os pré-testes com os UDV do CEED.}

Esse pré-teste foi totalmente voluntário, sem fins lucrativos conforme o TCLE, termo previamente citado e assinado por todos os usuários. Após o pré-teste o usuário era convidado a responder um questionário com duas etapas. A primeira etapa destinava-se aos dados pessoais do entrevistado. A segunda etapa é destinada a perguntas sobre o pré-teste. São questões que avaliam a acessibilidade, o manuseio, a compreensão e a tecnologia utilizada no sítio durante a navegação, sendo ela móvel ou não, além do acesso às informações.

Essas informações são importantes para que a interface a ser desenvolvida não possua os mesmos erros que incomodaram a maioria dos voluntários. A última questão foi aberta para que os usuários pudessem dar suas opiniões, sugestões e reclamações a respeito das dificuldades que apareceram no decorrer do pré-teste e relatarem, caso necessário, o que sentiram. 
A partir da análise dos dados dessas questões pôde-se entender: (a) o grau de acessibilidade do sítio analisado, (b) quais os problemas que mais o incomodam, (c) as maiores dificuldades que tiveram ao tentar acessar as informações e (d) seu sentimento a respeito da experiência, sem direcionar o usuário a alguma resposta.

Após a análise dos dados foi feito um mapa dos perfis etários, sociais e emocionais, tanto de aceitação quanto de repúdio, para criar uma persona que melhor represente esse público não se esquecendo do design emocional. Dessa maneira, Mariana Cordeiro é a persona final que melhor representa os UDV e está descrita na Tabela 4-6 - Persona Mariana, UDV total.

\subsubsection{Observações e considerações dos alunos na entrevista, questões multiobjetivas:}

Realizado nas dependências no CEEDV, com autorização escrita e assinada pela direção da escola, o pré-teste teve duração de dois meses e colaboração de homens e mulheres com deficiência visual total ou parcial, conforme o Gráfico - 4-1. Os usuários tinham faixa etária entre 18 a 70 anos sendo que a maior concentração de pessoas estava nas idades entre 25 a 40 anos como mostra o Gráfico - 4-2. A média das idades ficou em torno dos 32 anos.

OBS: Dos $62 \%$ dos usuários que possui deficiência visual total, a preferência de leitor de tela é o software pago JAWS, porém, alguns usuários utilizam o NVDA por não possuírem a licença. Dos usuários que fizeram o pré-teste com o auxilio do computador com deficiência visual total, todos utilizavam o sistema operacional Windows 7 em suas residências por ser compatível com o leitor de tela utilizado. Dos $38 \%$ dos UDV parcial, somente os que precisavam do auxilio do leitor de tela utilizaram a versão do Windows 7, os demais, utilizaram o Windows 8. Nenhuns dos participantes utilizaram o sistema operacional Linux. 


\section{Grau de Deficiencia}

घ1 - Deficiência Total $\square 2$ - Deficiência Parcial

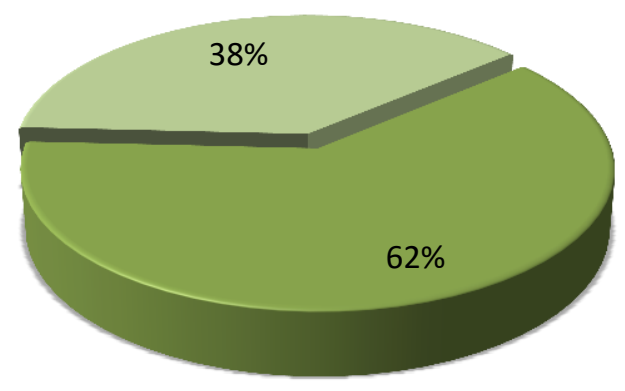

Gráfico - 4-1 - Porcentagem de UDV totais ou parciais que participaram dos pré-testes do CEEDV.

\section{Média das idades}

$\square 18-20 \square 20-25 \square 25-30 \square 30-40 \square 40-70$

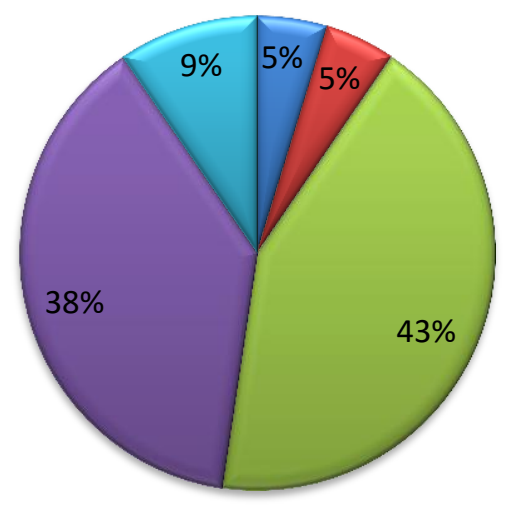

Gráfico - 4-2 - Distribuição das idades dos deficientes visuais do CEEDV

O público alvo do pré-teste foram os voluntários que frequentam a escola: (a) estudantes, (b) usuários que usam o espaço da escola para conviver com outros deficientes visuais, (c) usuários que utilizam os recursos dos "voluntários leitores", pessoas que disponibilizam seu tempo de forma gratuita e voluntária para ler para os PDV ajudando no estudo das matérias do ensino médio e para concurso.

Para que o teste fosse aplicado, foi necessário que o voluntário tivesse o mínimo de conhecimento no uso do computador ou que estivesse usando o seu celular para acessar a internet a mais de três meses, tempo médio que um usuário com deficiência visual leva para aprender e manusear o aparelho ${ }^{12}$. O Gráfico - 4-3 mostra o percentual de acesso à Internet durante o mês.

12 Informação adquirida a partir de entrevista com os usuários do CEEDV. Antes do começo dos prétestes os usuários relataram que, em média, o aprendizado para manusear o celular é de aproximadamente três meses. 


\section{Frequência do uso do computador/dispositivos móveis para navegar na internet}

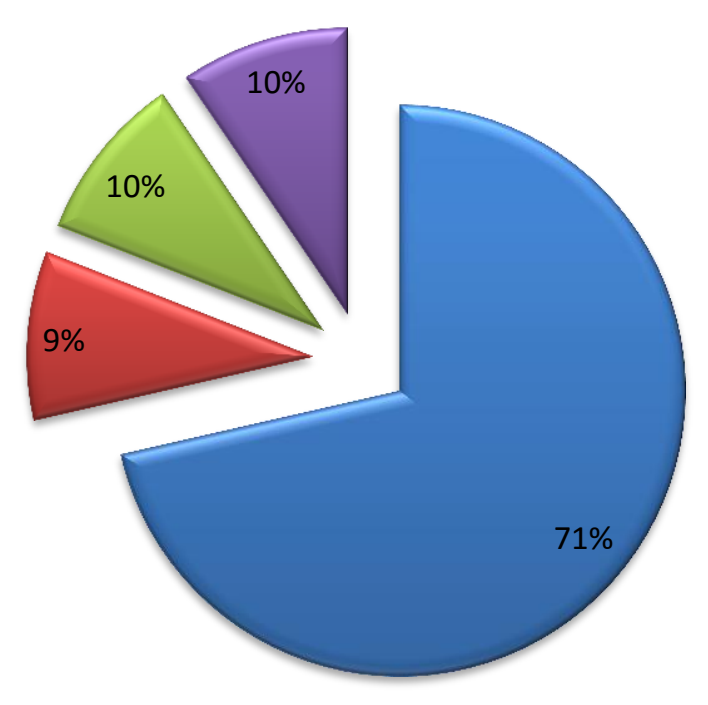

$\square 1$ - Diariamente

$\nabla 2$ - Ocasionalmente

$\square 3$ - Algumas vezes por semana

$\square 4$ - Algumas vezes por mês

Gráfico - 4-3 - Frequência do uso da internet

Foi questionado aos usuários qual seria na opinião deles, o nível de conhecimento que acreditavam ter no manuseio do computador/dispositivos móveis. Isso foi necessário para que pudessem relacionar os dados da frequência no uso da internet, conhecimento do mecanismo que utiliza a internet e o quantitativo de pessoas que conseguiam terminar o pré-teste. Segundo os dados obtidos, $48 \%$ dos usuários acham fácil manusear o computador e desses, $67 \%$ consegue compreender bem as estruturas dos sítios visitados. Os $29 \%$ dos usuários que responderam que acham difícil ou muito difícil manusear o computador preferem acessar exclusivamente a internet por meio de seus dispositivos móveis, essas informações estão dispostas nos Gráfico - 4-4 e Gráfico - 4-5. 
Conhecimento no uso do computador.

घ1 - Fácil

घ2 - Muito fácil

$\square 3$ - Nem fácil nem difícil

$\square 4$ - Difícil

$\square 5$ - Muito difícil
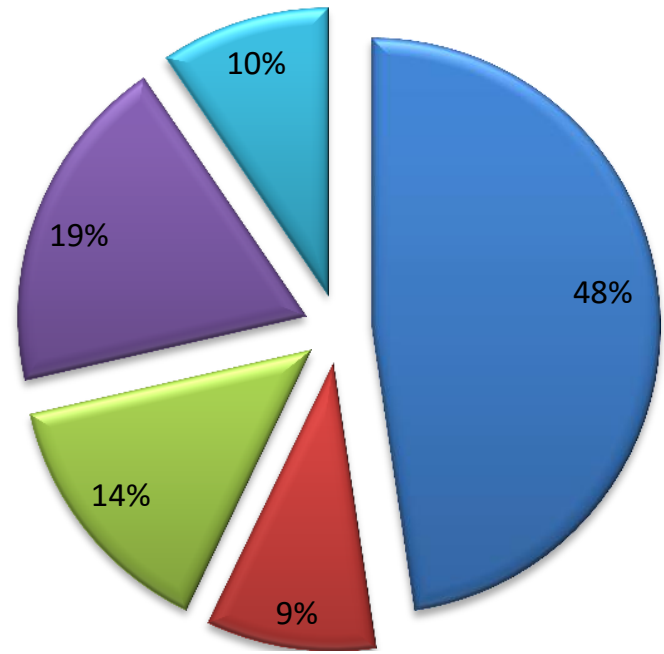

Gráfico - 4-4 - Nível de Conhecimento no uso do computador/dispositivos móveis.

\section{Compreensão das estrutuas dos sítios.}

घ1 - Fácil

甲2 - Muito fácil

『3 - Nem fácil nem difícil

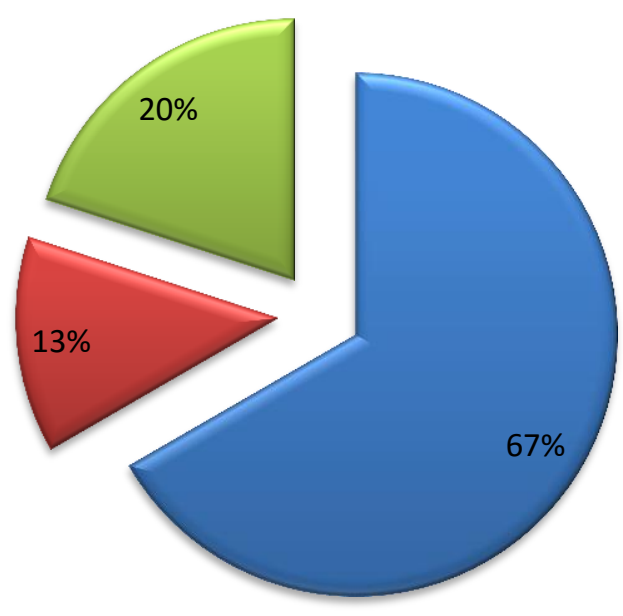

Gráfico - 4-5 Conhecimento relativo do uso do computador/dispositivos móveis pelo usuário.

Após apresentação da proposta do trabalho começaram os pré-testes. Primeiro foram realizados os pré-testes com o uso do computador. Conforme o usuário se sentia mais confortável individualmente ou coletivamente, ele era convidado a seguir os passos descritos na Tabela 3-5. Ao término dessa etapa começaram os pré-testes com o uso do celular.

A quantidade de PDV totais que trabalham é praticamente igual à quantidade de UDV total que não trabalham, porém quando se trata de deficiência parcial a quantidade de pessoas que não trabalham chega a $82 \%$ como mostra o Gráfico - 4-6. O fato do usuário não trabalhar não é empecilho para que ele tenha acesso à internet como mostra o Gráfico - 4-7. 


\section{Deficiência Total}

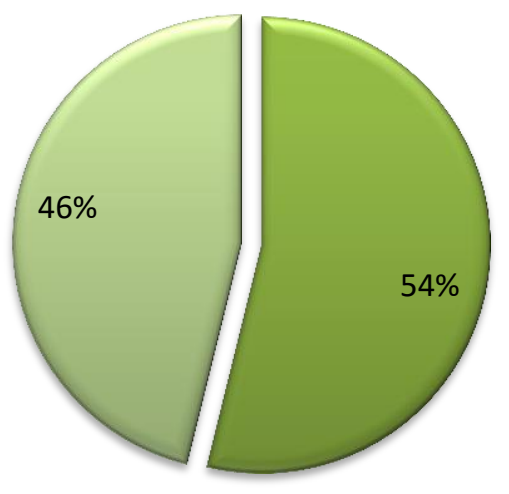

Deficiência Parcial

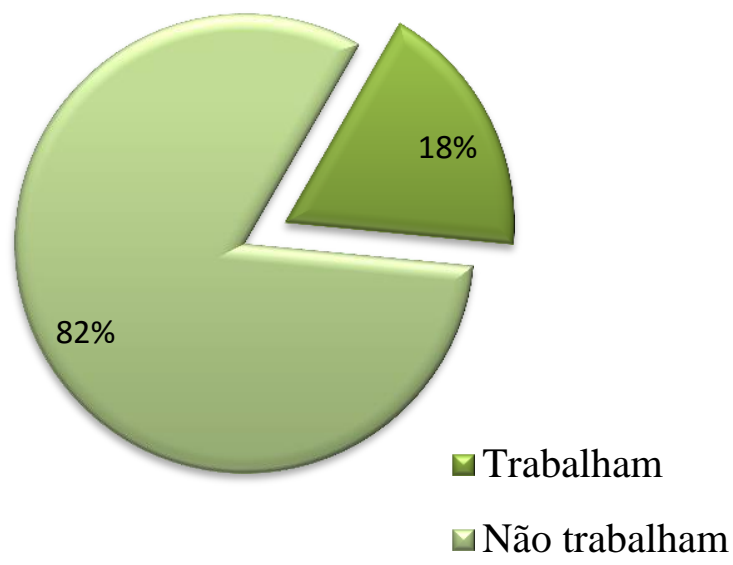

Gráfico - 4-6 - Porcentagem de deficientes que trabalham.

\section{Trabalho X Uso da Internet}

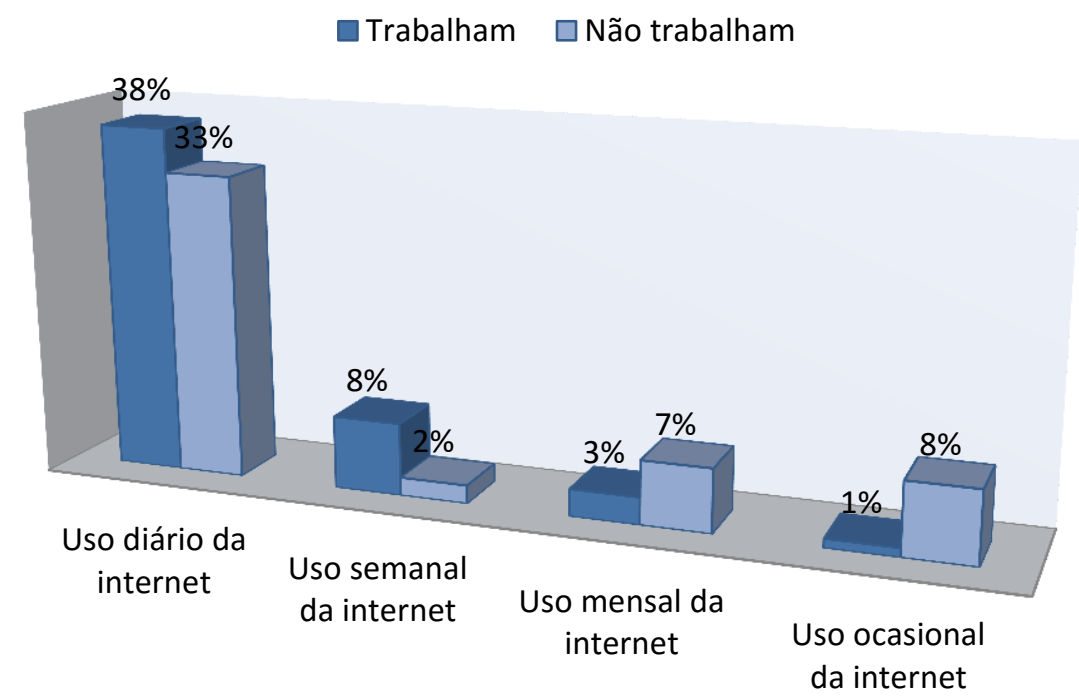

Gráfico - 4-7 - Frequência do uso da internet

A quantidade de UDV que trabalha e possui casa própria é $10 \%$ maior que a quantidade de pessoas que não trabalha e possui casa própria, isso se deve aos programas assistenciais do Governo do Distrito Federal - GDF que no projeto de lei no 3.298/99, prevê a distribuição de casas e apartamentos populares a muitos deficientes. A relação de usuários que trabalham e possuem uma moradia própria pode ser observada no Gráfico - 4-8. 


\section{Trabalho X Moradia}

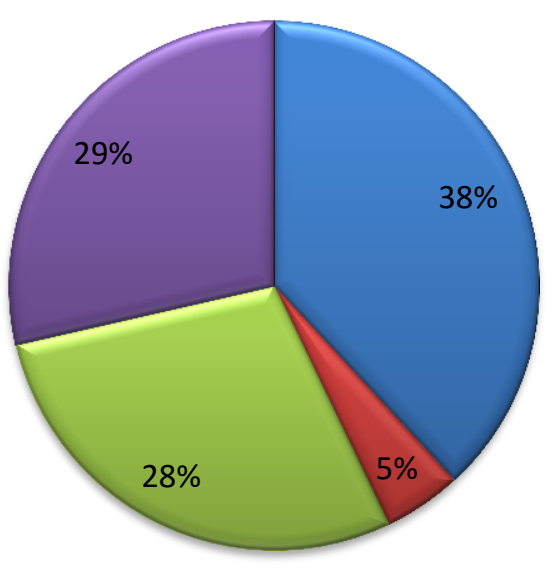

$\square$ Trabalham e possuem casa própria

๑ Trabalham e não possuem casa própria

$\square$ Não trabalham e possuem casa própria

曰 Não trabalham e não possuem casa própria

Gráfico - 4-8 - Relação de trabalho e Casa própria

A quantidade de UDV que possui acessibilidade em casa é maior que a quantidade de usuários que possuem acessibilidade no apartamento, não importando se a residência é própria ou alugada, porém os que moram em apartamento possuem acessibilidade no prédio, como pode ser visto na Figura 4-2.

OBS.: Nenhum usuário da amostra que mora em apartamento possui acessibilidade dentro da unidade somente no prédio.

\section{Acessibilidade Residencial}

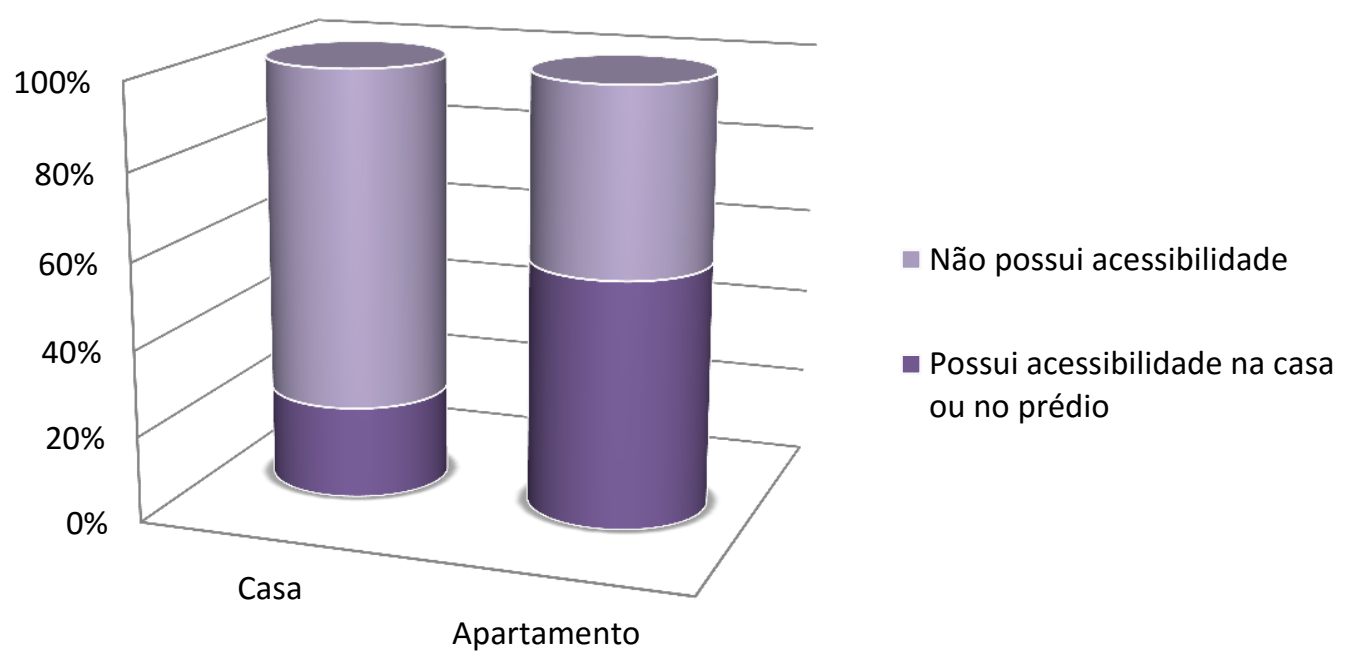

Figura 4-2 - Acessibilidade residencial

A quantidade de UDV que moram com outras pessoas é $86 \%$ e $52 \%$ moram com outros deficientes visuais. Para maior detalhamento entre a relação dos deficientes que: (a) 
trabalham ou não, (b) tem casa própria, (c) moram com outros deficientes visuais e (d) conseguiram ou não finalizar a tarefa pode-se consultar o Gráfico - 4-9.

Tabela 4-5 - Tabela quantitativo de pessoas que moram com outros deficientes visuais

\begin{tabular}{|l|l|}
\hline Número de residentes em casa & Existe mais de uma pessoa deficiente visual? \\
\hline - $86 \%$ dos usuários pesquisados moram & $\bullet \quad 52 \%$ dos usuários pesquisados moram com \\
$\begin{array}{l}\text { com } 2 \text { a } 5 \text { pessoas na mesma casa. } \\
\text { - } \begin{array}{l}\text { outros deficientes visuais. } \\
\text { com mais de } 5 \text { pessoas na mesma } \\
\text { casa. }\end{array}\end{array}$ & \begin{tabular}{l} 
com outros deficientes visuais. \\
\hline
\end{tabular}
\end{tabular}

\section{Relação entre: \\ Trabalho X Moradia X Término da tarefa}

$\square$ Deficiência Total-Trabalham-Casa própria-Mora com mais de uma pessoa Deficente Visual-Terminou a tarefa

घDeficiência Total-Não trabalham-Casa própria-Mora com mais de uma pessoa Deficente Visual-Terminou a tarefa

$\square$ Deficiência Total-Não trabalham-Casa própria-Mora com mais de uma pessoa Deficente Visual-Não terminou a tarefa

- Deficiência Parcial-Trabalham-Casa própria-Mora com mais de uma pessoa Deficente Visual-Terminou a tarefa

—Deficiência Parcial-Não trabalham-Casa própria-Mora com mais de uma pessoa Deficente Visual-Terminou a tarefa

$\square$ Restante

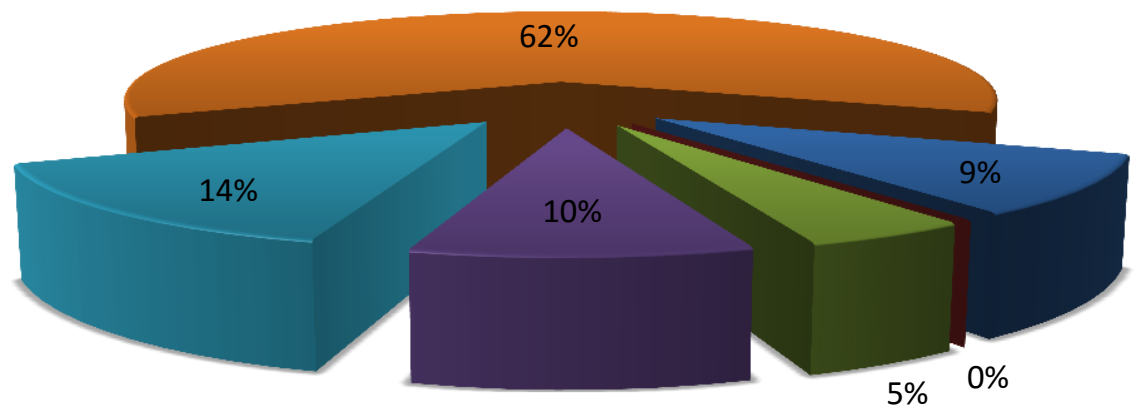

Gráfico - 4-9- Gráfico resumo 


\subsubsection{Observações e considerações dos alunos na entrevista, questões objetivas:}

Durante o teste, o pesquisador ficou em observação a fim de conhecer a rotina e os caminhos que o usuário percorria para executar as ações requisitadas. Com a finalidade de se obter informações suficientes para a criação da interface que melhor atenderia esse público por isso foi necessário escutar as considerações dos próprios usuários. Todas as informações obtidas nessa etapa ajudaram na construção da persona de apoio para criação da interface.

1) Segundo a avaliação de desempenho dos próprios usuários ao final do pré-teste, os dados obtidos geram o gráfíco Gráfico - 4-10 que mostra que 67\% conseguiram realizar as tarefas requeridas.

OBS: Nenhum usuário costuma acessar o sítio sugerido, por achá-lo sem acessibilidade e preferindo utilizar o navegador pelo computador. $67 \%$ dos usuários preferem utilizar o aplicativo do sítio, 33\% tiveram problemas com a acessibilidade do celular e desses, $20 \%$ não se interessa pelo conteúdo e $10 \%$ optaram seguir a página pelo Faceboock.

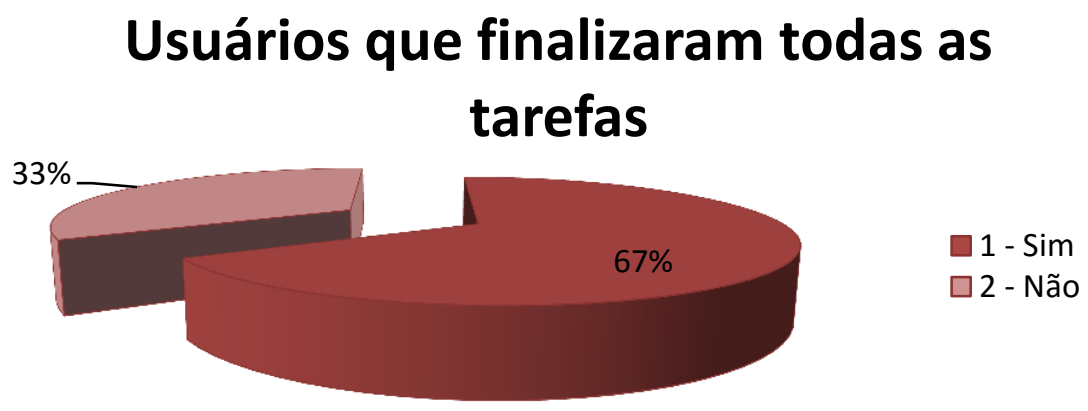

Gráfico - 4-10 - Usuários que conseguiram finalizar a tarefa.

Os temas com maior queixa entre os voluntários foram:

1) As imagens e os ícones:

- Falta de descrição, de legendas, de ícones e de imagens.

- As imagens não ampliam.

2) Uso do comando de voz:

- Fazem pesquisas ou realizam ações por meio do comando de voz; 
- Preferem usar o celular pelo conforto e comodidade que o comando de voz traz.

3) Excesso e desorganização de links dificultam a navegação:

- O uso de um sinal sonoro que avise sobre a abertura de um link;

- Os nomes dos links deveriam ser mais intuitivos;

- Maior espaçamento entre os links para que não fosse acessado mais de um simultaneamente.

4) Áudio-descrição e legendas nos vídeos:

- Falta de descrição dos ícones na barra de navegação do vídeo;

- O excesso de propagandas e links automáticos em todo o sítio, principalmente na área do vídeo;

- $\quad$ O fato do leitor não poder ler as legendas quando em outro idioma;

- Legendas brancas ou pretas de acordo com o fundo da imagem ajuda o deficiente com baixa visão na questão do contraste.

5) Touch screen:

- O uso do toutch screen quando é utilizado com leitor de tela que acompanhe a velocidade do toque ajuda muito o usuário com deficiência visual. Muitos preferem encontrar os aplicativos pela localização na tela ao utilizar o comando de voz;

- Os sítios que mantêm a resolução quando ampliados pelo toutch screen ajudam o usuário na visualização.

6) Estilo da fonte:

- Usuários com deficiência parcial reclamam da falta de contraste nos sítios.

- Uso das letras nas cores: vermelho, amarelo, azul, sem que haja a opção de acessibilidade para a mudança.

- Letras pequenas e com fontes de difícil entendimento, sem que haja a opção de acessibilidade para a mudança.

7) Excesso de atualizações nas páginas retarda o processo de leitura da tela e confundem o entendimento. 
8) Menus e caixas de marcação combinadas e de difícil acesso.

Para um aplicativo mais acessível, além desses temas já abordados, os usuários recorreram também a:

9) Manual de instruções do próprio aplicativo.

10) Descriçõos sucintas e direcionais.

\subsubsection{Principais considerações observadas pelo pesquisador:}

1) Durante o pré-teste os usuários sentiram medo de errar. O erro fazia com que pensassem em desistir sem querer tentar novamente.

2) A reclamação de falta de acessibilidade era unânime. O maior sentimento era de descaso e de injustiça. A frustação ocorria quando uma tarefa fácil se tornava difícil pelo uso do dispositivo que estava sendo utilizado. Para os que utilizaram o computador a frustação era de saber que com o uso do celular aquela tarefa poderia ser feita em poucos passos e que no aplicativo do sítio em questão não haveria tamanhas dificuldades. Para os que utilizavam o celular, a frustação ocorria em saber que o uso do leitor de tela facilitaria a tarefa e as teclas de atalho seriam um apoio em um sítio tabular.

3) Quando solicitado, a tarefa de "encontrar uma matéria específica requerida pela pesquisadora, utilizando o buscador do sítio." houve frustação, indignação e desconforto, muitos usuários se sentiram menosprezados. Os usuários reclamaram da falta das normatizações da W3C.

Após as observações feitas pelos usuários e pela pesquisadora durante e após o préteste, foi possível criar uma persona que aglutina as características mais relevantes. Mariana Cordeiro foi o nome dado à persona criada para facilitar a elaboração do melhor método para interfaces acessíveis que visam atender aos usuários com e sem deficiência visual.

\subsubsection{Descrição da persona Mariana baseada nos pré-testes realizados no CEEDV}

Com base nas entrevistas, observações e pré-testes executados no método adoptado foi possível detalhar o perfil do usuário, suas dificuldades e facilidades diante das situações teste estabelecidas. A partir da análise das respostas obtidas, puderam-se unificar as informações e elaborar um personagem em um documento detalhado na Tabela 45. 
A Tabela 4-6 detalha a persona Mariana Cordeiro por gravura e descrição. Gerada de acordo com os pré-testes realizados, a tabela está dividida em duas colunas, o lado esquerdo com a ilustração da persona com deficiência visual total, e do lado direito com a descrição que define a persona criada. Para a criação de Maria foi levado em consideração todos os usuários que realizaram o pré-teste no CEEDV.

Tabela 4-6 - Persona Mariana, UDV total.

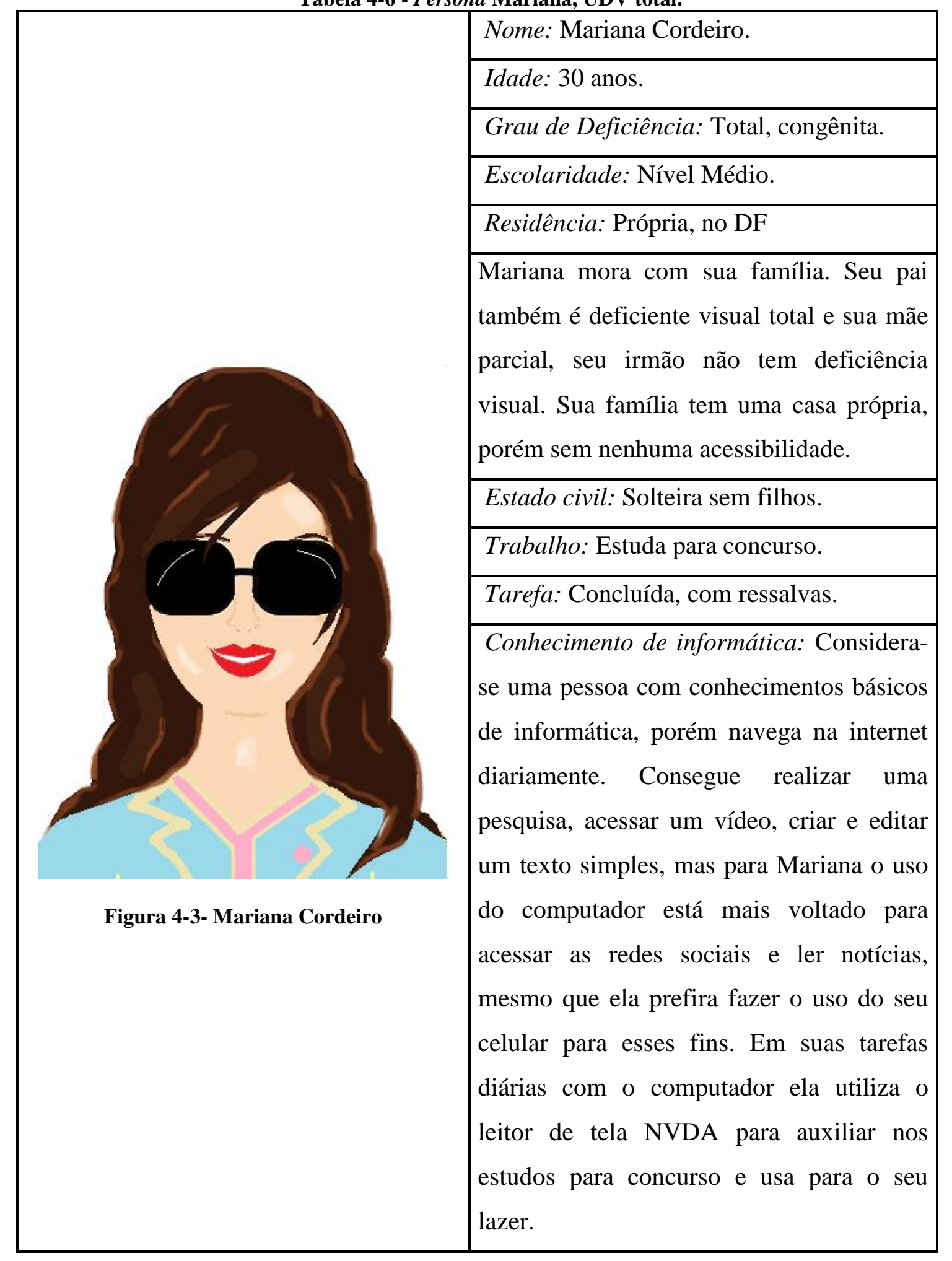


Perfil: Mariana se considera uma pessoa comunicativa, porém se sente meio inibida quando tem que trabalhar com computadores em razão das suas dificuldades em exercer algumas funções. Ela diz que a grande maioria dos sítios que ela tenta acessar pelo computador não tem acessibilidade. Sua maior queixa é a falta de descrição das imagens, botões e ícones o uso de sítios tabulares, o excesso de caixas suspensas. Prefere o uso do celular para realizar algumas ações. Utiliza um software livre de leitor de tela chamado NVDA, para sua acessibilidade no computador. Para o uso do seu celular ou tablet ela utiliza os recursos de acessibilidade de seu celular. Utilizando seu celular Android a cerca de um ano, ela teve dificuldades no princípio, porém depois de quatro (4) meses, ela já conseguia fazer a maioria das coisas necessárias no celular.

Mariana utiliza muito o comando de voz e relatou que para o uso das páginas de internet ela prefere o computador, apesar de a legislação e de as diretrizes aconselharem que haja sítios acessíveis a todos e isso não ocorra ainda. $\mathrm{O}$ uso do celular é a escolha quando os sítios esses possuem aplicativos próprios ou aplicativos que geram acessibilidade em seu dia-a-dia como, por exemplo, o aplicativo para ler dinheiro. 


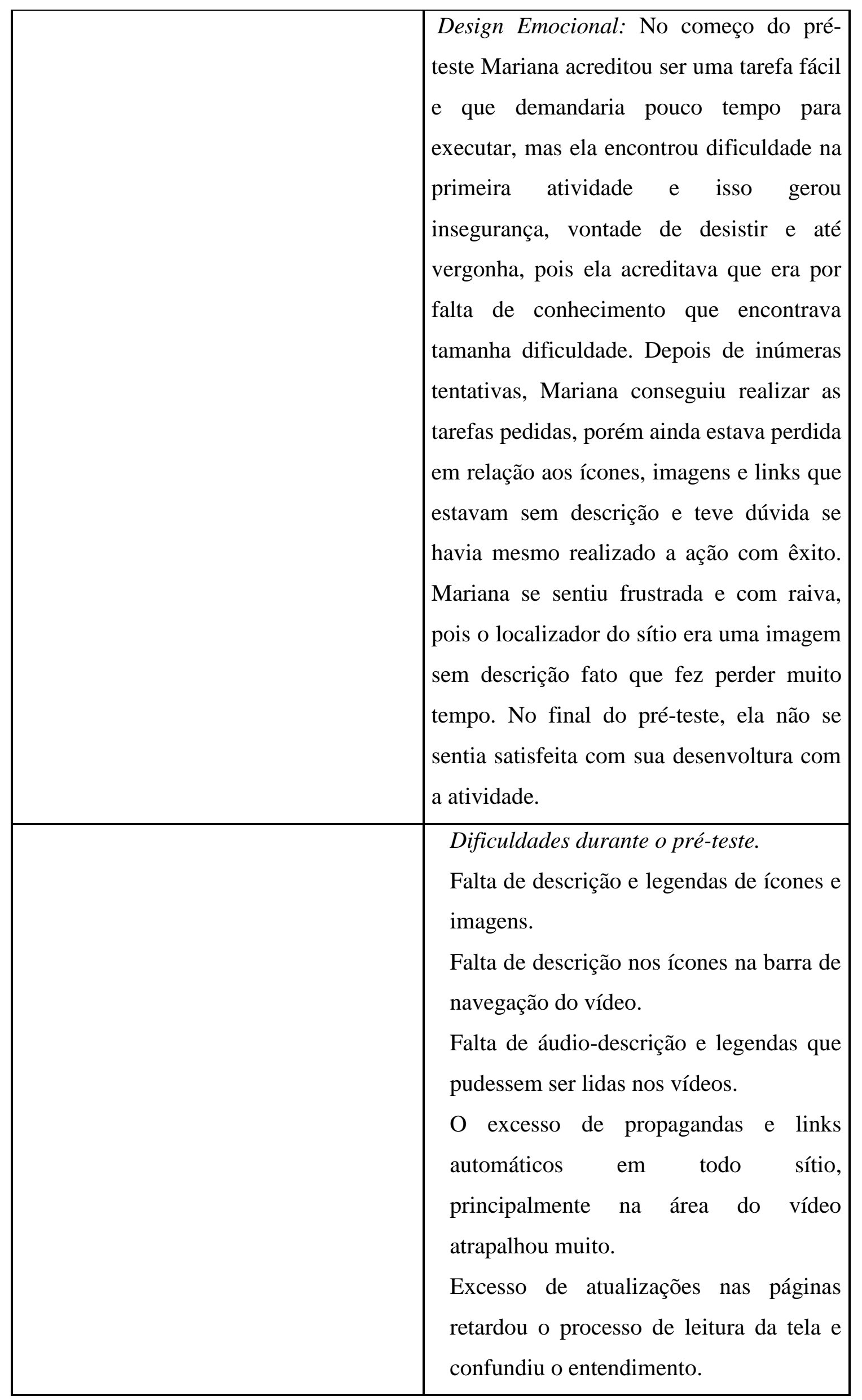




\begin{tabular}{|l|l|}
\hline Menus e caixas de marcação combinadas \\
e de difícil acesso. \\
Falta do comando de voz para fazer \\
pesquisas ou realizar ações. \\
Uso em excesso e desorganizado de links \\
dificultam a navegação. \\
O uso de um sinal sonoro que avisasse \\
que o link abriu ajudaria. Sentiu-se \\
perdida. \\
\hline $\begin{array}{l}\text { Mariana não encontra com facilidade } \\
\text { sítios com acessibilidade, mas os recursos } \\
\text { de acessibilidade do W3C a ajuda ser } \\
\text { incluída neste mundo tecnológico. Ao } \\
\text { responder ao questionário relata que a falta } \\
\text { de acessibilidade faz que ela procure outros } \\
\text { meios de adquirir a mesma informação. }\end{array}$ \\
\hline
\end{tabular}

A fim de atender as perspectivas das personas sem deficiência visual o layout foi ajustado. As figura 4-4 e figura 4-5 mostram as telas de menu de opções e a tela de configurações atendendo aos padrões da W3C e as considerações dos usuários sem interferir no layout.

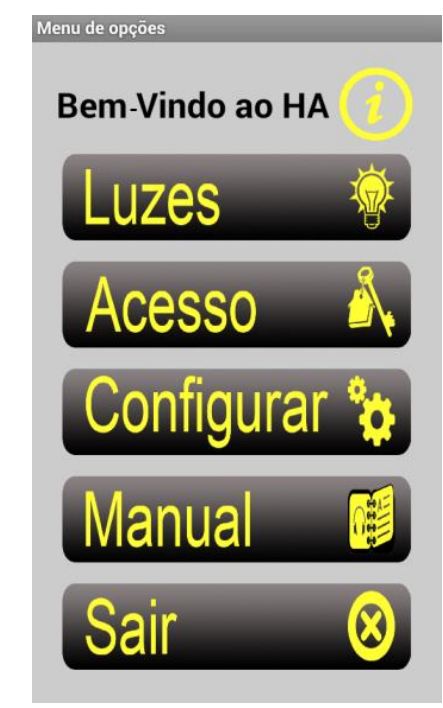

Figura 4-4 - Tela principal - Menu opções

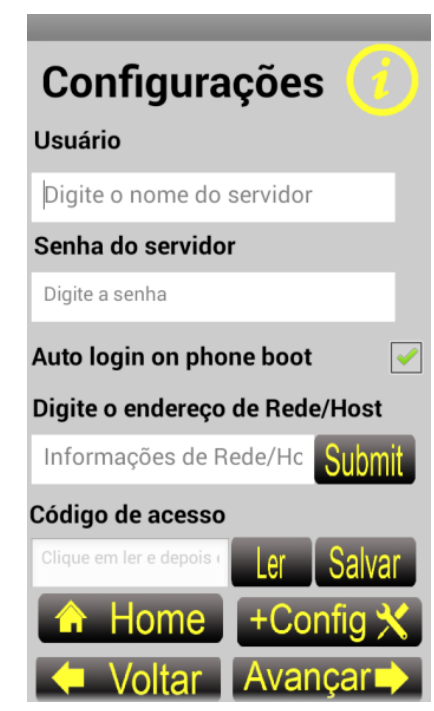

Figura 4-5 - Tela de configurações 


\subsection{Fase de teste do aplicativo desenvolvido para atender às personas João da Silva e} Mariana Cordeiro.

Com o propósito de testar o método aplicado na criação da interface acessível para UDV e controlar sua residência por meio de dispositivo móvel, foi criado um protótipo composto por uma casa, figura 4-8, figura 4-9 e figura 4-10 composta por quatro lâmpadas de led e um portão, figura 4-6 e figura 4-7. Para que o portão abrisse e fechasse sem a necessidade de acionar um segundo comando, foi inserido um circuito de eletrônica de potência do tipo chopper denominado ponte $H$ na central de automação. Assim, os usuários puderam testar suas considerações sobre a acessibilidade do aplicativo $H A$. O protótipo final pode ser visto na figura 4-12.

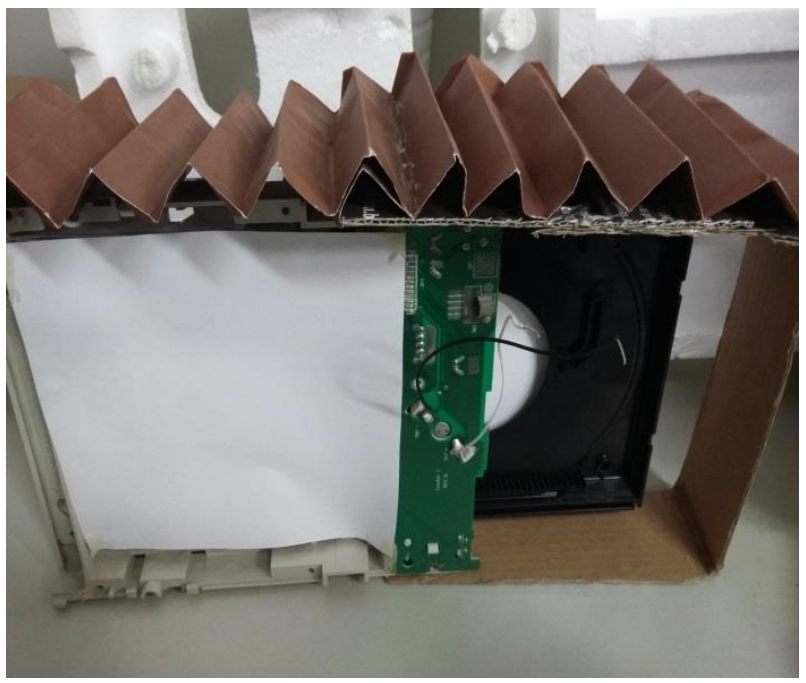

Figura 4-6 - Protótipo do portão por trás.

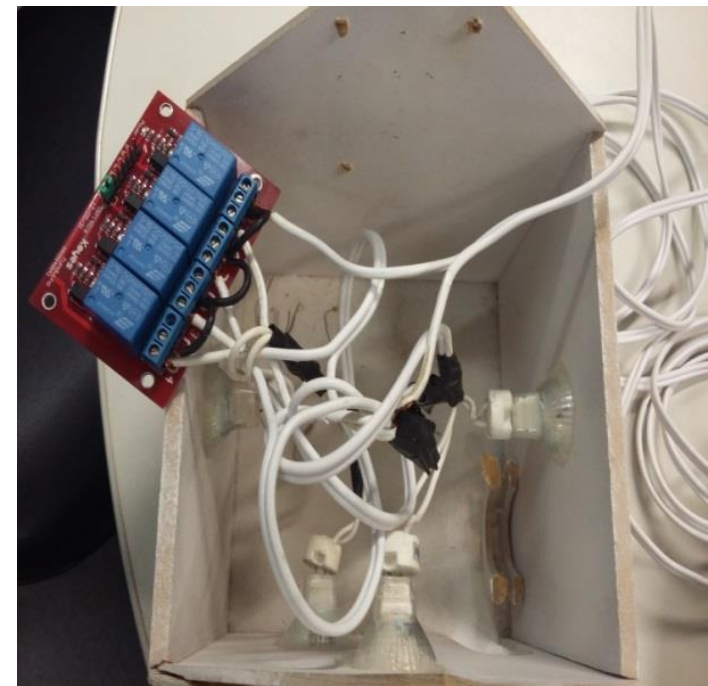

Figura 4-8 - Vista superior do protótipo - Casa composta por uma placa com 4 relés

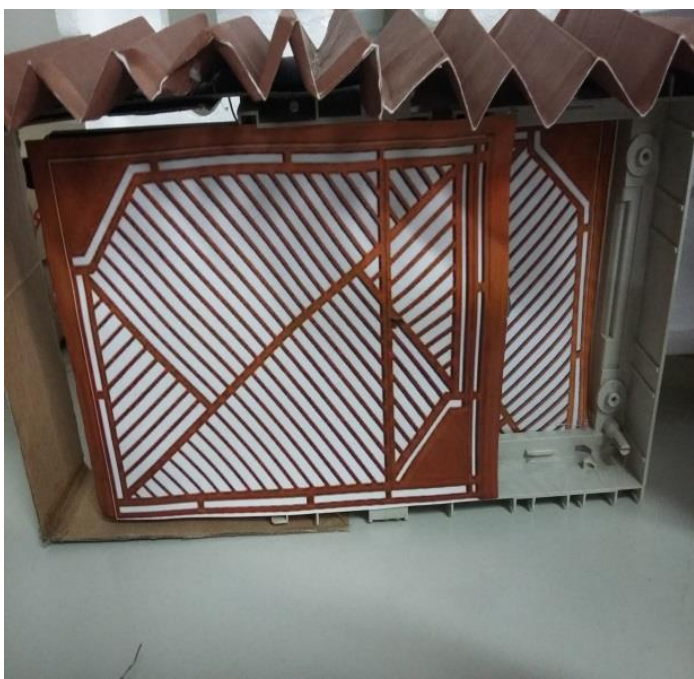

Figura 4-7 - Protótipo do portão pela frente.

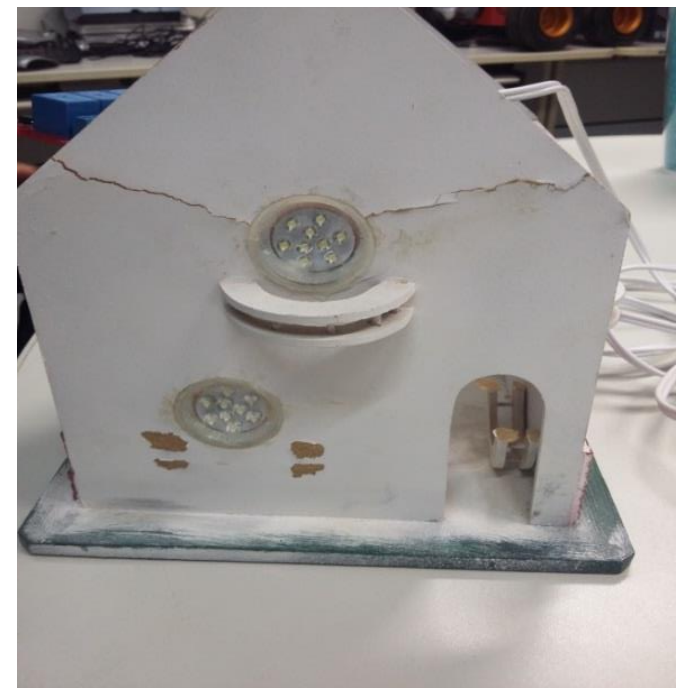

Figura 4-10 - Vista frontal do protótipo. Casa com 4 lâmpadas de led, sendo duas na parte frontal 


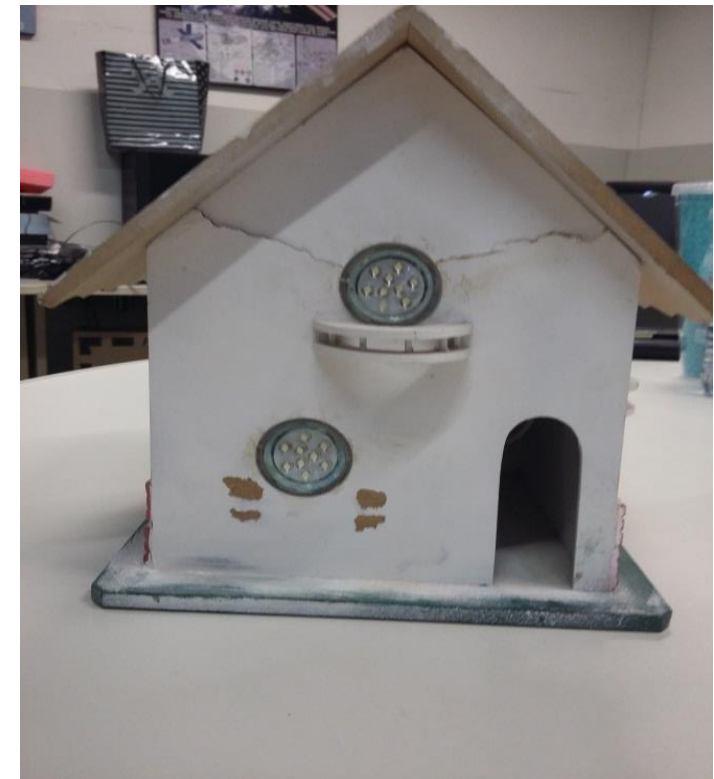

Figura 4-9 - Protótipo da casa, pré-montado.

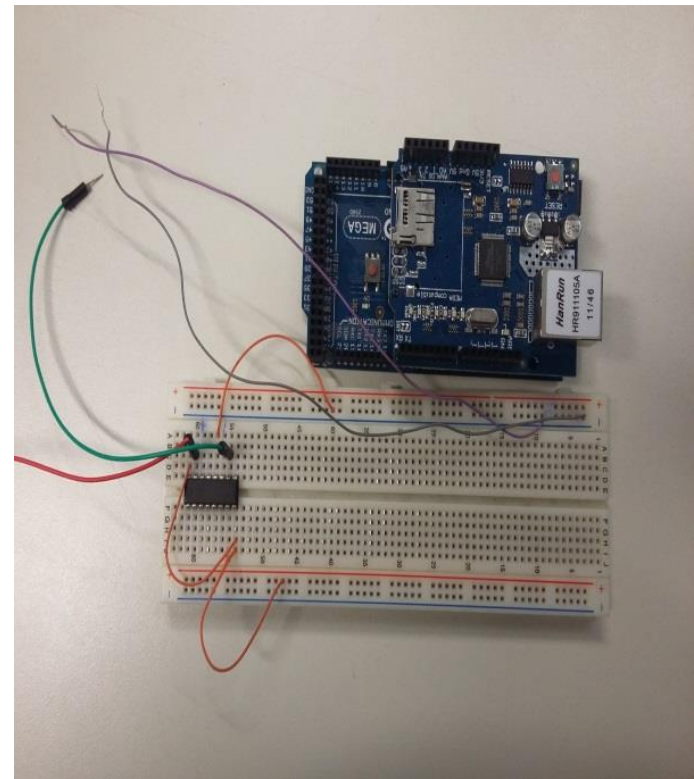

Figura 4-11- Central de automação composta por Arduino MEGA e Shield ETHERNET.

PS: As lâmpadas representam todos os atuadores que podem ser inseridos na residência e o portão todos os sensores.

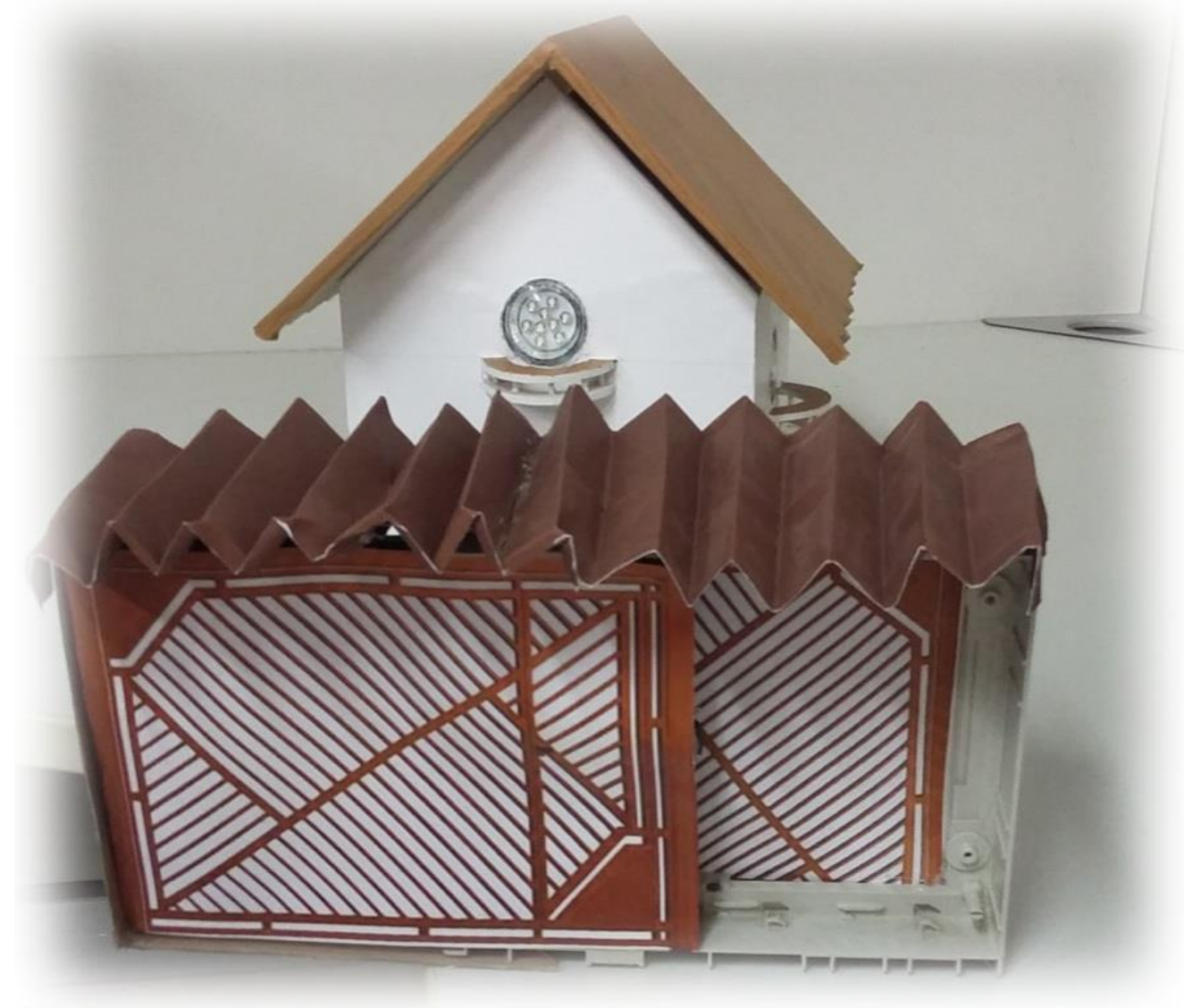

Figura 4-12 - Protótipo final 


\subsection{Testes com os usuários}

De forma a validar o método aplicado na criação da interface acessível para UDV controlarem sua residência por meio de dispositivo móvel, foram realizados, nas dependências da Universidade de Brasília, sob a supervisão do professor Carlos Llanos, testes com três deficientes visuais totais e três usuários sem deficiência.

O teste foi composto pelos seguintes passos:

1. Fazer o download do aplicativo.spk no dispositivo móvel do usuário e instalar.

2. Encontrar e abrir o aplicativo na área de trabalho.

3. Descrever a tela de início.

4. Acessar o botão de informações da página.

5. Acessar o menu controle de luzes na tela de início e ligar uma ou mais luzes. Podendo ligar pelo botão "ligar" ou pelo "comando por voz."

6. Navegar pelas teclas de navegação "voltar", "avançar" e "home".

7. Acessar o menu acesso ao portão na tela de início e acionar pelo cartão ou por "comando por voz" o portão.

8. Acessar o menu manual na tela de início e verificar a acessibilidade.

Após execução dos passos acima, o usuário foi convidado a relatar suas dificuldades e sugestões para melhorar a interface do aplicativo.

Segundo avaliação dos usuários, o aplicativo atende as normas e diretrizes do W3C de acessibilidade. A Tabela 4-7 relata, de forma sucinta, as principais avalições do usuário.

Tabela 4-7 - Avaliação do HA

\begin{tabular}{|c|c|c|c|c|c|}
\hline & $\begin{array}{c}\text { Gostou da } \\
\text { Interface } \\
\text { sugerida. }\end{array}$ & $\begin{array}{c}\text { Tevestão } \\
\text { para } \\
\text { melhorar a o } \\
\text { SA HA. }\end{array}$ & $\begin{array}{c}\text { Teve alguma } \\
\text { sugestão para } \\
\text { melhorar a } \\
\text { Interface do } \\
\text { HA. }\end{array}$ & $\begin{array}{c}\text { Usaria o } \\
\text { aplicativo. }\end{array}$ & $\begin{array}{c}\text { Conseguiu } \\
\text { acionar e } \\
\text { controlar os } \\
\text { dispositivos } \\
\text { requeridos. }\end{array}$ \\
\hline $\begin{array}{c}\text { Usuários com } \\
\text { deficiência }\end{array}$ & $\mathrm{x}$ & $\mathrm{x}$ & $\mathrm{X}^{*}$ & $\mathrm{x}$ & $\mathrm{x}$ \\
\hline $\begin{array}{c}\text { Usuários sem } \\
\text { deficiência }\end{array}$ & & & & $\mathrm{x}$ & $\mathrm{x}$ \\
\hline
\end{tabular}

PS * A única tela do aplicativo que teve considerações sobre melhoria foi a de "controle de luzes". Os usuários questionaram sobre a disposição dos itens na tela. 


\subsection{Conclusões do Capítulo}

Esse capítulo apresentou os resultados alcançados pelo método apresentado no capítulo 3. Foram detalhados em forma de gráficos, tabelas e figuras o perfil dos usuários que participaram dos pré-testes realizados nas dependências da UnB e do CEEDV.

Foram mostrados os percentuais das questões mais relevantes para o conhecimento e entendimento do perfil do usuário. Dessa forma, foi levado em consideração o design emocional, as dificuldades e sensações durante o pré-teste bem como questões relativas ao seu cotidiano. Ao final, foram coletados e analisados os dados que levaram a criação das personas. A partir dessas análises, foi descrito com riqueza de detalhes os perfis: João da Silva e Mariana Cordeiro que auxiliaram no desenvolvimento da interface modelo de acessibilidade.

O método proposto visou sanar as principais queixas dos usuários, além de satisfazer às suas expectativas quando se trata de interfaces para dispositivos móveis. A interface modelo de acessibilidade atenderá João da Silva e Mariana Cordeiro simultaneamente.

Para validar o modelo de interface, verificar se esse satisfaz, de fato, as expectativas das personas. Para isso, foi realizado um teste com usuários. Por isso, foi possível comprovar que para esse caso a interface atende aos parâmetros tanto do João da Silva quanto da Mariana Cordeiro. 


\section{CONCLUSÕES E TRABALHOS FUTUROS}

Com o método utilizado foi possível criar uma interface homem-máquina que melhora os quesitos de acessibilidade de usuários com deficiência visual na área da domótica. Aspectos como comunicação na domótica e design universal, necessários para o desenvolvimento da interface para usuários com deficiência visual, com usabilidade e fator emocional, foram abordados no capítulo 2 (dois).

Para identificar as necessidades do usuário foi realizado pré-testes, questionários e observação com os usuários do CEEDV e alunos na Universidade de Brasília. Para a realização dos pré-testes, foi utilizado o capítulo 3 (três) para calcular o tamanho da amostra assim como analise e delimitado o espaço amostral. O modelo de automação residencial orientado a usuários com deficiência visual a ser utilizado foi definido no mesmo capítulo.

Após a implantação da interface foi preciso validar junto ao usuário se esta atendia aos quesitos de acessibilidade no contexto domótico. Para isto foi realizado testes com usuários com e sem deficiência visual. Este teste foi abordado no capítulo 4 (quatro).

\subsection{Conclusões parciais - Alunos UnB.}

\subsubsection{Pré-testes com os alunos da Universidade de Brasília - UNB}

Durante o pré-teste com os alunos da Universidade de Brasília, foi identificado por meio da pesquisa falhas no processo de divulgação das leis que dispõem sobre o acesso à informação e à acessibilidade na WEB como um todo.

O termo acessibilidade ainda está vinculado a rampas, elevadores, botoeiras, entre outros. Muitas pessoas desconsideravam que os usuários deficientes poderiam ser potenciais usuários de sistemas informatizados. Além disso, as normatizações do W3C não tinham dimensões dos prejuízos causados pela falta de implantação de acessibilidade na WEB tanto para os UDV quanto para os demais deficientes. Nesse trabalho, o tema acessibilidade sai do âmbito das adaptações físicas e evolui para a acessibilidade informatizada.

Durante os pré-testes, foram utilizadas as técnicas de observação e entrevista, a falta de acessibilidade no sítio foi o fator que mais trouxe dificuldade aos alunos na realização das tarefas requisitadas. Com isso, ficou evidente que é preciso um trabalho de conscientização 
social, principalmente de gestores e desenvolvedores para que essas normatizações sejam incorporadas desde inicio aos projetos em seus sistemas.

Os pré-testes permitiram evidenciar que além dos UDV, outros usuários com deficiência se beneficiarão com a acessibilidade implantada nos sistemas. As pessoas com baixa visão são beneficiadas com o uso do contraste adequado. Pessoas com mobilidade reduzida ou que não possuem destreza com o uso do mouse, são beneficiadas quando criamos uma página que não tenha barreiras de acesso via teclado.

Outro fato que pôde ser observado durante os pré-testes é que mesmo que as teclas de atalho tenham sido criadas pela Apple em 1981, a grande maioria dos usuários desconhece e/ou não as usam. Durante o pré-teste, 95\% dos usuários desconheciam as teclas de atalho, fato que levou esses alunos a terem mais dificuldades em relação aos que conheciam.

Atualmente, com o poder computacional dos dispositivos móveis, os usuários estão migrando gradativamente dos computadores modelo desktop para tablet ou celular. Além de possuírem tecnologia toutch screen, essas telas sensíveis ao toque dispensam o uso de periféricos como mouse e teclados, fator que acaba contribuindo para que os usuários não utilizem os atalhos.

Os UDV aprendem todas as teclas de atalho necessárias para o uso do computador utilizando um leitor de tela como auxiliador. Com a frequência, esse uso torna-se natural. Ao simular pessoas que passaram por um trauma e estão com uma deficiência permanente ou temporária, ressalta-se essa diferença. A mesma dificuldade é observada no caso em que uma pessoa passa por um trauma e adquire uma deficiência permanente. É uma questão de readaptação, pois no início as dificuldades por já ter um conhecimento prévio dos periféricos aparecem, assim como no ocorrido com os alunos que realizaram o pré-teste tiveram. Porém, a falta de compatibilidade do sistema operacional com o leitor de tela e a falta de acessibilidade do sítio foram fatores que dificultam ainda mais a realização da atividade.

As teclas mais utilizadas pelos alunos foram o TAB, ENTER, ESC e o CTRL. O uso do mouse foi indispensável. Todos os usuários se queixaram por não poder usar o mouse nos cenários que não eram permitidos. Aos que utilizaram seus dispositivos móveis na realização das atividades, queixaram-se unanimemente de problemas com acessibilidade no sítio. 
$\mathrm{Na}$ realização da segunda tarefa ficou comprovado que o vídeo sugerido foi incompreendido pela ausência de legendas. Esse fato impede não somente que usuários surdos compreendam o conteúdo do vídeo, mas também que usuários com deficiência parcial, idosos com problemas auditivos ou visuais e até mesmo usuários que estão impossibilitados de utilizarem o som de seus computadores.

\subsubsection{Conclusões para o desenvolvimento da interface acessível - Alunos UnB.}

Após o pré-teste realizado nas dependências na UnB, pôde-se concluir que para o desenvolvimento de uma interface com acessibilidade é imprescindível que desde a fase de projeto já se tenha o cuidado de atender as diretrizes do $\mathrm{W} 3 \mathrm{C}$, principalmente no que diz respeito ao contraste, ao tamanho, ao estilo de fonte, às paletas de cores, às legendas, à resolução, à descrição das imagens e à disposição dos componentes na tela.

\subsection{Conclusões parciais - usuários do Centro de Ensino Especial de Deficientes Visuais - CEEDV}

\subsubsection{Pré-testes com os usuários do CEEDV}

Durante o pré-teste com os usuários do CEEDV, foi identificada uma mudança no perfil dos usuários deficientes visuais. Durante muito tempo, o acesso à Internet estava restrito somente aos computadores desktop. Com o advento dos dispositivos móveis, principalmente dos aparelhos tipo smartphones, esse meio de acesso vem sendo cada vez mais escolhido pelos UDV para se conectar ao mundo, pois se tornaram mais acessíveis economicamente.

Essa mudança não se deu somente pela facilidade na aquisição dos aparelhos, mas também pelo tempo de aprendizagem das funções básicas e essenciais nos dispositivos móveis ser relativamente curto, cerca de quatro meses, de acordo com os usuários entrevistados. Outras questões também se tornam atrativas. A principal delas é a função de acessibilidade que já está presente no aparelho e a inserção da função do toutch screen.

Questões como a possibilidade de estarem em contato com outras pessoas, a qualquer momento, por meio de mensagens de texto, de aplicativos que trazem acessibilidade para o dia-a-dia do usuário, tais como: leitor de dinheiro, leitor de cores e o foco do projeto (acessibilidade residencial), também são fatores decisivos para essa escolha. 
De acordo com os pré-testes pôde-se dividir o público em dois grandes grupos: (a) Os que possuem casa própria e trabalham, (b) os que não possuem casa própria e trabalham ambos independentemente se moram com mais deficientes ou não. Nesse caso, os demais usuários também podem ser contemplados dependendo da renda familiar.

Apesar do sistema de automação ser um sistema simples e de baixo custo, deve-se levar em consideração alguns fatores relevantes antes da sua implantação, tais como:

1. O princípio da acessibilidade com segurança deve ser priorizado em qualquer hipótese. Deve-se assegurar a segurança física do usuário, seus bens, seus valores, segurança psíquica, segurança do pleno funcionamento do sistema, software e hardwares envolvidos.

2. A necessidade do usuário deve ser priorizada. Antes de qualquer solução sugerida para o projeto é necessário entender as expectativas que o usuário possui em relação ao sistema. É necessário conhecer o usuário e suas reais necessidades antes de sugerir soluções. Neste método adotado o usuário é o centro do sistema de automação.

3. O sistema tem que estar projetado para atender aos UDV total, parcial ou sem deficiência, não podendo ser utilizado duas interfaces para fazer o controle domótico.

4. O aplicativo foi desenvolvido nas melhores práticas de acessibilidade visando atender as requisições mais pertinentes durante os pré-testes.

5. O aplicativo está configurado para funcionar em um sistema operacional Android, caso o usuário mude o sistema operacional utilizado por seu dispositivo móvel, será necessária a contratação de uma empresa especializada em desenvolvimento de software para a nova plataforma.

6. Pode haver atualizações no software de controle. Essas atualizações podem solicitar a visita de um técnico ou de uma pessoa especializada para os devidos ajustes e isso não está isento de custos.

Caso seja necessária a implantação de uma nova funcionalidade dentro do aplicativo como, por exemplo, atender aos usuários deficientes auditivos, o usuário poderá requerer um módulo para deficiente auditivo que deverá seguir a API já estabelecida. Será utilizado o mesmo programa para acoplar as novas funcionalidades, o código é open source e estará disponível para possíveis modificações. 
7. Existe a possibilidade de manutenção periódica no sistema e essas também podem gerar custos;

8. Quanto maior a acessibilidade requerida pelo usuário, mais sensores e atuadores serão necessários, e assim, maior será o preço final do protótipo.

9. Usuários moradores de apartamentos ou casas alugadas devem ficar atentos às possibilidades de ajustes nas instalações do ambiente. Um sistema mais simples pode ser projetado, porém nem todas as funcionalidades poderão ser contempladas devido a obras necessárias do ambiente.

\subsubsection{Conclusões para o desenvolvimento da interface acessível - usuários do CEEDV}

Após o pré-teste realizado do CEEDV, pôde-se concluir que é possível o desenvolvimento de uma interface com acessibilidade sem que o fator econômico seja acrescido exponencialmente. Para que isso ocorra, é imprescindível que a fase de pré-projeto seja bem elaborada visando focar nas expectativas do usuário.

Outro fator importante a ser considerado é a fase inicial do projeto. Mesmo que o sistema não tenha como público alvo usuários com deficiência já se deve ter o cuidado de atender às diretrizes do $\mathrm{W} 3 \mathrm{C}$, que em nada influência no layout e/ou nas funcionalidades da aplicação, mas asseguram a usabilidade de todos os usuários, independente se esse possui ou não uma deficiência. A padronização do W3C está destinada a orientar os desenvolvedores para o uso de boas práticas que tornam a web acessível para todos.

Com o desenvolvimento dos protocolos e dos fóruns abertos a todos que queiram contribuir e ajudar a promover a evolução da W3C para assegurar sua interoperabilidade, a W3C pode se manter atual, permitindo que as boas práticas de acessibilidade sejam utilizadas nos sistemas.

As diretrizes do W3C devem ser incorporadas na fase do projeto a ponto de se tornar algo transparente e natural em todos os desenvolvimentos de sistemas. Ao atribuir as contribuições dos pré-testes que observa o design emocional do usuário, pode-se desenvolver um sistema voltado ao usuário. A proposta desse trabalho é de uma interface acessível para um ambiente domótico, que passou por todas estas fases, terminando e sendo aprovado na fase de teste. 


\subsection{Conclusões a respeitos dos testes feitos com o aplicativo e o protótipo.}

Durante os testes realizados após o implante da interface, foi possível verificar que as normas e diretrizes do $\mathrm{W} 3 \mathrm{C}$ funcionam nos quesitos de acessibilidade e usabilidade. O teste comprovou a importância da opinião do usuário para os ajustes finais. Apesar de que o design visceral pode variar conforme a deficiência do usuário. Com a ajuda dos pré-teste antes da implantação e os testes finais após execução da interface a validação do usuário pode chegar a ser mais de $95 \%$ para todos os públicos.

No caso em questão, visou-se abranger o maior número de requisitos abordados durante o pré-teste. Isso levou o usuário a se sentir confortável, tendo acessibilidade com a interface e facilitando o controle e acionamento do ambiente de forma fácil e segura.

Durante os testes foi possível identificar os possíveis ajustes para que a o aplicativo tenha o máximo de acessibilidade. Ficou claro que o uso das normas do W3C no projeto é um facilitador que atende mais de $80 \%$ do quesito de acessibilidade necessário para que um usuário com deficiência possa utilizar o sistema. Os pré-testes nortearam o uso das diretrizes do W3C de forma a gerar conforto e acessibilidade no método aplicado.

De acordo com as colocações dos usuários sobre a melhoria da interface do HA, enfatizou-se que a acessibilidade do aplicativo não foi afetada, e que todas as melhorias se referiam à disposição dos itens na tela.

Por fim, foi possível comprovar a importância de:

1. Conhecer a necessidade do usuário utilizando as técnicas mencionadas durante a execução do método proposto;

2. Utilizar linguagem simples com o usuário e na implantação da interface;

3. Não exigir esforço do usuário para realizar tarefas simples;

4. Organizar as informações de forma clara e lógica;

5. Ter informações suficientes para que o usuário tenha o entendimento da solicitação;

6. Utilizar as regras do $\mathrm{W} 3 \mathrm{C}$ de gerência de layout;

7. Permitir que o usuário possa configurar o sistema de forma personalizada. 


\subsection{Trabalhos futuros}

Dentre os trabalhos futuros incluem-se:

- Realizar novos testes com UDV total e incluir os testes com os UDV parciais.

- Implantar as funções do menu secundário "Mais Configurações".

- Utilizar o método adoptado para a criação do aplicativo em outros sistemas operacionais.

- Utilizar o método adoptado para a criação de outras funcionalidades, incluindo novas deficiências. 


\section{REFERÊNCIAS}

A. king, G. Evans and P. Blenklorn, WebbIE: a Web Browser for Visually Impaired People, 2004.

ABNT - Associação Brasileira de Normas Técnicas. Guia para utilização das normas sobre avaliação de qualidade de software-ISSO/IEC 9126 E ISSO/IEC14598. Curitiba, 1999.

ADLIN, Tamara. The Persona Lifecycle: Keeping People in Mind Throughout Product Design. The Morgan Kaufmann Series in Interactive Technologies. Elsevier Science \& Technology, 2006.

ALMEIDA, R. A tecnologia por trás da mágica. Novembro 2009. Disponível em: $<$ http://quicaze.com/126/atecnologia-por-tras-da-magica/>. Acesso em: 16 de julho de 2016.

ANDROID, G. Android. 2013. Disponível em: 〈http://www.android.com >. Acesso em: 9 de fevereiro de 2016.

ANGEL, Patrícia Marta; FRAIGI, Liliana Beatriz. Introducion a la domotica. Córdoba: Embasse: EBAI, 1993. 171 p.

- NBR 9241-11 - Requisitos Ergonômicos para Trabalho de Escritórios com Computadores Parte 11 - Orientações sobre Usabilidade. Rio de Janeiro, 2002.

. NBR ISSO/IEC 9126-1 Engenharia de software - Qualidade de produto Parte 1: Modelo de qualidade. Rio de Janeiro, 2003.

ARAUJO, Regina Borges. Computação Ubíqua: Princípios, Tecnologias e Desafios. Universidade Federal de São Carlos- UFSCar, São Carlos - SP, 2003.

BARBETTA, P. A. Estatística aplicada às Ciências Sociais. 3.ed. Florianópolis: Ed. da UFSC, 1999.

BARBOSA, S.D.J.; SILVA, B.S. Interação Humano-Computador. São Paulo: CampusElsevier, 2010.

BARANAUSKAS, M. C. C.; DE SOUZA, C. S. Desafio 4: Acesso participativo e universal do cidadão brasileiro ao conhecimento. Computação Brasil, Porto Alegre, v. 23, p. 7-7, Set./Out. 2006.BRASIL. Lei no 10.098, de 19 de dezembro de 2000. Coleção de leis da República Federativa do Brasil, Brasília, DF, dez 2000.

BOGDAN, R. S.; BIKEN, S. Investigação qualitativa em educação: uma introdução à teoria e aos métodos. 12.ed. Porto: Porto, 2003.

BOLZANI, Caio Augustus Morais. Residências Inteligentes. $1^{\circ}$ Edição. São Paulo: Livraria da Física. 2004.

BRASIL. Casa Civil da Presidência da República. Decreto nº 6.949, de 25 de agosto de 2009.

BRASIL. Casa Civil da Presidência da República, Subchefia para Assuntos Jurídicos, decreto $\mathrm{N}^{\circ} 3.298$, de 20 de dezembro de 1999.

CACCIOPO, J.; GARDNER, W. Emotion. Annual Review of Psychology, 1999.

CALDEIRA, Laura Maria Mello Saraiva. Análises de Riscos em Geotecnia: Aplicação a barragens de aterro. 2005. 248 f. Dissertação (Doutorado) - Universidade Técnica de Lisboa - Instituto Superior Técnico, Lisboa, 2005.

CARD, S., Moran, T. et Newell, A. The Psychology of human computer interaction. Hilglade N.J. Lawrence Erbaum, 1983. 
CAREY, Jane m (Editor). Human Factors en Management Information Sistems. New jersey, Ablex publishing. ISBN 0-89391-448-7, 1988.

CARROLL, John M. "Designing Interaction". Psychology at the Human-Computer Interface. Cambridge Series on Human-Computer Interaction. Cambridge University Press, 1991.

CASADOMO. Domótica - Introducción. Agosto 2010. Disponível em:< https://www.casadomo.com>. Acesso em: 16 de julho de 2016.

CASELLI, Brígida. Acesso à informação digital por portadores de necessidades especiais visuais: estudo de caso Telecentro Acessível de Taguatinga. 2007. 94 f. Dissertação (Mestrado em Ciência da Informação) - Programa de Pós-graduação em Ciência da Informação e Documentação, Universidade de Brasília, Brasília, 2007.

CONNELL, B. R., JONES, M., MACE, R. et al. About UD: Universal Design Principles. Version 2.0. Raleigh: The Center for Universal Design, 1997.

COOPER A. The Inmates Are Running the Asylum: Why High-Tech Products Drive Us Crazy and How to Restore the Sanity. Indianapolis, Ind.: Sams, 1999.

CRAVEN, J. Access to electronic resources by visually impaired people. Information Research, 8(4), 454, 2003.

GRUDIN, J. e PRUITT, J. Personas. Participatory design and product development: an infrastructure for engagement, 2002.

CUNHA, Murilo Bastos DA - Metodologias para estudo dos usuários de informação científica e tecnológica,1982.

CYBIS, W.; BETIOL, A. H.; FAUST, R. Ergonomia e Usabilidade: Conhecimentos, Métodos e Aplicações. São Paulo: Novatec, 2007.

DEBAR, H., Marc Dacier e Andreas Wespi. Towards a taxonomy of intrusion-detection systems. Computer Networks, 1999(31): p. 805-822.

DECRETO Nº 5.296 DE 2 DE DEZEMBRO DE 2004.

DEMIR, E.; DESMET, P.; HEKKERT, P. Appraisal Patterns of Emotions in Human-Product Interaction. International Journal of Design, 3(2):41-51, 2009.

DEMO, P. Avaliação qualitativa. 7.ed. Campinas: Autores Associados, 2002.

DIAS, C. Usabilidade na web: criando portais mais acessíveis. Rio de Janeiro: Alta Books, 2003. xvi, 296 p.

DRITSAS, D. Beyond X-10 The Future of Home Automation. Setembro 2010.

ECHELON CORPORATION. Introduction to the LonWorks® Platform. Disponível em: <http://www.echelon.com/support/documentation>. Acesso em: 16 de julho de 2016.

EUZÉBIO, M. V. D. M. DroidLar - Automação residencial através de um celular Androide. IFSC. São José, SC - Brasil, p. 58. 2011.

FAÇANHA, T. dos S. Rede de sensores sem o: Uma abordagem para detecção de falhas em sistemas elétricos, 2007.

GADBOIS, C. Les tâches interferentes, un problème caracteristique du travail hospitalier. Soins, no 26 (12), pp. 15-18, 1981.

GELATTI, G. P. (2002). “A framework for Building Engines for Games and Simulations”,

Proceedings of the 1st Brazilian Workshop in Games and Digital Entertainment.

GIL, Antonio C. Métodos e técnicas de pesquisa social. 5. ed. São Paulo: Atlas, 1999. 
GUIMARÃES, A. D. A.; SARAIVA, A. M. O Protocolo CAN: Entendendo e Implementando uma Rede de Comunicação Serial de Dados baseada no Barramento "Controller Area Network”. Universidade de São Paulo. São Paulo, SP - Brasil, p. 10. 2002.

GOMES FILHO, J, F. Design do Objeto. BasesConceituais.São Paulo: Escrituras, 2006.

ITS. Pesquisa Nacional de Tecnologia Assistiva. Revista Conhecimento - Ponte para a Vida, São Paulo, n.1-2, p.42-49, mar. 2007. Uma metodologia para o desenvolvimento de produtos mecatrônicos integrando engenharia de software e engenharia de produtos.

JACOBSON, Ivar. (1992) Object-oriented software engineering - A use case driven approach. Addison Wesley Publishing Company.

KUROSE, JAMES F.; ROSS, KEITH W. Computer Networking: A Top-Down Approach Featuring the Internet. Addison Wesley Longman. 2000.

L. Nielsen, "Engaging Personas and Narrative Scenarios," Copenhagen, Denmark: Department of Informatics, Copenhagen Business School, 2004

LAVILLE, C.; DIONNE, J. A construção do saber: manual de metodologia da pesquisa em ciências humanas. Belo Horizonte: UFMG, 1999.

LUGLI, Alexandre Baratella; SOBRINHO, Darlan Guilherme: Tecnologias Eireless para Automação Industrial: Wireless_Hart, Bluetooth, Wisa, Wi-Fi, Zigbee e SP-100.

LACOMBE, F. J. M. Dicionário de administração. [S.I]: saraiva, 2004.

M. Satyanarayanan. Fundamental Challenges in Mobile Computing. In 15th ACM Symposium on Principles of Distributed Computing, p. 1-7, Springer-Verlag, 1996.

MAIA, J. G. R.; Cavalcante-Neto, J. B. e Vidal, C. A. (2003). “CRAbGE: Um Motor

Gráfico Customizável, Expansível e Portável Para Aplicações de Realidade Virtual”.

Proceedings of the 6th Symposium on Virtual Reality, pp.3-14, Ribeirão Preto, SP -

Brazil, 12-15.

MALHOTRA, N. Pesquisa de marketing. 3.ed. Porto Alegre: Bookman, 2001.

MANDURANO Justin and HABER Nicholas, House Away - A Home Management System, 2012.

MCGOOKIM David, Brewster Stephen, Jiang WeiWei, Investigating Touchscreen Accessibility for People with Visual Impairments, 2008.

MCMILLAN Scott; GUCCIONE, Steven A. Partial Run-Time Reconfiguration Using JRTR.

In: Proceedings Of Field Programmable Logic And Applications, Glasgow, Escócia, 1999.

MORAN, T. The Command Language Grammars: A Representation for the User Interface of Interactive Computer System. Internation Journal of Machine Studies, [S.1], n.15, p.3-50, 1981.

MOREIRA, D. A. O método fenomenológico na pesquisa. São Paulo: Pioneira Thompson, 2002.

MORIMOTO, C. E. Smartphones guia prático. [S.1.], 2009.

MURATORE J. Roberto, BÓ P. H. Dal Automação residencial: histórico, definições e conceitos, capítulo I, 2011.

NASCIMENTO A. C. Richter do Guia de referência para o desenvolvimento de produtos para portadores de deficiencia visual UIA, 2013 
NORMAN, D. Emotional design: Why we love (or hate) everyday things. New York, Basic Books, 272 p., 2004.

NÓBREGA, Carlos Lenine de Oliveira. Um Framework de Elaboração de Persona Empresa para Suporte na Análise de Valor de Negócio na Aplicação em Sistemas de Redes Sociais. Universidade de Fortaleza, Fortaleza, 2011.

PETRIE, H., Hamilton, F., King, N. \& PavanP. - Remote usability evaluations With disabled people - Proceedings of the SIGCHI conference on Human Factors in computing systems. Canada , 2006.

PINHEIRO, José Maurício Santos. Falando de Automação Predial. 2004. Disponível em: $<$ http://www.projetoderedes.com.br/artigos/artigo_falando_de_automacao_predial.php

PRATES, R. O. ; BARBOSA, S. D. J. Avaliação de Interfaces de Usuário - Conceitos e Métodos. In: XIX Congresso da Sociedade Brasileira de Computação, 2003. Anais da Jornada de Atualização em Informática. SBC, 2003.

PREECE, Jennifer, ROGERS, Yvonne, \& SHARP,Helen. Design de Interação: além da interaçãohomem-computador. Porto Alegre: Bookman, 2005.

RICHARDSON, R. J. Pesquisa social: métodos e técnicas. 3. ed. São Paulo: Atlas, 1999.

ROCHA, Heloisa Vieira da; BARANAUSKAS, Maria Cecília Calani (2003). "Design e avaliação de interfaces humano-computador”. Campinas, SP: NIED/UNICAMP, 2003.

SANTOS, V. A. A intensificação do trabalho nas Centrais de Atendimento. As múltiplas tarefas e atividades interferentes. 2002

SOUSA, R. de. CAN (Controller Area Network): uma abordagem para automação e controle na área Agrícola. 83 p. Mestrado - Escola de Engenharia de São Carlos

Universidade de São Paulo, 2002.

STEFANOV H. Dimitar, BIEN Zeungnam and BANG Won-Chul, The Smart House for Older Persons and Persons With Physical Disabilities: Structure, Technology Arrangements, and Perspectives, 2004.

SYLVANIA HOME AUTOMATION. Z-Wave Lighting and Appliance Control System Manual. 2005. Disponível em: 〈http://www.unical-usa.com>. Acesso em: 16 de julho de 2016.

TAKAGI, H., Asakawa, C., Fukuda K. \& Maeda J.: Accessibility designer: visualizing usability for the blind - ACM SIGACCESS Conference on Assistive Technologies Proceedings of the ACM SIGACCESS conference on Computers and accessibility, 2004.

TOBIN, J. C. "A study of library use studies". Information Storage and Retrieval, 1974.

TONETTO, L. Miletto, COSTA, F. C. Xavier da (2011). "Design Emocional: conceitos, abordagens e perspectivas de pesquisa". Strategic Design Research Journal, volume 4, number 3, September-December 2011

TANENBAUM, A. S. Rede de Computadores. [S.1.]: Editora Campus, 2003.

TORRES, Gabriel. Redes de computadores: curso completo. Rio de Janeiro: Axel Books, 2001

WEISER M.; , "The computer for the 21st Century," Scientifc American, vol.265, no.3, pp.94-104, March 1991.

Z-WAVE. Z-Wave. Disponível em: < http://www.flexautomation.com.br>. Acesso em: 16 de julho de 2016. 
APÊNDICE A - Manual de instruções.

Home Affortable

"Pensando na sua acessibilidade, ligando você ao mundo."

\section{Índice}

- Sobre o projeto de automação residencial para deficiente visual.

- Instalação e configuração do sistema.

- O aplicativo.

- Instruções das telas

A tela principal

A tela de controle de luzes

A tela de controle de luz por voz

A tela de controle de Acesso

A tela de Configurações do aplicativo

A tela mais configurações

A tela manual de instruções

\section{Manual de Instruções}

Home Affortable é uma central de automação sem fio feita para controlar ambientes residenciais e prediais pelo aplicativo HA. A central é controlada por meio de dispositivos móveis que propicia ao usuário acessibilidade, conforto e segurança.

Utilizando equipamentos com preço acessível, a Home Affortable é um projeto acadêmico que visa atender aos usuários de diferentes rendas familiares assim como incluir os UDV, por ter como controle da central um aplicativo que segue as diretrizes de acessibilidade além de ter uma interface de fácil manuseio, mecanismos de resposta rápida e que obedecem às recomendações da $\mathrm{W} 3 \mathrm{C}$.

Compatível com uma grande variedade de equipamentos, a central possibilita adequar a realidade dos usuários e proporcionar um cotidiano mais confortável. A acessibilidade, 
segurança e simplicidade no uso são pilares fundamentais do sistema, permitindo que os UDV parcial ou total sejam contemplados com os benefícios da Domótica.

Para que os ambientes estejam aptos a serem controlados pelo aplicativo HA e funcione plenamente, é necessário que o usuário tenha instalado em sua casa ou prédio a central de automação que é composta pela placa micro controlada Arduino Mega 2560 o Shild Ethernet, os atuadores e sensores específicos para cada automação. É importante frisar que o uso da internet compartilhada no ambiente por WiFi é indispensável para o funcionamento do sistema.

\section{Instalação e configuração do sistema}

A seguir as imagens referentes à central de automação. A figura 1 Placa micro controlada Arduino 2560 e a figura 2 o módulo Ethernet.

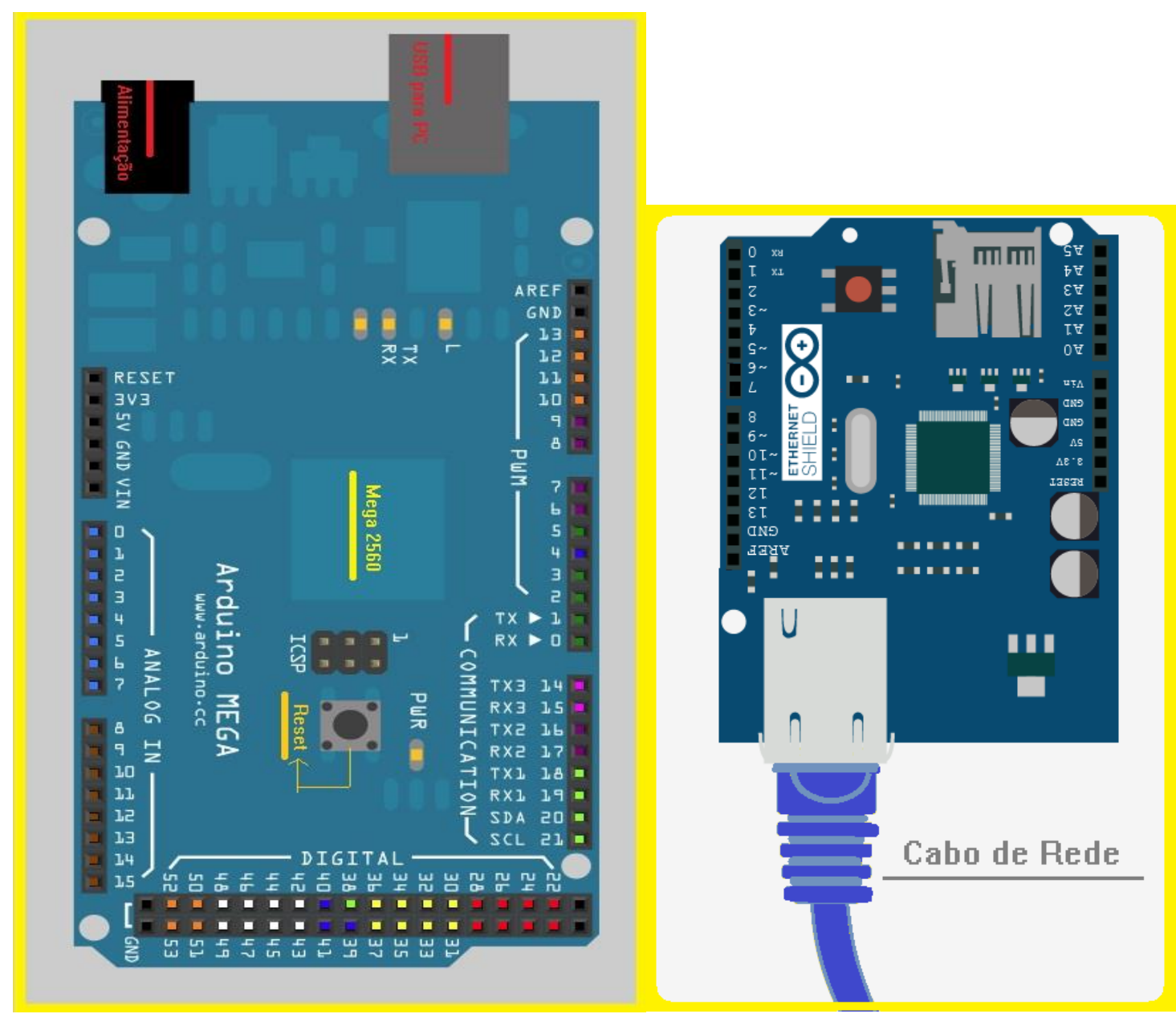

Figura -1 Placa micro controlada Arduino 2560 Figura -2 Shield Ethernet 
A placa micro controlada Arduino 2560 e o Shield Ethernet deverão estar devidamente configuradas e instaladas por um técnico que deverá ser contratado pelo usuário, isso gera um custo para o usuário que deverá escolher quais aplicações deseja automatizar e assim ter o orçamento do projeto feito pelo técnico.

\section{O aplicativo}

O aplicativo HA está disponibilizado para download, sem custos adicionais para o usuário. Para poder utilizar o aplicativo o usuário deverá ter em seu dispositivo móvel o sistema operacional Android com versão mínima de 4.0 e que contenha a função NFC - Near Field Communication. É importante frisar que as configurações do dispositivo irão contribuir com o bom funcionamento da central de automação e do aplicativo. A NFC é uma tecnologia que permite o reconhecimento entre dispositivos a uma curta distância sem precisar de qualquer tipo de cabo. Para os UDV é necessário que o dispositivo possua previamente configurar a função TalkBack que implementa respostas faladas, audíveis e por vibração ao dispositivo.

\section{Instruções das telas}

\section{A tela principal}

A tela principal dá acesso a todos os controles possíveis do aplicativo. Nela, está contido o menu principal que possui seis botões: Luzes, Acesso, Configurar, Manual, Sair e Instrução. A figura 3 mostra a disposição dos botões na tela.

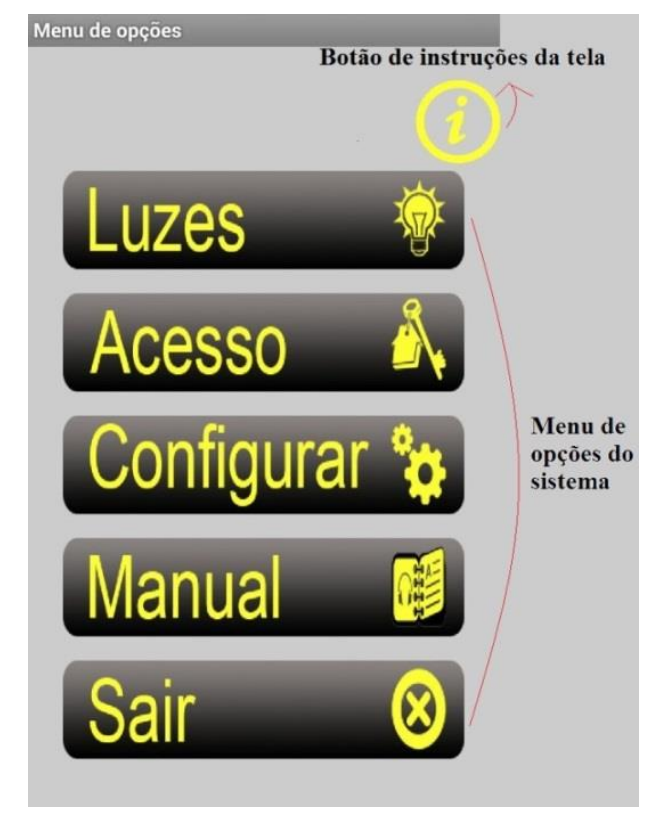

Figura 3- Tela principal 
Botão $i$ - Instruções da tela - Quando pressionado, o botão instrução traz as principais instruções da tela principal.

Botão Luzes - controle das luzes - Quando pressionado, o botão luzes abre a tela de controle das luzes da casa.

Botão Acesso - tela de acesso a casa - Quando pressionado, o botão acesso abre a tela de controle de acesso ao portão da casa.

Botão Configuração - configurações do aplicativo - Quando pressionado, o botão configuração abre a tela de configurações do aplicativo.

Botão Instruções - instruções - Quando pressionado, o botão instruções abre a tela do manual do aplicativo.

Botão Sair - sair do aplicativo - Quando pressionado, o botão sair fecha o aplicativo.

\section{A tela de controle de luzes}

A tela de controle de luzes contém, além do botão de "instruções da tela", todas as possibilidades de acionamento das luzes da sala, luzes do quarto, luzes da cozinha e luzes do banheiro. A cada cômodo é dada a opção de acionamento de até cinco luzes simultaneamente, que podem ser configuradas por meio de caixas de seleção. Nessa tela, também é possível o acionamento de todas as luzes de todos os cômodos por meio do botão "ligar todas as luzes". Também é possível o acionamento das luzes da residência por meio do botão "comando de voz”. No canto inferior da tela é possível voltar à tela anterior ou avançar. A figura 4 mostra a disposição dos botões da tela de controle de luzes. 


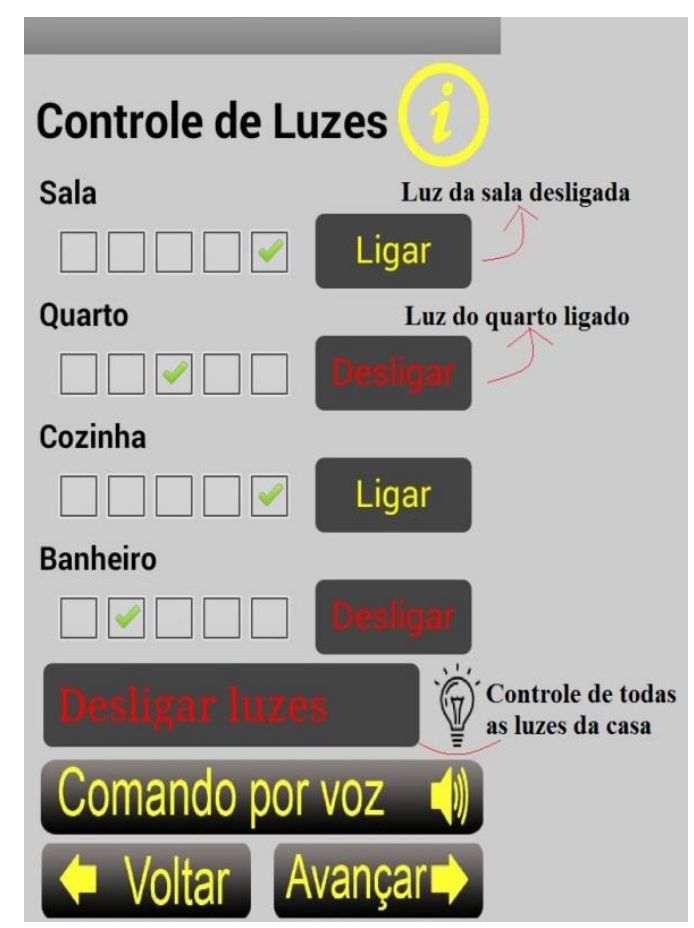

Figura 4 - Controle de Luzes

\section{A tela de controle de luz por voz}

A tela de controle de luzes pelo acionamento da voz, além do botão de "instruções da tela", possibilita o acionamento das luzes pela voz do usuário. Caso o "Google" não consiga entender o seu acionamento é possível tocar novamente no botão "toque para falar" e acionar o Google Now. Para acionar uma ou mais lâmpadas, é necessário que o usuário utilize a expressão "Ligar" seguido do nome do cômodo que deseja acionar a lâmpada, por exemplo, o usuário deseja ligar a luz da cozinha, então ele deverá falar: "Ligar cozinha". Ao falar o comando a luz da cozinha será acionada e no visor do dispositivo móvel estará escrito o que o usuário escreveu, no caso: "Ligar cozinha", caso o Google Now tenha entendido outra expressão estará escrito no dispositivo a expressão referente para ser conferida pelo usuário. Para os usuários que utilizam a função TalkBack não precisam se preocupar, pois o módulo de acessibilidade pode ler essa informação. Isso pode evitar possíveis erros, pois algumas vezes o Google Now entende de forma equivocada o que foi falado, por isso é sugerido que se fale alto e claro, utilizando a velocidade moderada da voz.

A Figura 5 mostra a disposição dos ícones na tela do controle por voz. 


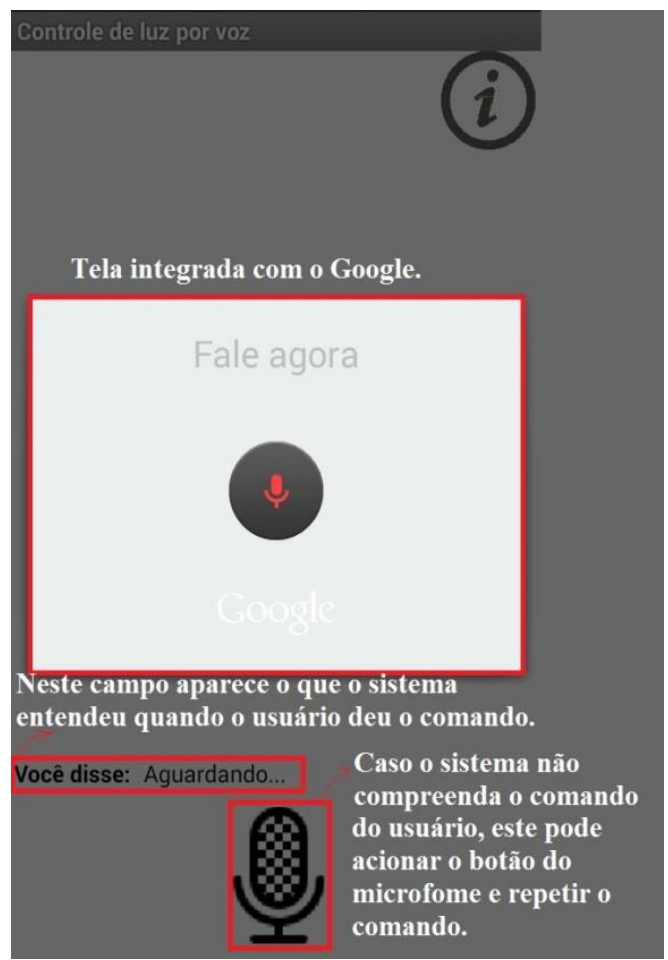

Figura 5 - Controle por voz

\section{A tela de controle de Acesso}

A tela de controle de acesso, além do botão de "instruções da tela", possibilita o acionamento do portão da casa por meio do cartão de acesso previamente configurado na tela de "configurações". Para que o sistema funcione perfeitamente é necessário que o cartão e o celular utilizado pelo usuário contenham o sistema de NFS. Quando o usuário clica no botão "código" é aberto o dispositivo de scanner e caso o código de acesso seja o cadastrado, o portão é acionado. No canto inferior da tela é possível voltar à tela anterior, avançar ou voltar à tela principal.

\section{A tela de Configurações do aplicativo}

A tela de configurações do aplicativo, além do botão de "instruções da tela", contém todas as configurações necessárias para o bom funcionamento do aplicativo e da central de automação. É possível configurar além do nome, da senha e do host da central o cadastro o código NFS que dá acesso ao controle do portão da residência.

O campo de on phone boot permite que uma vez salvo a senha no banco, o usuário não precise colocar novamente o login e senha a cada acesso no aplicativo. O campo que deve ser preenchido com o endereço de Rede/Host e é aconselhado que seja preenchido pelo técnico que irá instalar a central de automação, pois o endereço deve ser reservado. Caso um 
oportunista descubra o endereço de Rede/Host e tente acessar a residência via WEB - rede mundial de computadores, aparecerá para ele "Acesso negado" e caso o oportunista tente acessar o código fonte da página HTML - linguagem utilizada para desenvolver websites, não terá acesso a nenhuma informação sensível.

No canto inferior da tela é possível voltar à tela anterior, avançar ou voltar à tela principal assim como ter acesso às demais configurações do mecanismo de resposta ao usuário. A Figura 6 mostra a disposição dos ícones na tela de configuração.

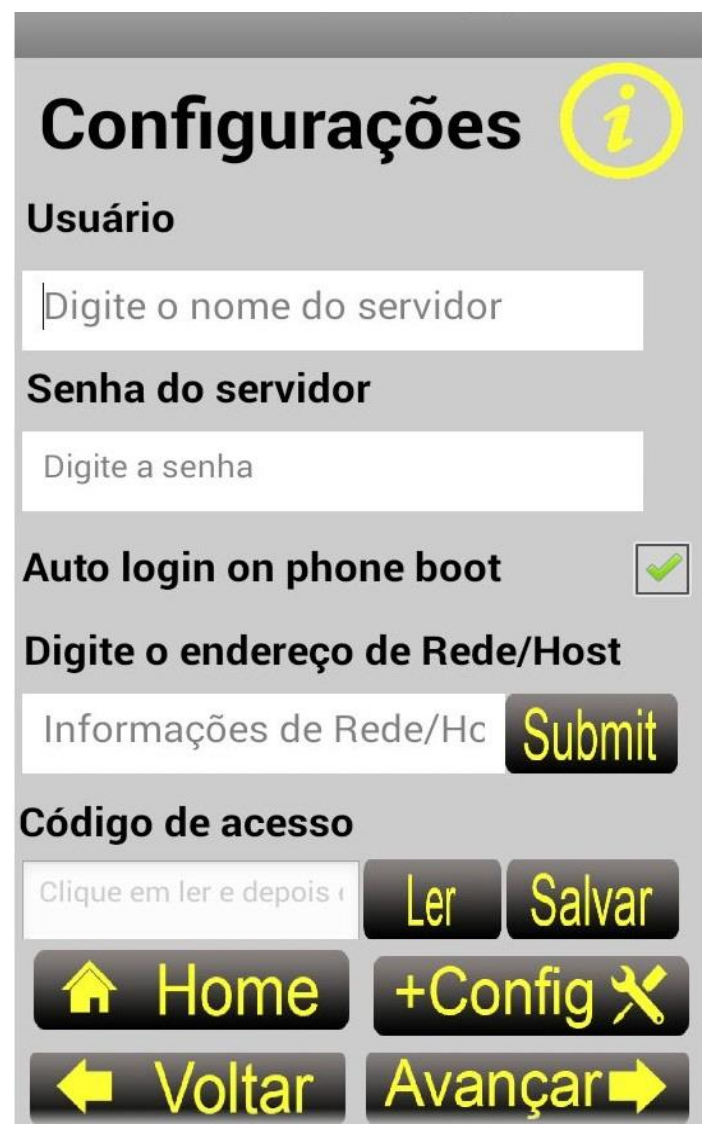

Figura 6 - Configurações do aplicativo

\section{A tela mais configurações}

A tela de mais configurações, além do botão de "instruções da tela", contém todas as configurações do mecanismo de resposta. Nessa tela há sete dispositivos de resposta ao usuário. Além de vibrar e do bip sonoro, existem outros mecanismos que podem ser escolhidos pelo usuário. Por padrão, o aplicativo vem com cinco mecanismos de resposta já configurados, esses podem ser desmarcados a gosto do usuário.

No canto inferior da tela é possível voltar à tela anterior, ou voltar à tela principal. 


\section{A tela manual de instruções}

A tela manual de informações contém o manual de todas as informações dispostas nesse aplicativo.

No canto inferior da tela é possível voltar à tela anterior ir à tela principal ou sair do aplicativo.

PS: Esse aplicativo pode conter mais funcionalidades de acordo com a necessidade do cliente. 
APÊNDICE B - Questionário.

\section{Questionário Informacional para Pesquisa de Mestrado:}

Pré-teste com Usuários com Deficiência Visual.

Dados do entrevistador:

Aluna: Mayra Batista Corrêa

Professor Orientador: Carlos Humberto Llanos

Local da pesquisa:

Local de realização da pesquisa: CEEDV

Centro de Ensino Especial 02, Módulo D - Sgas 612 - Asa Sul, Brasília - DF, 70200-710

Dados do entrevistado:

Nome do usuário: João da Silva

Idade:
( ) $18-20$
( ) $20-25$
( ) $25-30$
( x ) $30-40$
( ) acima de 40

\section{Grau de deficiência:}

(x ) Total

( ) Parcial

Usa algum corretor visual? ( )

( ) Congênita

(x) Adquirida

OBS: Perdeu com 16 anos de idade

\section{Transporte:}

Público ( $\mathrm{x}$ )

Privado ( )

OBS:

\section{Escolaridade:}

( ) Analfabeto

( ) Fundamental incompleto 

( ) Fundamental completo
( ) Médio incompleto
(x ) Médio completo
( ) Superior incompleto
( ) Superior completo

OBS: Escola inclusiva

\section{Trabalho:}

( $x$ ) $\operatorname{Sim}$

Público ( $\mathrm{x}$ )

Privado ( )

( ) Não

OBS: Auxiliar de Educação

\section{Habitação:}

Próprio ( $\mathrm{x}$ )

Alugado ( )

Casa ( $\mathrm{x}$ )

Apartamento ( )

Seu prédio tem acessibilidade?

Rampas ( )

Elevador com sinal sonoro ( )

Botoeiras e comandos acompanhados dos signos em Braille ( )

Tapetes táteis nos corredores do prédio ( )

Dentro de sua casa tem alguma acessibilidade que o auxilie?

( ) $\mathrm{Sim}$

( x ) Não

\section{OBS:}

Número de pessoas na habitação:

Mora sozinho ( )

( ) 1

( $x$ ) 2 - 5

( ) mais que 5 pessoas

OBS:

Na sua casa existem outras pessoas com deficiência visual? ( $x$ ) $\operatorname{Sim}$ 
( ) Não

OBS: Esposa deficiência visual (Adquirida aos 29 anos)

Uso de sistemas computacionais (computador):

Você possui computador em sua casa?

( $\mathrm{x}) \operatorname{Sim}$

Com internet ( $\mathrm{x}$ )

Sem internet ( )

( ) Não

Com software de leitura de texto?

( $\mathrm{x}) \operatorname{Sim}$

( ) Não

OBS: JAWS

Há quanto tempo você usa sistemas computacionais (computador)?

( ) Menos de 3 meses

( ) Entre 3 meses e 1 ano

( $\mathrm{x}$ ) Mais de 1 ano

Com que frequência você usa sistemas computacionais (computador)?

( $x$ ) Diariamente

( ) Ocasionalmente

( ) Algumas vezes por semana

( ) Algumas vezes por mês

Qual a plataforma computacional que você utiliza com mais frequência?

(x ) Windows 7
( ) Linux
( ) Outra

Qual o seu nível de conhecimento em Informática?

( ) Básico

( x ) Intermediário

( ) Avançado 


\section{Questionário a respeito do Pré-teste realizado com os Usuários com Deficiência Visual}

Você já havia acessado este sítio antes?

( $\mathrm{x}$ ) $\operatorname{sim}$

Com qual frequência?

( ) Sempre

( ) Nunca

( x ) Raramente

( ) não

Porque?

( ) Não me interesso pelo conteúdo

( ) Desconheço o domínio do sítio

( ) Sítio difícil, inacessível

OBS: Não acha acessível

Não se interessa pelo conteúdo

Uso do sítio na realização da tarefa.

( ) Muito fácil

( $\mathrm{x}$ ) Fácil

( ) Nem fácil nem difícil

( ) Difícil

( ) Muito difícil

Comunicação com o sítio nas ações em geral em relação à linguagem apresentada.

( ) Muito fácil

( x ) Fácil

( ) Nem fácil nem difícil

( ) Difícil

( ) Muito difícil

Uso da sequência de tabulação para localização no sítio.

( ) Muito fácil

( x ) Fácil

( ) Nem fácil nem difícil

( ) Difícil

( ) Muito difícil

Visualização das instruções e advertências do sítio. 

( ) Muito fácil
( ) Fácil
( ) Nem fácil nem difícil
( ) Difícil
( ) Muito difícil

Compreensão das instruções e advertências do sítio.
( ) Muito fácil
( ) Fácil
( ) Nem fácil nem difícil
( ) Difícil
( ) Muito difícil

Navegação pelas janelas de diálogo do sítio.
( ) Muito fácil
( x ) Fácil
( ) Nem fácil nem difícil
( ) Difícil
( ) Muito difícil

Recuperação de situações de erro.

Recuperação de situações de erro.
( ) Muito fácil
( ) Fácil
( ) Nem fácil nem difícil
( ) Difícil
( ) Muito difícil

Compreensão das mensagens de erro apresentadas.
( ) Muito fácil
( ) Fácil
( ) Nem fácil nem difícil
( ) Difícil
( ) Muito difícil 
Navegação por meio das diferentes opções do menu, janelas de diálogo e barras de ícones do sítio.

( $\mathrm{x}$ ) Muito fácil

( ) Fácil

( ) Nem fácil nem difícil

( ) Difícil

( ) Muito difícil

Compreensão da estruturação dos menus, barras de ícones ou listas de informações disponibilizadas pelo sítio.

( x ) Muito fácil

( ) Fácil

( ) Nem fácil nem difícil

( ) Difícil

( ) Muito difícil

Uso de um leitor de tela, o sítio se mostrou lento?

( ) $\operatorname{sim}$

( $\mathrm{x}$ ) não

OBS:

Usando um leitor de tela, o sítio se mostrou acessível?

( $\mathrm{x}) \operatorname{sim}$

( ) não

OBS:

O uso do contraste foi possível?

( ) $\operatorname{sim}$

( ) não

Usando o contraste, existiu pouco contraste entre o fundo e o texto do sítio?
( ) $\operatorname{sim}$
( ) não

OBS:

O tamanho da fonte foi muito pequeno, dificultando a leitura?

( ) $\operatorname{sim}$

( ) não 
O uso de pop-ups foram usados em exagero?

( ) $\operatorname{sim}$

( x ) não

As imagens utilizavam alt tags apropriadas?

( ) $\operatorname{sim}$

( x ) não

O uso de links dificultou a navegação pelo sítio?

( ) $\operatorname{sim}$

( x) não

O acesso do vídeo se tornou acessível, com legendas de diferentes tamanhos?

( ) $\operatorname{sim}$

( x ) não

OBS:

A tarefa solicitada foi concluída?

( $\mathrm{x}$ ) $\operatorname{sim}$

( ) não

OBS:

Uso do tout facilita a vida

Comando por voz essencial

OBS: Respostas verdadeiras

Personagem fictício. 